\title{
Argumentação e prova matemática na Educação Básica
}

André Rodrigues Rosale

\author{
DISSERTAÇÃO APRESENTADA \\ AO \\ INSTITUTO DE MATEMÁTICA E \\ ESTATÍSTICA \\ DA \\ UNIVERSIDADE DE SÃO PAULO \\ PARA \\ OBTENÇÃO DO TÍTULO \\ $\mathrm{DE}$ \\ MESTRE EM CIÊNCIAS
}

\begin{abstract}
Programa: Mestrado Profissional em Ensino de Matemática

Orientadora: Professora Doutora Martha Salerno Monteiro
\end{abstract}

São Paulo, fevereiro de 2018 


\section{Argumentação e prova matemática na Educação Básica}

Esta versão da dissertação contém as correções e alterações sugeridas pela Comissão Julgadora durante a defesa da versão original do trabalho, realizada em 15/12/2017. Uma cópia da versão original está disponível no Instituto de Matemática e Estatística da

Universidade de São Paulo.

Comissão Julgadora:

- Prof ${ }^{\text {a }}$. Dr ${ }^{\text {a }}$. Martha Salerno Monteiro (orientadora) - IME-USP

- Prof ${ }^{a}$. Dr ${ }^{a}$. Ana Paula Jahn - IME-USP

- Prof $^{\text {a }}$. Dr ${ }^{\text {a }}$. Monica Karrer - FEI 
Dedico este trabalho aos meus pais, Valdir Rosale e Maria do Carmo, e aos meus avós. 


\section{Agradecimentos}

Primeiramente, a todos os professores do Instituto Federal de Ciência e Tecnologia de São Paulo (IFSP) e da Universidade de São Paulo (USP) que foram e são fundamentais na formação do amor que tenho por trabalhar na área da Educação e pesquisar sobre Ensino de Matemática.

Sou especialmente grato à professora Doutora Martha Salerno Monteiro, pela sua orientação, paciência e dedicação à melhora de nosso trabalho.

Agradeço às professoras Ana Paula Jahn e Monica Karrer, membros da Comissão Julgadora, fundamentais no aprimoramento desta dissertação. Assim como ao professor Doutor Ruy Pietropaolo, presente no exame de qualificação deste trabalho, por diversas sugestões que contribuíram com a qualidade de nossa pesquisa.

À equipe de gestão, alunos e responsáveis, professores e demais funcionários da EMEF Sandro Luiz Braga, onde a pesquisa foi realizada.

A todos os meus alunos e amigos professores, pelo aprendizado em cada discussão e em cada dificuldade que enfrentamos juntos.

A todos os envolvidos no programa de Mestrado Profissional em Ensino de Matemática, do Instituto de Matemática e Estatística da Universidade de São Paulo.

Aos meus amigos de curso, que tanto me ensinaram desde o ingresso no curso de Licenciatura em Matemática em 2009.

Aos meus pais, Maria do Carmo e Valdir Rosale, que desde cedo incentivaram-me a estudar e buscar conhecimento, deram-me suporte em todas as minhas escolhas, além de um amor incondicional.

À minha avó, que me acompanha a cada passo da vida, e ao meu avô, que estará sempre em meus pensamentos.

Ao meu irmão Márcio, aos meus tios e tias, aos meus primos e, em especial, às minhas primas, Sabrina e Daiani, que são, na realidade, como verdadeiras irmãs.

À Manu, minha esposa/namorada/amiga, pelo incentivo, paciência e companheirismo em absolutamente tudo o que eu faço. 


\section{Resumo}

ROSALE, A. R. Argumentação e prova matemática na Educação Básica. 2017133 f. Dissertação (Mestrado) - Instituto de Matemática e Estatística, Universidade de São Paulo, São Paulo, 2017.

Neste trabalho, buscamos propor atividades e relacionar ações que o professor de Matemática pode adotar durante as aulas, com o objetivo de propiciar a melhora do nível de argumentação e prova de seus alunos da Educação Básica. Inicialmente, pesquisamos sobre as definições de prova sob a ótica do ensino de Matemática, em que concluímos que o desenvolvimento de argumentações e provas é fundamental para que os objetivos dos PCN sejam alcançados. Com análise das avaliações do PISA, notamos que, em geral, os estudantes brasileiros possuem baixo desempenho em relação as habilidades que envolvem generalizações e desenvolvimento de provas. Na tentativa de propor melhorias a esse cenário, acreditamos que o desenvolvimento de provas na Educação Básica não deve se restringir as demonstrações aceitas pela comunidade matemática. Para isso, o professor deve conhecer e aceitar os diversos tipos de provas apresentados por seus alunos. Nesse ponto, a formação do professor de Matemática é essencial. Por fim, desenvolvemos atividades e aplicamos em uma sala do 9o ano do Ensino Fundamental, o que possibilitou, após as análises, que realizássemos conclusões sobre as características das atividades que propiciam o desenvolvimento de provas e ações que possibilitam a melhora do nível de argumentação de nossos estudantes.

Palavras-chave: argumentação, prova, demonstração, Educação Básica, raciocínio. 



\section{Abstract}

ROSALE, A. R. Argumentation and proof on Basic School. 2017133 f. Dissertação (Mestrado) - Instituto de Matemática e Estatística, Universidade de São Paulo, São Paulo, 2017.

In this study e seek to propose activities and to relate actions that the Mathematics teacher can adopt during the classes, seeking to improve the level of argument and proof of his students of Middle and High School. Initially, we investigated the definitions of proof from the point of view of mathematics teaching, in which we concluded that the development of arguments and proofs is fundamental for the goals of PCN been achieved. With the analysis of the PISA assessments, we noticed that, in general, Brazilian students have poor performance in relation to the skills that involve generalizations and the development of proofs. In an attempt to propose improvements to this scenario, we believe that the development of proofs in Middle and High School should not be restricted to the demonstrations accepted by the mathematical community. About that, the teacher must know and accept the different types of proofs presented by his students. At this point, the courses to the Mathematics teachers, preservice and inservice, are essential. Finally, we developed activities and applied in a class of 9th grade students, which made it possible, after the analysis, to make conclusions about the characteristics of the activities that help to the development of proofs and actions that allow the improvement of argumentations level of our students.

Keywords: argumentation, proof, demonstration, reasoning. 



\section{Sumário}

Lista de Figuras $\quad$ xi

Lista de Tabelas $\quad$ xiii

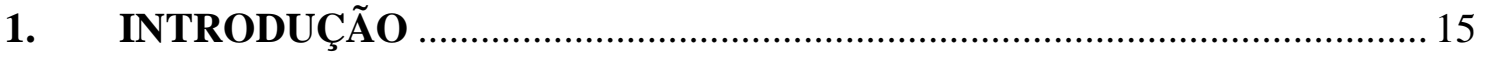

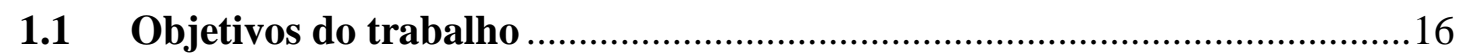

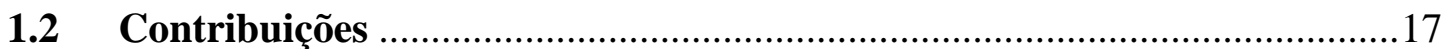

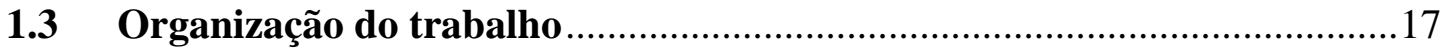

2. A PROVA NO CONTEXTO DA MATEMÁTICA ESCOLAR .................... 19

2.1 A prova no currículo da educação básica …...............................................27

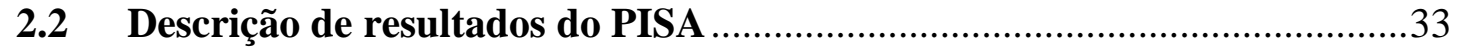

3. FUNÇÕES DA PROVA NA EDUCAÇÃO BÁSICA ..................................... 39

4. TIPOS DE PROVA NO CONTEXTO ESCOLAR …................................ 45

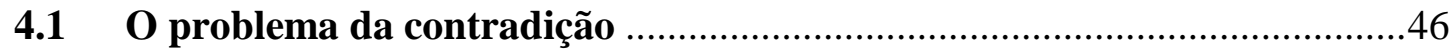

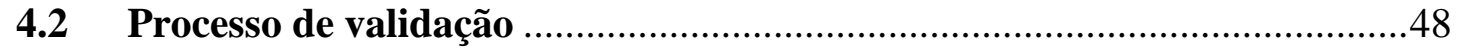

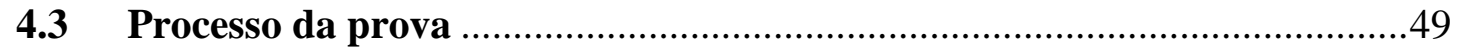

4.4 Das provas práticas às provas intelectuais …............................................

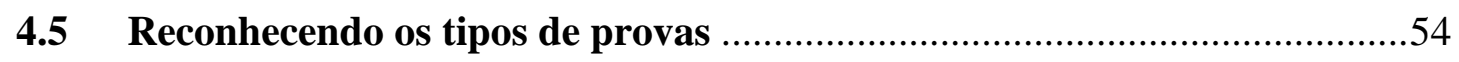

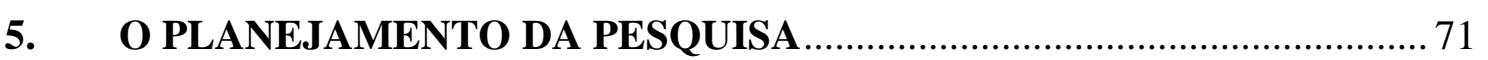

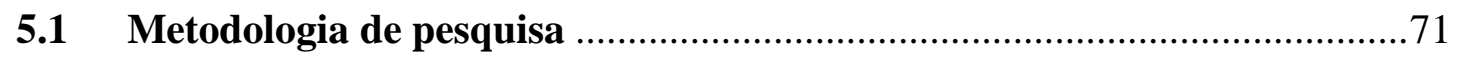

5.2 Escola escolhida para desenvolvimento das atividades ..............................73

5.3 Análise da base curricular e material didático ….......................................74

5.4 A importância da formação do professor ................................................... 84

6. A APLICAÇÃO DAS ATIVIDADES …................................................... 91

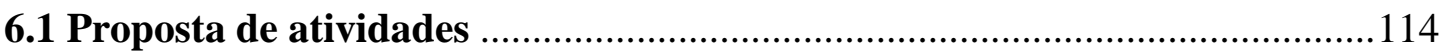

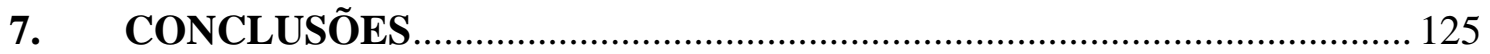

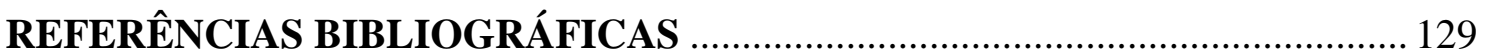

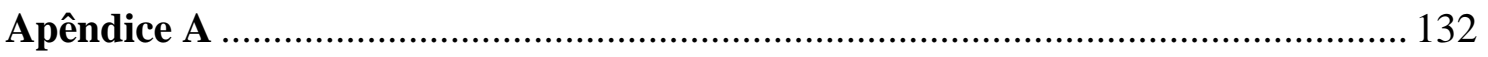

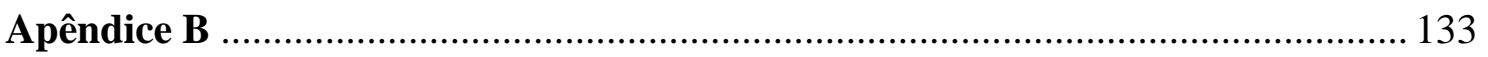





\section{Lista de Figuras}

FIGURA 1 - Descrição dos níveis de habilidades do PISA......................................................34

FIGURA 2 - Ranking dos países participantes do PISA 2006...............................................35

FIGURA 3 - Gráfico de comparação de resultados brasileiros entre o PISA 2003 e 2012...36

FIGURA 4 - Esquema de polos da passagem de provas proposto por Balacheff.....................54

FIGURA 5 - Esquemas de provas apresentados por Sowder e Harel....................................61

FIGURA 6 - Resposta do aluno A - Atividade 1 - diagnóstica - Questão 1..........................93

FIGURA 7 - Resposta do aluno B - Atividade 1 - diagnóstica - Questão 1............................93

FIGURA 8 - Resposta do aluno C - Atividade 1 - diagnóstica - Questão 1..........................94

FIGURA 9 - Resposta do aluno D - Atividade 1 - diagnóstica - Questão 1..........................95

FIGURA 10 - Resposta do aluno E - Atividade 1 - diagnóstica - Questão 1..........................96

FIGURA 11 - Resposta do aluno F - Atividade 1 - diagnóstica - Questão 2...........................98

FIGURA 12 - Resposta do aluno A - Atividade 1 - diagnóstica - Questão 3..........................99

FIGURA 13 - Resposta do aluno B - Atividade 1 - diagnóstica - Questão 3..........................99

FIGURA 14 - Resposta do aluno G - Atividade 1 - reaplicação - Questão 1........................103

FIGURA 15 - Resposta do aluno F - Atividade 1 - reaplicação - Questão 1.......................104

FIGURA 16 - Resposta do aluno F - Atividade 1 - diagnóstica - Questão 1..........................104

FIGURA 17 - Resposta do aluno E - Atividade 1 - reaplicação - Questão 1.......................105

FIGURA 18 - Resposta do aluno E - Atividade 2 2.......................................................108

FIGURA 19 - Resposta do aluno C - Atividade 3 ….......................................................112

FIGURA 20 - Resposta do aluno I - Atividade 3 ...........................................................112

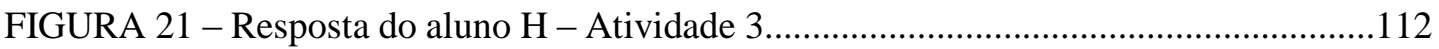




\section{Lista de Tabelas}

TABELA 1 - Pontuação dos níveis de habilidades do PISA..............................................34

TABELA 2 - Resultado do Pisa para estudantes brasileiros em 2003.............................35

TABELA 3 - Comparação entre as tipologias de prova....................................................67

TABELA 4 - Base curricular - Barueri - 9o ano - 2o trimestre de 2016.........................76

TABELA 5 - Tabulação - Atividade 1 - diagnóstica - Questão 1 ..................................97

TABELA 6 - Tabulação - Atividade 1 - diagnóstica - Questão 2..................................98

TABELA 7 - Tabulação - Atividade 1 - diagnóstica - Questão 3..................................100

TABELA 8 - Questão 1 - Comparação entre Atividade 1 e a reaplicação......................106

TABELA 9 - Questão 2 - Comparação entre Atividade 1 e a reaplicação.......................106

TABELA 10 - Questão 3 - Comparação entre Atividade 1 e a reaplicação.....................107

TABELA 11 - Tabulação - Atividade 2.......................................................................109

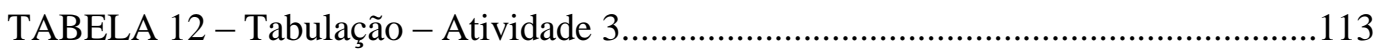




\section{Introdução}

Acreditamos que a argumentação matemática tenha grande influência na formação do aluno como futuro cidadão, capaz de compreender o mundo de modo mais profundo e crítico. Desde 2011 atuando na rede pública, tivemos a oportunidade de vivenciar várias situações, em assuntos voltados ou não à Matemática, em que a habilidade de argumentar foi necessária. Tivemos a rica experiência de observar diferentes tipos de argumentação de alunos que tentavam justificar as suas conclusões feitas na resolução de um determinado problema matemático, tanto argumentos muito bem formulados e embasados em teorias e linguagem matemática, quanto interessantíssimas justificativas utilizando pura e exclusivamente a língua materna. Por outro lado, a maior motivação para a realização do presente trabalho, é justamente o contrário do mencionado anteriormente: a dificuldade de muitos alunos em justificar o seu raciocínio, ou até mesmo seguir uma linha básica de argumentação.

Durante esses anos em sala de aula, notamos que diversos alunos têm extrema dificuldade em relação à argumentação matemática, principalmente quando tal é solicitada em uma linguagem formal. Trabalhamos desde o 6o ano do Ensino Fundamental até o $3^{\circ}$ ano do Ensino Médio e, independentemente de qual ano a argumentação matemática era observada, notávamos pouquíssima evolução ao longo do ano letivo. Também pudemos observar que muitos alunos não sentem necessidade de uma explicação lógica para a compreensão de certas relações e até preferem aceitar fórmulas e procedimentos sem explicação.

Nesse sentido, Nasser e Tinoco argumentam que:

Observa-se que nas séries iniciais a criança é mais espontânea e consegue explicar seu raciocínio oralmente, com naturalidade. Conforme os anos vão passando, essa espontaneidade diminui, e o aluno não consegue justificar suas soluções nem oralmente nem escrito. Portanto, a habilidade de argumentar deve ser trabalhada desde as primeiras séries, para que o aluno mais tarde seja capaz de defender um ponto de vista próprio, seja numa 
conversa informal, seja numa questão de matemática. (NASSER E TINOCO, 2003, p. 9)

Ao longo do tempo lecionando na Educação Básica, foi possível experimentarmos e analisarmos algumas situações didáticas envolvendo argumentação matemática e, assim, encontramos a possibilidade de um grande campo de pesquisa, em que podemos levar em consideração a vivência em sala de aula e, ao mesmo tempo, aprimorarmos tais situações didáticas que podem ser pensadas e testadas. É a busca incessante pela melhoria do ensino de Matemática e, em particular, da argumentação e prova que fez com que escolhêssemos esse tema para realização da dissertação de mestrado.

\subsection{Objetivos do trabalho}

\section{Objetivos gerais}

Neste trabalho estudamos o desenvolvimento da habilidade de argumentação e prova matemática para alunos da Educação Básica, na perspectiva da importância do tema para a formação plena do educando. Nosso objetivo é responder as perguntas:

- Como trabalhar as situações que envolvem a argumentação e prova matemática na Educação Básica?

- Quais os principais meios de desenvolvimento da habilidade de argumentação e prova matemática para alunos da Educação Básica?

É natural que ao decorrer do trabalho, novas perguntas sejam formuladas para complementar as questões iniciais.

\section{Objetivos específicos}

- Propor situações que favoreçam o desenvolvimento de argumentações.

- Analisar as produções de uma amostra de alunos do nono ano da Educação Básica na construção de argumentações matemáticas segundo as visões de Balacheff (1987), Sowder e Harel (1998), Rezende e Nasser (1994) e De Villiers (2001).

- Apresentar ações que os professores de Matemática podem adotar para que a atividade envolvendo argumentação faça parte da prática docente. Mostrar ao docente a possibilidade de avaliar as produções de prova de seus alunos com um 
olhar mais amplo, que vai além do aceito exclusivamente pela comunidade matemática.

\subsection{Contribuições}

Acreditamos que esse trabalho possa contribuir, principalmente para o professor que trabalha diretamente com a Educação Básica, com uma melhor compreensão com relação a provas realizadas pelos seus alunos.

Esperamos também que possamos contribuir com o professor de Matemática, quanto ao critério de escolha de atividades que contemplem o desenvolvimento de habilidades envolvendo argumentação e prova matemática para os alunos da Educação Básica.

Este trabalho conta com análises e comentários não apenas sobre resultados obtidos, mas também sobre o desenvolvimento das atividades, nossas principais dificuldades, os motivos das escolhas feitas ao decorrer da pesquisa, e principalmente explicações de como conseguimos superar os obstáculos pertinentes ao cotidiano de todo professor que se sujeita a trabalhar com relevância o tema abordado, de modo que possamos auxiliar outros professores com a questão da argumentação e prova matemática por seus alunos.

\subsection{Organização do trabalho}

Organizamos este trabalho em 7 capítulos, incluindo esta introdução.

No Capítulo 2 fazemos um estudo sobre argumentação matemática e a sua importância na formação do estudante na Educação Básica. Apresentamos os últimos resultados do Brasil nos PISA (Programme for international student), com o objetivo de obter um diagnóstico sobre a atual situação do ensino de Matemática, e em particular de prova matemática em nosso país. Em seguida, estudamos quais pontos dos PCN (Parâmetros Curriculares Nacionais) abordam temas ligados a argumentação e prova matemática.

No Capítulo 3 abordamos as principais funções da prova matemática, principalmente do ponto de vista de De Villiers (1990, 1991 e 2001).

No Capítulo 4 apresentamos nossas referências bibliográficas para as análises das provas realizadas por nossos estudantes, em que buscamos a compreensão quanto ao desenvolvimento do raciocínio do aluno segundo a prova matemática apresentada. 
A organização, as características da escola, da comunidade e dos alunos que fizeram parte de nossa pesquisa, e análise do material didático são apresentados no Capítulo 5, onde também mencionamos a metodologia selecionada para realizar a pesquisa diretamente com os estudantes.

Toda a investigação de campo está disponível no Capítulo 6, em que apresentamos as análises de 3 atividades aplicadas para alunos de 9o ano de uma escola municipal de Barueri, além de propor atividades que acreditamos possibilitar a melhora do nível de argumentação e prova por parte de nossos alunos.

Por fim, no capítulo 7, realizamos as considerações finais e planejamos atividades que certamente farão parte de nossa vida acadêmica ou profissional. 


\section{A prova no contexto da matemática escolar}

O desenvolvimento, pelo aluno, da capacidade de argumentação e prova matemática é estudado com a intenção de contribuir com a formação do estudante, para que se torne um cidadão capaz de se expressar de forma adequada, fazer argumentações convincentes e corretas, ser crítico em relação à informações apresentadas, descobrir padrões, e saber escolher meios adequados de confirmação de resultados que lhe sejam importantes.

É fato que argumentações, provas e demonstrações formais bem consistentes são de importância fundamental para matemáticos. Nesse sentido, vale à pena considerar o que Charnay (2001) afirma sobre os significados dos conteúdos matemáticos: o autor diz que há um significado interno muito evidente, coerente e convincente, que trata de questões voltadas propriamente para a linguagem matemática (propriedades, teoremas). Por outro lado, considerando a relação entre o ensino de Matemática e os alunos da Educação Básica, o principal objetivo é contribuir para a formação do cidadão. É nesse ponto que a argumentação e prova assumem significados externos, em que, segundo Charnay, podemos reconhecer campos de utilização desse conhecimento, como já assinalam os PCN:

O ensino de Matemática prestará sua contribuição à medida que forem
exploradas metodologias que priorizem a criação de estratégias, a
comprovação, a justificativa, a argumentação, o espírito crítico, e favoreçam
a criatividade, o trabalho coletivo, a iniciativa pessoal e a autonomia advinda
do desenvolvimento da confiança na própria capacidade de conhecer e
enfrentar desafios (BRASIL, 1998, p. 26).

Levando em consideração os documentos que norteiam o ensino de Matemática no país, apresentamos, ao longo do trabalho, pesquisas que convergem para a importância da argumentação e prova matemática na formação do cidadão. Todas as conclusões, e quaisquer propostas apresentadas neste trabalho, têm como "norte" facilitar a relação da argumentação e prova matemática com a sua função explicitada nos PCN brasileiros. 
Nos baseamos no forte elo entre a aprendizagem no campo da Matemática, mais precisamente da argumentação e prova matemática, e o desenvolvimento do raciocínio lógico. Para tanto, vamos utilizar o termo "raciocínio" como Balacheff (1987) que preserva a palavra em seu trabalho para designar a atividade intelectual, a maior parte do tempo não explícita, de manipulação de informações para, a partir de informações conhecidas, produzir novas informações. No mesmo sentido, Maritain diz que:

Raciocinar é passar de uma coisa intelectualmente aprendida a uma outra coisa intelectualmente aprendida graças à primeira, e progredir deste modo de proposição em proposição a fim de conhecer a verdade inteligível. (MARITAIN, 2001, p. 173)

É importante enfatizarmos o raciocínio lógico dedutivo e o raciocínio lógico indutivo, por estarem ambos diretamente ligados as ideias de argumentação matemática.

Para Maritain, o raciocínio dedutivo ocorre quando:

Nosso espírito pode mover-se partindo dos princípios universais conhecidos imediatamente pela inteligência, ligando a esses princípios uma conclusão ou resolvendo-a. (...). (MARITAIN, 2001, p. 186)

Maritain (2001) diz que no raciocínio dedutivo, a partir de uma primeira informação que sabemos ser verdadeira, o antecedente, podemos reconhecer uma outra informação, o consequente, como algo verdadeiro e, o raciocínio e argumentação são empregadas, às vezes, no mesmo sentido. $\mathrm{O}$ autor define argumentação como o organismo lógico formado pelo antecedente (parte motora) e pelo consequente (parte causada).

Por exemplo:

- Todo múltiplo de 4 é par;

O número 316 é múltiplo de 4;

Logo, o número 316 é par.

Nesse exemplo de raciocínio dedutivo ou argumentação dedutiva podemos observar que a proposição Todo múltiplo de 4 é par (antecedente) e a conclusão de que o número 316 é par (consequente) são unidos por um terceiro termo, O número 316 é múltiplo de 4. 
Podemos considerar o raciocínio dedutivo como a argumentação quando partimos de premissas consideradas verdades universais, com casos gerais, e concluímos sobre a veracidade de casos particulares.

Para Maritain, o raciocínio indutivo acontece quando o indivíduo conclui uma verdade universal a partir de dados singulares que são partes desse universo. $\mathrm{O}$ autor argumenta que:

Nosso espírito pode também mover-se partindo dos dados sentidos e dos fatos experiência, que constituem a primeira fonte de todo o nosso conhecimento e que pertence a ordem do individual ou do singular. (MARITAIN, 2001, p. 186)

Por exemplo:

- 1 + 3 é par; $5+7$ é par; $11+13$ é par; $27+75$ é par (antecedente):

logo, a soma de de dois números ímpares é sempre um número par (consequente).

Nesse caso, o antecedente e o consequente estão unidos não por conta de um terceiro termo, mas por conta das partes subjetivas entre as afirmações.

Podemos reconhecer o raciocínio indutivo como a argumentação quando partimos de premissas consideradas verdades particulares, e concluímos sobre a veracidade universal de situações das quais esses dados particulares fazem parte.

Uma característica do raciocínio indutivo é a possibilidade de gerar afirmações que podem ser refutadas posteriormente. Por exemplo, vejamos o caso da afirmação:

- $F(x): x^{2}-x+41$ é primo para todo $x \in \mathbb{N}$.

Podemos observar que as sentenças $F(1)=41, F(2)=43, F(3)=47, F(4)=53$ e $F(5)$ = 61 são verdadeiras. Entretanto a afirmação é falsa para $\mathrm{F}(41)=1681$, pois 1681 é divisível por 41 e, portanto, não é um número primo. Esse fato é suficiente para refutar a afirmação inicial de que $F(x): x^{2}-x+41$ é primo para todo $x \in \mathbb{N}$.

Por motivos como esse a comunidade matemática, ao pensar em produções de provas por indução, apesar de se apoiar em exemplos, busca a generalidade para garantir a veracidade da conclusão. Por exemplo, consideremos a afirmação: 
Por motivos como esse, os matemáticos desenvolveram uma técnica de prova por indução para garantir que uma afirmação é verdadeira para todo número natural, depois de verificar que ela vale em alguns exemplos. Vejamos um exemplo.

$$
\begin{aligned}
& \text { É possível verificar que } \\
& \begin{array}{l}
1=1^{2} \\
1+3=4=2^{2} \\
1+3+5=9=3^{2} \\
1+3+5+7=16=4^{2}
\end{array}
\end{aligned}
$$

etc.

Observando-se esse padrão, é possível conjecturar que a soma dos primeiros números ímpares consecutivos é sempre um quadrado perfeito, ou, mais precisamente,

$$
1+3+5+\ldots+(2 x-1)=x^{2}, \text { para todo } x \in \mathbb{N}
$$

Note que a frase (*) é, na verdade, uma coleção infinita de afirmações, uma para cada valor de $x$. Embora tenhamos verificado para alguns casos, não podemos assumir que ela seja verdadeira para todo $x$.

Se continuássemos fazendo contas e chegássemos a uma sentença falsa, teríamos provado que a afirmação é falsa. Entretanto, essa afirmação é verdadeira para todo x natural. A técnica para demonstrar esse fato está baseada no princípio de indução, que é consiste em dois passos: o passo básico é provar que a afirmação é válida para $x=1$. O segundo passo, chamado passo de indução, consiste em provar que, para todo $k$ fixado, a validade da sentença para $k$ implica que ela é válida para $k+1$. A ideia é análoga a mostrar que uma fileira de dominós pode ser derrubada se (1) o primeiro dominó for derrubado - passo básico - e (2), a derrubada de qualquer dominó acarreta na derrubada do dominó seguinte.

No caso do exemplo, temos:

O passo básico é verdadeiro já que $1=1^{2}$;

Para o passo de indução, supomos que $1+3+5+\ldots+(2 x-1)=x^{2}$ para algum $x$, e precisamos provar que vale para $x+1$.

Temos: 


$$
1+3+5+\ldots+(2 x-1)+[2(x+1)-1]=[1+3+5+\ldots+(2 x-1)]+(2 x+1)=x^{2}+
$$
$2 x+1=(x+1)^{2}$

Dessa forma, pode-se concluir, por indução, a fórmula (*)

É importante observar que para elaborar uma prova, muitas vezes precisa-se descobrir novos resultados. Neste caso, foi preciso perceber que se $x$ é um número natural, o próximo ímpar maior do que $2 x-1$ é $2 x+1$.

É claro que em outras áreas de desenvolvimento também são observadas diversas formas de raciocínio, e então assumimos que a Matemática, ou a aprendizagem em Matemática, não é a única maneira que uma pessoa possui para desenvolver e melhorar a capacidade de raciocinar logicamente. Seria um erro cravar a Matemática como a única fonte de desenvolvimento de raciocínio lógico indutivo ou dedutivo. Nesse sentido, Machado afirma que:

$\mathrm{Na}$ verdade, o exercício do raciocínio favorece a organização do pensamento, e para isso qualquer tema pode ser utilizado como veículo. $\mathrm{O}$ acompanhamento cuidadoso mesmo de um texto de natureza teleológica, como é a suma Teológica, de Santo Tomás de Aquino, pode desempenhar importante papel no desenvolvimento da capacidade de argumentar. (MACHADO, 1993, p.77)

Sobre o tema, Machado diz que não está em discussão o fato claro de que o ensino da Matemática contribui para o desenvolvimento do raciocínio. O que o autor questiona é o superdimensionamento do papel da Matemática, ou ainda de uma exclusividade da disciplina em relação ao desenvolvimento do raciocínio dos alunos que estão aprendendo determinado conteúdo.

Trouxemos essa questão pois, para que a Matemática "cumpra" o seu esperado papel em relação ao desenvolvimento do raciocínio, é necessário que as propostas em sala de aula sejam convergentes com o slogan, que segundo Machado (1993) existe em nossas escolas e consequentemente em nossa sociedade, de que "é importante estudar Matemática, pois é o que desenvolve o raciocínio". É neste ponto que traçamos os principais objetivos do trabalho, pensando em propostas de atividades que propiciem ao aluno o desenvolvimento das habilidades que envolvem a argumentação e prova matemática, e como consequência, ajude a desenvolver os raciocínios lógicos dedutivo e indutivo do indivíduo. Para nós é claro o elo entre 
o desenvolvimento do raciocínio e a habilidade em argumentação e prova matemática e, sendo assim, como professores, devemos atrelar os conteúdos trabalhados na Matemática escolar a aulas que facilitem o processo desse desenvolvimento com ciência do que e do porquê estamos fazendo, ou então estaremos apenas, como diz Machado, agindo por um ato de fé, e fazendo o papel de um professor que:

(...) segue desenvolvendo os conteúdos programáticos previstos, ano após ano, mesmo utilizando formas de abordagens interessantes, com relação à finalidade anunciada ele nunca saberá se conseguiu realizar a tarefa. (...) A eliminação de tal distância entre o discurso e a ação só é possível através de uma maior consciência dos mecanismos que relacionam o ensino dos diversos conteúdos com o desenvolvimento da capacidade de pensar logicamente. (MACHADO, 1993, p. 76)

Sendo assim, é difícil haver desenvolvimento do raciocínio lógico e da capacidade de argumentação, caso a abordagem e as atividades sejam realizadas sem que o professor pense no assunto.

Apoiando-nos no interesse da relação entre raciocínio lógico e argumentação e prova matemática, vamos apresentar um estudo sobre a problemática no contexto da Educação Básica.

Usamos de nossa experiência em sala de aula para verificar que as provas matemáticas, que tanto utilizam o raciocínio lógico dedutivo, estão distantes das abordagens realizadas em turmas de Ensino Básico no Brasil. Embora os PCN enfatizem a importância do desenvolvimento da habilidade de argumentar, é difícil percebermos em alunos de turmas de Ensino Fundamental e Médio o domínio de tal habilidade em um nível desejado. Segundo os Parâmetros Curriculares Nacionais:

É desejável que no terceiro ciclo se trabalhe para desenvolver a argumentação, de modo que os alunos não se satisfaçam apenas com a produção de respostas a afirmações, mas assumam a atitude de sempre tentar justificá-las. Tendo por base esse trabalho, pode-se avançar no quarto ciclo para que o aluno reconheça a importância das demonstrações em Matemática, compreendendo provas de alguns teoremas. (BRASIL,1998, p. 71) 
A relevância que os PCN têm para o ensino de Matemática, nos direciona para a importância de pensarmos em atividades que visam o desenvolvimento de provas na Educação Básica.

Muitos professores acreditam que argumentação, prova e demonstração não sejam práticas da sala de aula, com a justificativa de que é algo raramente compreendido na Educação Básica, e apenas utilizado por grupos de matemáticos acadêmicos por se tratar de algo muito específico da área. Uma das ideias deste trabalho é exatamente fazer uma aproximação entre os conceitos de prova e demonstração com os conteúdos desenvolvidos na Educação Básica, para que tenhamos suporte no desenvolvimento da habilidade dos nossos alunos de argumentar e provar utilizando o raciocínio lógico.

Como pesquisadores, é necessário estabelecermos o que cada um dos termos, explicação, prova e demonstração, significa na ótica de uma problemática de ensinoaprendizagem. Para isso, realizamos pesquisas no campo da Educação Matemática que nos forneceram suporte para entendermos seus significados na Educação Básica.

Nesse sentido, Balacheff diz que:

Nós chamamos "explicação" um discurso visando a tornar inteligível o caráter da verdade, adquirido pelo locutor, de uma proposição ou de um resultado. As razões (raciocínios) avançadas podem ser discutidas, refutadas ou aceitas.

Nós chamamos de "prova" uma explicação aceita por uma dada comunidade num dado momento. Esta decisão pode ser o objetivo de um debate sobre o qual a significação é a exigência de determinar um sistema de validação comum aos interlocutores.

No meio da comunidade matemática podem ser aceitas por provas explicações que adotam uma forma particular. Elas são uma sequência de enunciados organizados seguindo regras determinadas: um enunciado é tido como verdadeiro, ou bem, é deduzido daqueles que os precedem com a ajuda de uma regra de dedução tomada num conjunto de regras bem definidas. Nós chamamos estas provas de demonstração. (BALACHEFF, 1987, p. 147, tradução nossa)

Nos apoiando em Balacheff, temos uma possível distinção entre prova e demonstração na Educação Básica. É importante notar a referência para tais termos em relação à comunidade 
matemática, pois o que temos, em geral, é a prova como um argumento axiomático rigoroso. Logo, na comunidade escolar, podemos levar em considerações significados diferentes em relação à argumentação, prova e demonstração.

É evidente que não buscamos que nossos alunos tenham a capacidade de reprodução dessas provas que o professor aprende na universidade, mas sim, como defende Pietropaolo (2005) de "fazer matemática" em sala de aula, desenvolvendo assim experimentações, conjecturas e argumentações. Nesse aspecto, é necessário que as ideias e diferenças entre provar e demonstrar estejam bem claras para o professor.

Em uma visão da comunidade matemática, podemos perceber que as palavras demonstração e prova são utilizadas como sinônimos, e as palavras justificativas, argumento, explicação, servem para representar uma conclusão menos sistemática e, normalmente, menos formal. É fácil notarmos divergências nos sentidos dados a esses termos entre os autores pesquisados. Mas, em geral, podemos perceber que a ideia de prova em uma comunidade matemática difere dos significados de prova utilizados por Balacheff (1987) no contexto da Educação Matemática.

Como argumenta Pietropaolo (2005), a Matemática é uma ciência que se diferencia das outras pela aceitação de seus resultados. Em Biologia, por exemplo, os resultados podem ser testados e utilizados como verdade, mas podem surgir novas conclusões a partir de testes que mudariam a prática estabelecida anteriormente. Já o matemático, ao contrário, poderá verificar um resultado de várias maneiras e em vários casos particulares, mas somente o aceitará após demonstrá-lo rigorosamente. $\mathrm{O}$ autor argumenta que os resultados de demonstrações são de caráter universal e atemporal, e apresentam verdade absoluta, enquanto outras ciências garantem resultados aproximados. Pietropaolo faz uma citação que mostra o significado das demonstrações para a comunidade matemática:

Para muitos matemáticos a validade de um enunciado deve ser comprovada por meio de uma cadeia de raciocínios dedutivos a partir de um número reduzido de proposições aceitas. Entretanto, a demonstração não é realizada apenas levando em conta a perspectiva da lógica matemática. Bicudo (2002), por exemplo, considera que a "demonstração, como definida nos textos da Lógica Matemática, deveria modelar as demonstrações matemática. Não é, no entanto, o que se vê nos livros e jornais matemáticos. A demonstração matemática é o que satisfaz a comunidade de especialistas." (BICUDO, 2002, p. 79 Apud PIETROPAOLO, 2005, p. 60) 
É nesse aspecto de prova que temos grande diferença quando nos referimos ao ensino de Matemática. Para um especialista, uma prova é uma conclusão realizada com o uso de raciocínio dedutivo sistematizado. Porém, ao nos referirmos a uma prova no contexto escolar e na ótica da problemática de ensino-aprendizagem, consideramos prova segundo a perspectiva de Balacheff (1987), ou seja, prova é uma explicação aceita por uma determinada comunidade em determinada época. Uma prova é aceita no momento em que a comunidade é convencida da sua validade. A diferença é clara quando pensamos simplesmente que uma comunidade escolar não é igual a uma comunidade formada por matemáticos, já que as suas necessidades são certamente distintas. Ressaltamos que tal definição de prova nos ajudará a valorizar os estudos e desenvolvimento realizados pelos alunos da Educação Básica, considerando aspectos essenciais da comunidade matemática, mas não se submetendo às exigências de validade ou não validade de uma prova em tal comunidade.

Após as definições necessárias, os artigos, livros e diversas publicações lidas, tais como os trabalhos de Balacheff (1987 e 1988), Rezende e Nasser (1994) e Machado (1993), fizeram com que outras perguntas surgissem. Entre elas, destacamos a questão:

- Por que trabalhar argumentação e prova com alunos da Educação Básica?

\subsection{A prova no currículo da educação básica}

É relativamente fácil encontrar respostas para a pergunta “por que argumentar, provar e demonstrar? ”, em pesquisas sobre Matemática pura, como por exemplo, em um dos trabalhos de Fossa:

\footnotetext{
"Mas afinal, por que esta preocupação toda com demonstração? Bem, o matemático tem pelo menos dois motivos básicos para demonstrar todos os seus teoremas. O primeiro motivo é que algumas proposições que parecem intuitivamente óbvias são de fato falsas“ (FOSSA, 2009, p. 45).
}

Fossa ressalta que o segundo motivo para a insistência em demonstrar todos os teoremas matemáticos é geralmente esquecido. $\mathrm{O}$ autor argumenta que a Matemática é um tipo de conhecimento. 
A sociedade não tem dificuldade em receber a Matemática como um conhecimento importante para o desenvolvimento da ciência e da tecnologia. Mas é igualmente importante perceber a influência da Matemática para o desenvolvimento da sociedade, que usufrui do conhecimento por ela proporcionado, mudando completamente o modo de vida das pessoas ao longo dos séculos. A Matemática é uma área cultural importante, tem linguagem própria e formas de validação consistentes que lhe são peculiares. Conhecer tanto a linguagem como a articulação das ideias pode e deve ser aprendido desde cedo na escola.

Considerando as afirmações de Fossa, é razoável que, antes de respondermos à pergunta “Como propiciar o desenvolvimento de argumentação matemática pelos alunos?”, temos, como pesquisadores e professores de Matemática, que responder à pergunta "Por que aprender e ensinar de modo a auxiliar o desenvolvimento da argumentação matemática?”.

Estendemos aqui os motivos escritos por Fossa (2009) a todos os estudantes de Matemática. Não necessariamente precisamos tratar de questões matemáticas. Para o primeiro motivo podemos nos apoiar em situações fora do contexto escolar, em que pensamos que algo é obviamente verdadeiro, e por algum argumento convincente concluímos ser falso. Para o segundo motivo, e não menos importante, podemos apelar para a capacidade e desenvolvimento do raciocínio. Aliás, segundo Machado (1993), isso é algo sempre citado como um dos motivos principais para o ensino/aprendizagem de Matemática, e temas que possibilitam desenvolver a argumentação não são diferentes.

Seguindo ainda o pensamento de Fossa, demonstrar é dar razões - argumentos que devem garantir uma verdade. Assim como na Matemática, qualquer que seja a área, para conhecer uma coisa não é meramente suficiente se acreditar nela. É necessário ter razões convincentes.

De um ponto de vista da Educação Matemática, podemos recorrer aos PCN do Ensino Fundamental para justificar os motivos pelos quais se considera a argumentação matemática de grande importância. Segundo o documento:

A compreensão dos fenômenos que ocorrem no ambiente - poluição, desmatamento, limites para uso dos recursos naturais, desperdício - terá ferramentas essenciais em conceitos (médias, áreas, volumes, proporcionalidade, etc.) e procedimentos matemáticos (formulação de hipóteses, realização de cálculos, coleta, organização e interpretação de dados estatísticos, prática da argumentação, etc.) (BRASIL, 1998, p. 27). 
Tal parágrafo dos PCN vai ao encontro do que Machado (1993) e Santaló (1996) defendem sobre a utilidade da Matemática na vida de cada cidadão, quando dizem que o aprendizado e a compreensão da Matemática pelo aluno fazem com que o sujeito não seja apenas um usuário da tecnologia atual, mas sim um entendedor de suas funções, e aproveite-a da melhor maneira possível.

Podemos, de fato, pensar na argumentação e prova matemática como parte importante das habilidades que se espera que o aluno desenvolva para que possa compreender o mundo de modo cada vez mais profundo.

Nas últimas três décadas, ocorreu um crescimento grande no número de pesquisas, ao redor do mundo, sobre a importância de demonstrações na Educação Básica. $O$ international Hanbook of Mathematics Education, por exemplo, possui um capítulo cujo nome é "Proof and proving”, de Hanna e Jahnke (1996), pesquisadores que produziram diversos artigos sobre o tema e são referência para muitos outros. Alguns trabalhos nacionais que se basearam em Hanna e Jahnke foram fundamentais para a nossa visão sobre a necessidade de se trabalhar argumentação e prova na Educação Básica.

Ressaltamos o trabalho desenvolvido por Nasser e Tinoco (2003), no livro Argumentação e prova no ensino de Matemática. Nesse trabalho, as autoras publicaram os resultados de pesquisas desenvolvidas por um grupo de professores do Projeto Fundão do Instituto de Matemática da Universidade Federal do Rio de Janeiro, em que são aplicadas diversas atividades seguindo as premissas das referências bibliográficas sobre a importância das atividades envolvendo argumentação e prova na escola de Educação Básica.

Outra pesquisa bastante grande e significativo é o projeto AProvaME (Argumentação e Prova na Matemática Escolar) da Pontifícia Universidade Católica de São Paulo, em que alunos do curso de Mestrado em Educação Matemática trabalharam com diversas questões sobre argumentação e prova na Educação Básica, desde a formação de professores, até a aplicação de atividades com alunos e análise de resultados, partindo sempre de investigações sobre argumentação e prova no ensino da Matemática, considerando fortemente o grande número de publicações de Hanna e Jahnke na área, os trabalhos de De Villiers (1990 e 2001) sobre "funções da prova", Nicolas Balacheff (1987 e 1988) e suas diversas contribuições, principalmente para os "tipos de prova” (definiremos com mais rigor no Capítulo 4). 
Todos esses autores defendem que o ensino de matemática na Educação Básica contenha abordagens envolvendo provas. $\mathrm{Na}$ realidade, durante todo o nosso levantamento bibliográfico, todos os artigos, livros e teses que lemos sobre o assunto reiteram a importância para a formação do aluno, da existência de provas matemáticas e, apesar de direcionamentos distintos, não encontramos nenhuma objeção ao trabalho com ensino de provas desde os anos iniciais da Educação Básica.

Considerando primordial a abordagem de atividades que incentivem a produção de argumentação e prova, abre-se um leque de pesquisas voltadas para a forma com que as práticas de ensino são realizadas em sala de aula, objetivando o desenvolvimento de provas matemáticas pelos educandos. Segundo Pietropaolo (2005), seja em livros, periódicos ou em sala de aula, as demonstrações são normalmente realizadas via um processo lógico dedutivo, com uso de um sistema de axiomas e, sendo assim, tal abordagem pode levar o aluno a pensar a Matemática somente pelo modo em que é apresentada. $\mathrm{O}$ autor diz que se todas as demonstrações forem apresentadas dessa forma, na realidade o professor estará sempre expondo o produto, e não o processo, e que:

Produtos e processos matemáticos distinguem-se indubitavelmente, sendo esta diferenciação uma realidade defendida por diversos educadores e matemáticos de renome, como Polya e Lakatos. A Matemática é, certamente, uma ciência dedutiva, mas suas demonstrações surgem da combinação de observações, do emprego de analogias e experimentações variadas, envolvendo um óbvio processo especulativo denominado por Polya de inferência plausível.

Assim, é compreensível que a análise tão somente do produto matemático final iluda o observador, ocultando a natureza dos processos empregados para obtenção deste produto. Partindo de um conjunto de axiomas e definições complexas e com tantas condições que fica difícil imaginar que, em algum momento passado, foram concebidas de alguma forma - e inferências reputadas válidas, atingem-se verdades dogmáticas, inquestionáveis. (PIETROPAOLO, 2005, p. 77).

Pietropaolo conclui que quando uma prova é realizada somente e diretamente pelo processo lógico dedutivo, o professor está ocultando o processo demonstrativo original, a ideia pela qual se formulou o teorema e todos os testes que antecederam o produto final. 
Nesse sentido, os trabalhos De Villiers (1990 e 2001), Nasser e Tinoco (2003), defendem que o processo de demonstração na Educação Básica deve passar por todas as etapas em que normalmente são submetidas por um matemático para "encontrar" algum teorema. Para De Villiers (2001), a demonstração dedutiva para verificação não é a única função da demonstração na Matemática, e tampouco será para a Educação Matemática, apesar de que livros e artigos direcionados para matemáticos profissionais apresentem apenas a demonstração dedutiva como forma de descoberta de um teorema, mesmo que a sua ideia inicial e convencimento partam de testes ou percepções de padrões. Nesse caso a demonstração axiomática é, na realidade, um processo formal de validação e não de descoberta. Embora os testes não sejam apresentados em provas, são importantíssimos para a formulação de conjecturas, descoberta de teoremas que possam ser demonstrados posteriormente por um processo axiomático, ou ainda para encontrar contraexemplos para refutar uma afirmação. Sobre a relevância dos testes, De Villiers (2001) diz que "a falta de êxito na rejeição empírica de conjecturas desempenha, na procura da convicção, um papel tão importante como o processo da justificação dedutiva” (p. 32). Vale salientar que os PCN deixam claro ao professor de Matemática que:

Quando se reflete, hoje, sobre a natureza da validação do conhecimento matemático, reconhece-se que, na comunidade científica, a demonstração formal tem sido aceita como a única forma de validação dos seus resultados. Nesse sentido, a Matemática não é uma ciência empírica. Nenhuma verificação experimental ou medição feita em objetos físicos poderá, por exemplo, validar matematicamente o teorema de Pitágoras ou o teorema relativo à soma dos ângulos de um triângulo. Deve-se enfatizar, contudo, o papel heurístico que têm desempenhado os contextos materiais como fontes de conjecturas matemáticas. Essas características permitem conceber o saber matemático como algo flexível e maleável às inter-relações entre os seus vários conceitos e entre os seus vários modos de representação, e, também, permeável aos problemas nos vários outros campos científicos. Um saber matemático desse tipo pode ser o motor de inovações e de superação dos obstáculos, desde os mais simples até aqueles que significam verdadeiras barreiras epistemológicas no seu desenvolvimento. (BRASIL, 1998, p. 26)

Logo, a prova realizada em sala de aula sem testes, sem analogias, sem observações de padrões, na realidade se distancia da maioria das provas matemáticas construídas pela própria 
comunidade matemática. Estaríamos assim desconsiderando justamente os motivos pelos quais se deve desenvolver o hábito de argumentar e provar na Educação Básica.

Os Parâmetros Curriculares Nacionais, dizem também que:

O acervo de conhecimento matemático tem sido preservado e exposto pela via da dedução lógica, no âmbito de um sistema de axiomas. A comunicação do saber matemático, seja nos periódicos especializados e nos livros, seja nos vários ambientes escolares, tem, tradicionalmente, seguido esse caminho. $\mathrm{Na}$ criação desse conhecimento, contudo, interferem processos heurísticos e intervêm a criatividade e o senso estético, do mesmo modo que em outras áreas do conhecimento. A partir da observação de casos particulares, as regularidades são desvendadas, as conjecturas e teorias matemáticas são formuladas. Esse caráter indutivo é, em geral, pouco destacado quando se trata da comunicação ou do ensino do conhecimento matemático. (BRASIL, 1998, p. 25)

A reflexão contida nos PCN vai ao encontro da análise feita por Pietropaolo (2005) e anteriormente citada.

Enfatizando a questão: "Por que desenvolver atividades de argumentação em sala de aula?", Nasser e Tinoco (2003) baseiam seu trabalho no artigo de Galbraith (1981), em que o autor apresenta uma lista de componentes necessários para a compreensão, construção e a análise de provas:

a) Entender e ser capaz de chegar uma variedade de casos particulares;

b) Detectar e utilizar um princípio externo relevante para argumentação;

c) Utilizar uma cadeia de inferências a fim de se convencer do resultado a ser alcançado;

d) Reconhecer o domínio de validade de uma generalização;

e) Interpretar corretamente condições e afirmativas;

f) Apreciar e perceber a distinção entre implicação e equivalência;

g) Reconhecer a arbitrariedade e propriedades de uma definição;

h) Ser capaz de analisar uma prova como meio de expor os detalhes de um argumento. (NASSER E TINOCO, 2003, p. 7) 
Todo o trabalho desenvolvido por Nasser e Tinoco (2003) teve como objetivo que o aluno deva dominar o processo de prova e demonstração ao ponto de desenvolver as habilidades mencionadas acima. As autoras reforçam a ideia de que é de fundamental importância que o professor esteja ciente de que precisa explorar, em suas aulas de Matemática, atividades que possibilitem o desenvolvimento de tais habilidades que, claro, são aperfeiçoadas aos poucos.

Podemos perceber, a partir das leituras feitas ao longo do desenvolvimento deste trabalho, que outras pesquisas, nacionais e internacionais, convergem para pontos bem específicos e deixam claro que atividades envolvendo argumentação e prova na Educação Básica são indispensáveis. Logo, concluímos ser fundamental que o currículo contemple diretrizes voltadas para o desenvolvimento de habilidades que envolvam argumentação e prova matemática por parte de nossos alunos. Por outro lado, a abordagem não deve ser a de exposição de uma demonstração em lousa, ou apresentação do produto final de uma prova, por exemplo. O processo da prova deve ser valorizado visando o desenvolvimento das habilidades de argumentação pelo aluno, e não somente a produção ou reprodução de demonstrações matemáticas como estão apresentadas em livros didáticos.

Para que pudéssemos compreender a situação atual do ensino de Matemática no Brasil, especificamente o desenvolvimento de provas por nossos estudantes, analisamos os resultados do PISA (Programme for International Student) nos últimos anos.

\subsection{Descrição de resultados do PISA}

O objetivo do Pisa, que é desenvolvido pela Organização para Cooperação e Desenvolvimento Econômicos - OCDE, é produzir indicadores que contribuam para a discussão sobre a qualidade da Educação nos países participantes, e apresenta níveis mínimos de aprendizagem desejados para cada habilidade. A avaliação procura verificar até que ponto as escolas de cada país participante estão preparando seus jovens para exercer o papel de cidadãos na sociedade.

Analisamos os resultados do PISA de 2000 até 2015. No ano 2000, o Brasil avaliou 4.893 alunos no Pisa; em 2003, 4.452 alunos. Em 2006, a amostra brasileira foi ampliada para 9.295 alunos. Em 2009, foram 950 escolas e 20.127 estudantes. No Pisa 2012 a amostra brasileira teve cerca de 25 mil estudantes. Na última avaliação, em 2015, por volta de 21 mil estudantes participaram dos testes. 
Os resultados são apresentados em seis níveis, divididos no seguinte esquema de pontuação:

\begin{tabular}{|c|c|}
\hline Nível & Pontuação \\
\hline 6 & Acima de 669 \\
\hline 5 & 607 a 669 \\
\hline 4 & 545 a 607 \\
\hline 3 & 482 a 545 \\
\hline 2 & 420 a 482 \\
\hline 1 & 358 a 420 \\
\hline
\end{tabular}

TABELA 1 - Pontuação dos níveis de habilidades do PISA

Cada ano de aplicação do PISA possui uma ênfase em determinadas áreas do conhecimento. O ensino de Matemática foi amplamente avaliado nos anos de 2003 e 2012, anos em que podemos fazer uma análise mais abrangente em relação a situação do ensino de prova matemática nas escolas brasileiras.

Nos níveis citados, quanto mais próximo do 6, maior é a habilidade desenvolvida em relação a argumentação, generalização, como mostra a tabela a seguir:

\section{Níveis de Proficiência em Matemática}

\begin{tabular}{|c|c|c|}
\hline Nivel & $\begin{array}{l}\text { Limite } \\
\text { Inferior }\end{array}$ & O que os estudantes em geral podem fazer em cada nível \\
\hline 6 & 669,3 & $\begin{array}{l}\text { No Nivel } 6 \text {, os estudantes são capazes de conceituar, generalizar e utilizar informações baseadas em } \\
\text { uas investigações e na modelagem de problemas complexos. Podem relacionar diferentes fontes de } \\
\text { informação e representação e traduzi-las entre si de maneira flexível. São capazes de demonstrar } \\
\text { pensamento e raciocínio matemático avançado. Além disso, podem aplicar essa compreensão e } \\
\text { conhecimento juntamente com a destreza para as operaçōes matemáticas formais e simbólicas para } \\
\text { desenvolver novos enfoques e estratégias para enfrentar situações novas. Podem formular e comunicar } \\
\text { com precisão suas açōes e reflexōes RESPECTO de descobertas, interpretaçōes e argumentaçōes, e } \\
\text { adequá-las a novas situaçōes. }\end{array}$ \\
\hline 5 & 607,0 & $\begin{array}{l}\text { No Nivel 5, os estudantes podem desenvolver e trabalhar com modelos de situações complexas; } \\
\text { identificar limites e especificar suposiçōes. Podem selecionar, comparar e avaliar estratégias apropriadas } \\
\text { de solução de problemas para abordar problemas complexos relacionados com esses modelos. Podem } \\
\text { trabalhar de maneira estratégica ao utilizar amplamente capacidades de pensamento e raciocínio bem } \\
\text { desenvolvidas; representaçōes por associação; caracterizaçôes simbólicas e formais; e a compreensão } \\
\text { dessas situaçōes. Podem formular e comunicar suas interpretaçōes e raciocínios. }\end{array}$ \\
\hline 4 & 544,7 & $\begin{array}{l}\text { No Nivel 4, os estudantes são capazes de trabalhar efetivamente com modelos explícitos para situaçōes } \\
\text { concretas complexas que podem implicar em limitaçōes ou exigir a realizaçāo de suposiçōes. Podem } \\
\text { selecionar e integrar diferentes representaçōes, incluindo símbolos ou associá-los diretamente a } \\
\text { situaçōes do mundo real. Podem usar habilidades bem desenvolvidas e raciocinar com certa } \\
\text { compreensão nesses contextos. Podem construir e comunicar explicaçōes e argumentos baseados em } \\
\text { suas interpretaçōes e açōes. }\end{array}$ \\
\hline 3 & 482,4 & $\begin{array}{l}\text { No Nível 3, os estudantes sāo capazes de de efetuar procedimentos descritos claramente, incluindo } \\
\text { aqueles que requerem decisōes seqūenciais. Podem selecionar e aplicar estratégias simples de solução } \\
\text { de problemas. Os estudantes neste nível podem interpretar e utilizar representaçōes baseadas em } \\
\text { diferentes fontes de informaçōes, assim como raciocinar diretamente a partir delas. Podem gerar } \\
\text { comunicaçōes breves reportando suas interpretaçōes, resultados e raciocínios. }\end{array}$ \\
\hline
\end{tabular}




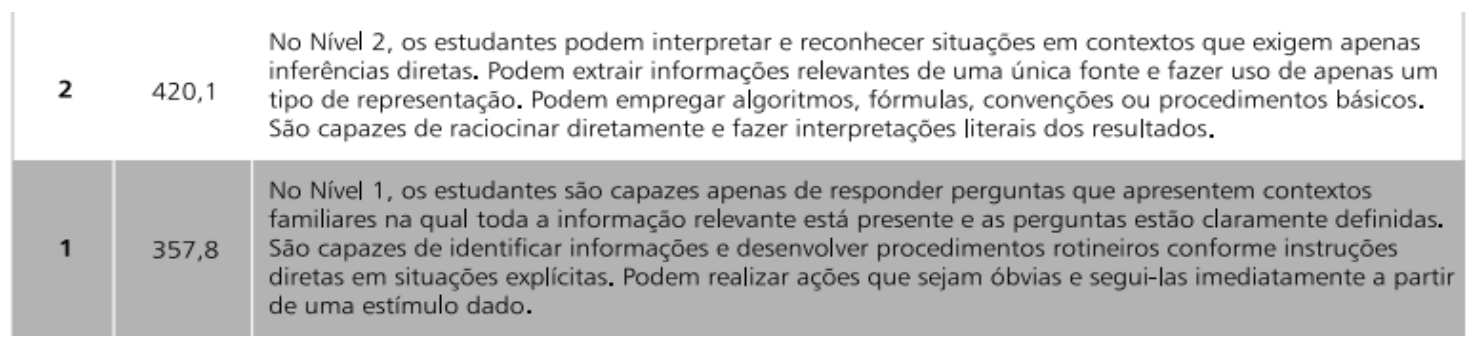

FIGURA 1 - Descrição dos níveis de habilidades do PISA. Disponível em: http://portal.mec.gov.br. Acesso realizado em 07/01/2017.

Na avaliação geral do Pisa 2003, o percentual de brasileiros em cada um dos seis níveis foi o seguinte:

\begin{tabular}{|c|c|}
\hline Níveis & Alunos \\
\hline Abaixo do nível 1 & $53,3 \%$ \\
\hline Nível 1 & $21,9 \%$ \\
\hline Nível 2 & $14,1 \%$ \\
\hline Nível 3 & $6,8 \%$ \\
\hline Nível 4 & $2,7 \%$ \\
\hline Nível 5 & $0,9 \%$ \\
\hline Nível 6 & $0,3 \%$ \\
\hline
\end{tabular}

TABELA 2 - Resultado do Pisa para estudantes brasileiros em 2003

Embora os resultados obtidos em 2003 tenham sido melhores do que os de 2000, notamos que em 2003 mais de 53\% dos estudantes foram avaliados como abaixo do nível 1, e ainda, quase $80 \%$ são capazes, de no máximo, resolver problemas que exijam inferências diretas. Apenas $0,3 \%$ dos estudantes foram avaliados no nível 6 , em que se admite que o aluno pode realizar generalizações baseados em suas observações, o que seria desejável em relação à argumentação e prova matemática.

No PISA de 2006 o foco foi Ciências, então a análise sobre Matemática é menos detalhada. Ocorreu pequena melhora em comparação com a prova anterior, entretanto, nada que mudasse o panorama apresentado na última avaliação. Como mostramos na tabela a seguir, o país apresentou, novamente, um dos piores desempenhos de todas as nações participantes em Matemática, ficando com a $54^{\mathrm{a}}$ posição de 57 países participantes. 


\begin{tabular}{|l|c|c|c|c|c|c|}
\multicolumn{1}{|c|}{ Paises } & Média & $\begin{array}{c}\text { Erro-padrão } \\
\text { da média }\end{array}$ & $\begin{array}{c}\text { Desvio } \\
\text { padrāo }\end{array}$ & $\begin{array}{c}\text { Erro-padrão } \\
\text { do desvio padrão }\end{array}$ & $\begin{array}{c}\text { Limite } \\
\text { inferior }\end{array}$ \\
\hline China /Taipei* & 549 & 4,1 & 103,1 & 2,2 & 541,3 \\
superior
\end{tabular}

FIGURA 2 - Ranking de matemática dos países participantes do PISA 2006. Disponível em: http://portal.mec.gov.br. Acesso realizado em 07/01/2017.

Em 2009, novamente o Brasil apresentou leve melhora em relação ao nível geral, sendo avaliado com o total de 386 pontos, entretanto com média abaixo do nível 2.

A melhor comparação entre as avaliações do PISA para Matemática acontece justamente nos ciclos de 2003 e 2012 por avaliar com maior abrangência as habilidades correspondentes ao ensino de Matemática.

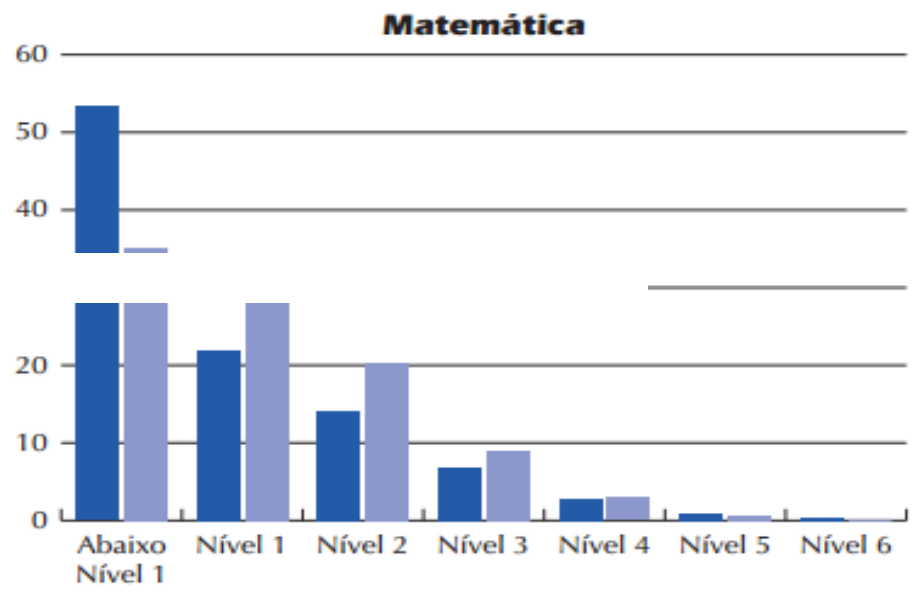

FIGURA 3 - Gráfico de comparação de resultados brasileiros, em \%, entre o PISA 2003 e 2012. Disponível em: http://portal.mec.gov.br. Acesso realizado em 07/01/2017.

Pudemos notar relevante melhora nos resultados em Matemática no PISA 2012, porém, os níveis que consideram que o aluno desenvolveu habilidades em relação a argumentação 
matemática e uso do raciocínio lógico dedutivo são os níveis 3, 4, 5 e 6. A maioria dos alunos avaliados continuam no intervalo entre "abaixo do nível 1" e "nível 2", e com concentração maior na faixa que representa menor compreensão dos temas. Em 2012, o Brasil atingiu a média de 391 pontos em Matemática, ficando apenas com a 58 colocação entre os 65 países participantes.

Por fim, em 2015 ocorreu a última avaliação do PISA. Assim como no ano de 2006, o foco foi em Ciências. Em Matemática, os alunos brasileiros obtiveram média de 377 pontos, fazendo com que o Brasil ficasse na $64^{\mathrm{a}}$ posição entre 72 países participantes.

No período de 2000 a 2015, a avaliação do PISA afirmou que na Educação Básica brasileira, os alunos, em sua maioria, não desenvolvem as habilidades necessárias de argumentação e prova matemática.

A constatação nas avaliações reforçou a nossa ideia de considerarmos como objeto de estudo atividades no campo da Matemática que possam ajudar o desenvolvimento do raciocínio dedutivo e indutivo de nossos alunos. Para isso, vamos nos apoiar em atividades que recorrem a argumentação e prova na Educação Básica, pois consideramos tais temas fontes riquíssimas para possibilidade de aquisição das habilidades em questão.

No Capítulo seguinte, apresentamos as principais Funções da Prova na Educação Básica. Nesse sentido, os conceitos de argumentar, provar e demonstrar na Matemática escolar serão apresentados com o objetivo de discutir o desenvolvimento das habilidades discutidas até aqui, e não somente para provar teoremas e lemas de conteúdos matemáticos. 


\section{Funções da prova na Educação Básica}

Consideramos como prova matemática o argumento utilizado para convencimento próprio ou de uma terceira pessoa, nos apoiando, principalmente, em Balacheff (1987, 1988), e não somente como sinônimo para demonstrações rigorosas como, em geral, são aceitas na comunidade matemática.

Direcionamos o nosso estudo para a prova matemática na Educação Básica, pois acreditamos haver funções essenciais que podem possibilitar o desenvolvimento do raciocínio dos estudantes. Nasser e Tinoco (2003) e De Villiers (1990, 1991 e 2001) expõem algumas delas com bastante clareza.

Segundo Nasser e Tinoco (2003), a função mais utilizada da prova é a de validar um resultado, ou seja, comprovar que a afirmação é verdadeira. As autoras enfatizam que nem sempre tal função é motivadora para que uma prova seja produzida pelos alunos, pois muitas vezes, o resultado da afirmação é óbvio, ou eles têm a segurança da sua veracidade pela informação de um livro ou do professor. Neste sentido, vale a pena adiantar uma das questões que abordamos com uma turma de 9o ano do Ensino Fundamental. Propomos, para os alunos, uma situação envolvendo os conhecimentos de equações de $2^{\circ}$ grau, seguida com uma afirmação contida em um suposto livro. A questão é a seguinte:

\section{A professora de Rogério pediu que ele resolvesse a equação:}

$5 x^{2}+5 x-10=0$.

O aluno encontrou as soluções $x=1$ e $x=-2$.

O livro usado pela turma apresentava as respostas $x=1$ e $x=3$.

Sabendo que a questão vale 2 pontos, considerando as respostas, qual é a nota que você daria para Rogério?

A afirmação "O livro usado pela turma apresentava as respostas $x=1$ e $x=3$ ” fez com que vários alunos dispensassem a necessidade de verificação das raízes da equação. Notamos que para esses alunos, não houve interesse em provar ou verificar se o resultado está correto, 
pois já tinham a certeza dada pela afirmação de uma fonte, para eles, inquestionável. Em uma das respostas, o aluno afirma:

Eu daria 1 ponto, pois acredito que ele tenha errado na segunda e acertado na primeira.

De Villiers (1990) diz que o principal problema no desenvolvimento de provas é justamente o aluno não perceber a necessidade de uma prova. Diz ainda que para que o aluno perceba a necessidade de provar, é essencial que a apresentação do conteúdo seja altamente baseada na negociação apropriada dessas funções de prova, ou seja, é papel do professor estimular o aluno nas questões de "por que provar" ou "nesse caso preciso provar que". O fato de que o aluno não tenha provado algo que era necessário, segundo o autor, não significa simplesmente que há um desenvolvimento mais lento do que quem conseguiu realizar argumentos contundentes em uma mesma questão. Essa diferença não pode ser diretamente atribuída ao desenvolvimento cognitivo mais lento, ou incapacidade de raciocinar logicamente. Na maioria dos casos, o que acontece é que o estudante não possui motivação para realização da prova. De Villiers apresenta alguns estudos que indicam que as crianças são capazes de raciocinar dedutivamente desde que a situação tenha real significado.

De Villiers (1990, p.18) também afirma que "tradicionalmente a função da prova tem sido quase que exclusivamente usada como uma verificação (convicção ou justificação) de uma

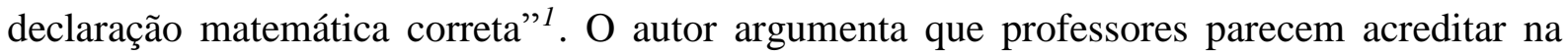
prova matemática como a única função de fornecer certeza absoluta, sendo autoridade em estabelecer uma conjectura, o que considera ingenuidade. O autor diz que a visão de que "para que haja convicção tem de haver prova" é falsa, já que prova não é necessariamente um prérequisito para convicção. Na realidade, a convicção muitas vezes é um pré-requisito para encontrar uma prova. De Villiers diz que, na maioria das vezes em que fazemos uma demonstração, é porque temos certeza de sua veracidade, mas precisamos encontrar uma prova lógica. Nesse caso, a motivação da prova não é a de verificação.

Para que o professor possa desenvolver um trabalho consciente e consistente com o objetivo de ajudar os seus alunos a argumentar e provar, é importante perceber que a prova tem várias outras funções, além de apenas verificar se um resultado matemático é verdadeiro.

\footnotetext{
${ }^{1}$ Traditionally the function of proof has been seen almost exclusively in terms of the verification (convicton or justification) of the correctness of mathematical statements. (De VILLIERS, 1990, p.18, tradução nossa)
} 
É comum em nossa prática como professor da Educação Básica, limitarmos o processo entre o "consegue argumentar" e o "não consegue argumentar", mas dificilmente nos concentramos na questão da clareza da função da prova solicitada em determinada situação.

Para que todo o processo de ensino de prova seja eficaz, devemos ter professores que tenham ciência de todas as possibilidades que cercam a habilidade de provar ou demonstrar na Educação Básica. Para melhor discutir o assunto, à frente destinamos uma parte do trabalho a alguns estudos envolvendo o conhecimento do professor (formação e visão de prova na Educação Básica) que nos ajudaram a entender o atual cenário do ensino de provas.

$\mathrm{O}$ aluno pode ter certeza sobre um resultado, mesmo não sendo necessária a verificação (ausência de prova). A não obrigatoriedade da prova para a verificação, não necessariamente limita as suas funções no campo de ensino da Matemática. $\mathrm{O}$ autor traz a análise de que:

A falta de êxito na rejeição empírica de conjecturas desempenha, na procura da convicção, um papel tão importante como o processo da justificação dedutiva. Tudo leva a crer que existe uma dimensão lógica, a par de uma psicológica, na obtenção da certeza. Logicamente, exigimos alguma forma de demonstração dedutiva, mas psicologicamente parece que precisamos ao mesmo tempo de alguma experimentação exploratória ou compreensão intuitiva. Sem dúvida, dadas as limitações próprias bem conhecidas da intuição e dos métodos quase empíricos, a argumentação precedente não significa de modo algum ignorar a importância da demonstração como um meio indispensável de verificação, especialmente no caso de resultados duvidosos ou surpreendentes, por não serem intuitivos. (DE VILLIERS, 2001, p. 33)

De Villiers (2001) apresenta, além de verificação, outras importantes funções da prova que aparecem no trabalho de um matemático profissional e que também podem aparecer na educação básica, de forma significativa, respeitando-se adequações necessárias. São elas:

- Explicação: provar que algo é verdade para um determinado público.

De Villiers defende que quando uma demonstração está para ser realizada, mas já há convencimento de sua veracidade, ou por aplicações do enunciado, ou por muitos testes, a função da prova não é a de validação, pois em nenhum momento se questiona a veracidade do enunciado, o que está em questionamento é "o porquê" do enunciado ser verdadeiro. Dessa 
forma, a função da demonstração é a de explicação. Às vezes, quando temos certeza sobre a validade/veracidade do enunciado, sentimos ainda a necessidade de uma demonstração. Caso estejamos participando do desenvolvimento de uma prova, podemos desejar ainda a demonstração porque se algo é verdadeiro e não conseguimos realizar as provas através de raciocínios dedutivos, é um sinal de que não compreendemos tudo o que há no enunciado.

- Descoberta: dedução ou invenção de novos resultados.

Embora em muitos casos os teoremas sejam provados por uma linha de raciocínios dedutivos após o convencimento por testes ou por análise intuitiva do enunciado, há muitas situações em que as demonstrações são também descobertas matemáticas. Aqui há uma grande importância no uso da prova em sala de aula. Basta notarmos que normalmente os enunciados dos exercícios pedem para verificar se algo é verdadeiro, o que não desperta a "vontade de descoberta" no estudante. Ao agirmos dessa forma, nós professores, estamos limitando as aplicações de funções da prova em sala de aula e, consequentemente, freando a possibilidade de desenvolvimento da habilidade de argumentar, provar e demonstrar por parte de nossos alunos.

- Sistematização: a organização de vários resultados dentro de um sistema dedutivo de axiomas, com mais conceitos e teoremas.

A sistematização é indispensável para que se organizem resultados conhecidos em uma estrutura de axiomas e conceitos que explicam e mostram as principais relações lógicas contidas na situação. Segundo o autor, a sistematização na prova:

- Ajuda a identificar inconsistências, argumentos circulares, e hipóteses escondidas ou não explicitamente declaradas.

- Unifica e simplifica as teorias matemáticas ao integrar e ligar entre si afirmações, teoremas e conceitos não relacionados, conduzindo assim a uma apresentação económica dos resultados.

- Fornece uma perspectiva global ou vista de conjunto de um tópico, ao mostrar a estrutura axiomática subjacente do tópico a partir da qual todas as outras propriedades podem ser derivadas.

- Constitui uma ajuda para as aplicações tanto dentro como fora da matemática, pois torna possível verificar a possibilidade de aplicação de toda uma estrutura complexa ou teoria através de uma avaliação da aplicabilidade 
dos seus axiomas e definições.

- Conduz muitas vezes a sistemas dedutivos alternativos que fornecem novas perspectivas e/ou são mais económicos, elegantes e poderosos do que os existentes. (DE VILLIERS, 2001, p. 34).

Notamos que as funções da prova muitas vezes se relacionam. Na questão da sistematização, podemos pensar em alguns casos em que também há a função de verificação, mas esse não é o objetivo geral. A ideia da sistematização é de organizar informações isoladas, que já se sabe que são verdadeiras, e unificar o pensamento, ou seja, pensar de forma global. O mesmo serve para relacionar explicação e sistematização. Por mais que se saiba sobre as suas características lógicas para cada exemplo, o intuito é o de generalizar todas as características em um sistema lógico dedutivo, ou seja, encontrar um argumento que sirva para toda a classe de objetos e não somente para casos particulares.

- Comunicação: transmissão de conhecimento matemático.

Baseado em Davis e Hersh (1986), De Villiers (2001) expõe que a demonstração é uma forma de interação humana, um meio de comunicação entre pessoas fazendo matemática: uma comunicação entre matemáticos profissionais, entre professores e alunos, e entre os próprios estudantes. Com tal comunicação, é possível que uma ideia seja desenvolvida por várias pessoas ao mesmo tempo e, dessa forma, que possíveis erros sejam corrigidos, ou então que a demonstração seja negada quando algum contraexemplo é descoberto.

- Desafio intelectual: a realização pessoal/gratificação resultantes da construção deuma demonstração.

Em um curso de Matemática, é absolutamente normal encontrarmos matemáticos pesquisadores, estudantes ou professores, em contato com uma cadeia de axiomas e teoremas, utilizando raciocínio lógico dedutivo com o objetivo de provar algum resultado. Muitas vezes o enunciado já está demonstrado em algum livro, ou artigo, mas a busca pela demonstração rigorosa e aceitável no meio acadêmico continua. De Villiers diz que esse desafio intelectual é uma das funções da prova na Matemática. Escreve ainda que para matemáticos, provar algo traz a mesma sensação do que qualquer projeto criativo realizado em outras áreas, como por exemplo, terminar uma maratona ou triatlo, ou seja, traz a satisfação de concluir, de alcançar os objetivos. 
Por fim, baseando-nos em De Villiers (2001), é importante ressaltarmos dois pontos:

- as funções da prova podem se relacionar sem que haja perda de significado. Em alguns casos, uma função pode prevalecer sobre outra.

- foram apresentadas algumas das importantes funções da prova, mas esta lista de funções não é de forma alguma completa. Poderíamos considerar uma função, por exemplo, de memorização, ou ainda de desenvolvimento algorítmico.

No próximo capítulo, iremos apresentar um estudo importantíssimo sobre os vários níveis de argumentações e provas que alunos da Educação Básica podem desenvolver, que denominamos por tipos de prova. 


\section{Tipos de prova no contexto escolar}

Nossa experiência atuando na Educação Básica e também por frequentarmos ambientes de cursos de graduação e pós-graduação nos motivou a realizar pesquisas neste campo, principalmente após notarmos a fragilidade que tínhamos no ensino e na análise de provas desenvolvidas por nossos estudantes. Ao concluirmos a graduação, ingressamos como professores de Matemática na Educação Básica após provarmos e demonstrarmos dezenas de teoremas durante o curso de Matemática, modelando a visão de demonstração, de forma demasiadamente rigorosa, seguindo os passos do processo lógico formal e axiomático.

Com as leituras dos trabalhos de Nasser e Tinoco (2003), Rezende e Nasser (1994), Sowder e Harel (1998), Pietropaolo (2005), Hanna (1990), Boa vida (2005), Matheus (2016), Almouloud et al (2008), Almouloud e Fusco (2010), pudemos concluir que é essencial que, para que o aluno tenha aumentadas as chances de desenvolvimento do raciocínio lógico dedutivo, consiga expressar argumentações válidas para certas afirmações, dar explicação convincente ou estabelecer critério para decidir se uma sentença é verdadeira ou falsa, o professor deve compreender e aceitar diversos tipos de argumentação e provas que os estudantes apresentam e, como consequência, saber quais ações ele deve realizar em sua prática docente visando o desenvolvimento das habilidades de argumentação e prova matemática do educando.

Segundo Balacheff (1987), em relação ao ensino na França, no terceiro ano do secundário $^{2}$, na época da publicação de seu trabalho, havia uma grande ruptura do contrato didático a respeito da atividade matemática dos anos anteriores. É uma passagem de uma "Matemática prática", em que os alunos se certificam dos resultados sem trabalhar com generalizações, para uma "Matemática teórica", por conta justamente de um tratamento com argumentação, provas e demonstrações com base em uma linguagem matemática. $\mathrm{O}$ autor, em seus diversos trabalhos, faz questão de evidenciar a diversidade do processo de prova e os

\footnotetext{
${ }^{2}$ Livre tradução de: troisième annèe de I'enseignement secondaire - Equivalente ao 9o ano do ensino Fundamental no sistema de ensino brasileiro.
} 
elementos da complexidade de seu funcionamento. O estudo de Nicolas Balacheff propõe diferenciar e estruturar níveis de prova, desde argumentações com base em testes com casos particulares até as demonstrações matematicamente rigorosas, entretanto dentro de uma perspectiva de ensino/aprendizagem.

\subsection{O problema da contradição}

Balacheff (1987) considera o problema da contradição como um dos pilares para a realização e análise da veracidade de provas matemáticas, tomando como ponto de partida que uma das finalidades de uma prova é mantê-la fora dos riscos de existência de contradições que possam torná-la inválida. O autor afirma que a contradição, colocada em discussão sobre validação de uma afirmação, não pode ser reduzida apenas a uma complexidade lógica:

Vamos considerar a hipótese de que uma contradição não existe a menos que um interlocutor/testemunha a construa. (Grize et al, 1983). Isso significa que uma contradição não existe em si, mas relativamente a um sistema cognitivo. Em consequência, uma contradição provada por uma testemunha pode ser negada ou inexistente para outro indivíduo. (BALACHEFF, 1987, p. 148, tradução nossa)

O autor indica que na perspectiva da relação ensino/aprendizagem, é imprescindível ressaltar que uma contradição para um professor, pode não ser uma contradição para um aluno, ou ainda, uma contradição apresentada por um estudante, mesmo que para ele esteja claro e bem justificado, pode não existir para um professor.

Balacheff (1987) exemplifica um problema em que os professores de geometria são frequentemente testados em sala de aula, principalmente no Ensino Fundamental: a soma dos ângulos internos de um triângulo na geometria euclidiana. É um caso em que uma contradição pode ser atestada pelos alunos enquanto que para o professor ela não existe. $\mathrm{O}$ autor alega que para muitos alunos, a soma dos ângulos internos de um triângulo não pode ser sempre $180^{\circ}$, porque triângulos maiores possuem ângulos maiores e, sendo assim, elevam a soma dos três ângulos internos. Entretanto, para o professor de Matemática que já está convencido pela apresentação da prova formal, essa contradição é inexistente. 
A hipótese de Balacheff é que a tomada de consciência de contradições leva à evolução das concepções dos alunos e, como consequência, é uma problemática de fundamental importância para o progresso do conhecimento.

Dentro da questão de ensino/aprendizagem, o saber matemático científico ou escolar fornece ao professor a responsabilidade quanto à decisão sobre o carácter contraditório de uma afirmação ou situação. Balacheff (1987) se apoia em Piaget para concluir que a tomada de consciência de uma contradição precisa estar dentro de um nível que o aluno seja capaz de ultrapassar. Argumenta ainda que tomar consciência de uma contradição é colocar o problema de escolha entre uma afirmação e uma negação. Sendo assim, independentemente do resultado dessa escolha, supõe-se que a afirmação está disponível e que ela é passível de ser negada. Balacheff (1987) considera então que a contradição é dependente dessa dupla construção, e sustenta a ideia de que a tomada de consciência se produzirá somente quando o sujeito for capaz dessa dupla construção. Fazendo uma relação com o exemplo citado anteriormente sobre a contradição existente para o aluno e não para o professor na soma dos ângulos internos de um triângulo na geometria plana, o autor alerta que:

Uma vez que a contradição seja identificada pelo aluno, sua ultrapassagem pode, entretanto, não acontecer a não ser após um longo trabalho. Assim, no caso da medida dos ângulos de um triângulo, a ultrapassagem da contradição já evocada vai exigir uma retomada das concepções que o aluno tem sobre a medida de um ângulo e por sua apropriação do postulado de Euclides e suas consequências. Se o cenário que relaciona as proposições "quanto maior um triângulo, maior é a soma de seus ângulos" e " a soma dos ângulos de um triângulo é $180^{\circ}$ " abre acesso à contradição, não é suficiente para sua ultrapassagem. (BALACHEFF, 1987. p. 150, tradução nossa)

Balacheff indica duas condições como necessárias à tomada de consciência de uma contradição. São elas:

(i) existência de uma expectativa;

(ii) possibilidade de construir uma afirmação associada a essa expectativa e sua negação.

Ressalta-se que o aluno deve ter o controle da situação-problema em que ele se coloca para que a tomada de consciência realmente aconteça. 


\subsection{Processo de validação}

Balacheff (1987), assim como De Villiers (2001), defende que a ausência do processo de validação, ou então um cenário propício a argumentações com fundamentações matemáticas sólidas, aparece diretamente ligada à análise que o indivíduo faz da situação em que se encontra. A avaliação do risco relativo à decisão que precisa ser tomada é parte essencial para que o sujeito desenvolva uma prova matemática. Vimos anteriormente, nos apoiando no trabalho de De Villiers (2001), que o aluno, sujeito envolvido no processo de validação, a desenvolverá conforme sinta a necessidade de argumentar sobre a afirmação, ou de validar a situação em questão. Balacheff defende a mesma ideia, afirmando que existem níveis de validação, ou seja, as afirmações são validadas de diferentes formas pelo aluno, dependendo da necessidade que este sinta de realizar testes ou verificar se a situação é sempre válida. O pesquisador defende que tais níveis aparecem nos processos de validação à medida em que são provocadas por exigências da situação.

Com base nos trabalhos de De Villiers (2001) e Balacheff (1987), podemos considerar que o sujeito não vai obrigatoriamente desenvolver justificativas com base em estruturas subjacentes para convencimento de um grupo ou dele mesmo, pode não fazer o uso de inferências lógicas, e não trabalhar com generalidade, caso não julgue como necessário. É o que o que De Villiers (2001) chama de economia de esforço. O sujeito não mobiliza senão o que é necessário para realizar a conclusão em questão. O aluno pode simplesmente acreditar na validade da informação ou do resultado encontrado sem se preocupar com a estrutura do conteúdo, por se tratar de "bons objetos" com "boas relações". Em certos casos, os alunos apenas executam algoritmos e confiam em comandos bastante utilizados em sua vida escolar. São situações em que as questões de validação não se colocam, e assim permitem a economia da validação da ação.

Nesse sentido, Sowder e Harel (1998) defendem o desenvolvimento de problemas que mostram a importância de que o aluno entenda as propriedades do sistema que está utilizando, e não somente execute algoritmos. Um dos exemplos apresentados pelos autores é:

Você pode encontrar um erro? Comece com a equação:

$x+y=-z$

Multiplique os dois lados por 4 e depois por 5, e troque os membros da segunda equação:

$4 x+4 y=-4 z$ 


$$
-5 z=5 x+5 y
$$

Adicionando as duas equações:

$4 x+4 y-5 z=5 x+5 y-4 z$.

Adicionando 9z aos dois lados, nós obtemos:

$4 x+4 y+4 z=5 x+5 y+5 z$.

Então

$4(x+y+z)=5(x+y+z)$,

O que implica que

4 = 5. (SOWDER E HAREL, 1998, p. 678, tradução nossa)

Dessa forma, o aluno percebe, após se deparar com o absurdo de que $4=5$, que deverá pensar nas propriedades e nas relações que realmente pode utilizar, levando em consideração as características do sistema numérico. Ou seja, apenas executar algoritmos pode levá-lo a contradições. Utilizando do mesmo raciocínio, o aluno, ao se deparar com alguns resultados, leva em consideração o processo de validação com o intuito de verificar a consistência de seu argumento. Segundo Balacheff (1987) caso isso não aconteça, as situações constituem a esfera da prática, pois não exigem controle das validades dos resultados obtidos. O máximo que ocorre é a percepção de erros de execução da prática.

\subsection{Processo da prova}

Balacheff (1987) cita dois tipos de situações para tomada de decisões: situação de decisão e situação de validação. Uma situação de decisão é quando não é exigido do sujeito uma argumentação por prova matemática para a tomada de decisão, sendo aceitas apenas respostas que afirmam, refutam ou preveem resultados apenas por meio de testes e práticas já conhecidas. Por exemplo, podemos perguntar ao aluno:

- A soma de dois números pares é sempre um número par?

Em uma situação de decisão, o aluno poderia simplesmente realizar alguns testes, condizentes com sua prática, e responder com base nos resultados obtidos.

De acordo com Balacheff (1987) na situação de validação é necessário que o sujeito trabalhe com o convencimento próprio ou de uma outra pessoa com base na estrutura em que 
se encontra o objeto matemático. Por exemplo, a um aluno que tem o conhecimento sobre a soma dos ângulos internos de um triângulo, podemos propor a seguinte questão:

- Qual é a soma dos ângulos internos de um pentágono?

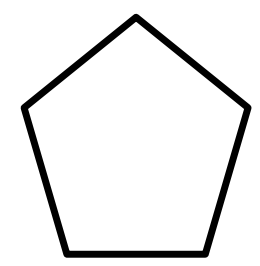

Com a atividade acima pretende-se que o aluno trabalhe com o conhecimento já adquirido sobre ângulos internos de triângulos, porém traz a necessidade do próprio convencimento sobre um novo resultado.

Segundo Balacheff (1987), no debate sobre o desenvolvimento de decisões, a necessidade de garantir uma validade ou negá-la faz com que a partir de uma situação de decisão possamos trabalhar com uma situação de validação, em que a oportunidade de desenvolvimento da habilidade de argumentar e provar seja bastante elevada.

Para Balacheff (1987), a discussão sobre decisões em atividades propostas pelo professor é considerada uma situação social, ou seja, um tipo de interação entre os estudantes sobre a validade do desenvolvimento da resposta proposta para uma determinada atividade. A interação entre os alunos é um lugar de confrontos de ideias, universos linguísticos, e de conhecimento. A produção de uma prova levando em consideração a situação social, obriga a considerar diferentes tipos de argumentos de vários interlocutores diferentes para que, finalmente seja construído um sistema de validação comum, após os debates realizados. Esse ponto de vista também é enfatizado nos trabalhos de Nasser e Tinoco (2003) e Sowder e Harel (1998).

Segundo Balacheff (1987) não podemos esperar que a situação determine o comportamento do aluno. Como professores, devemos estudar as situações em que o processo de validação esteja evidente. Basicamente a discussão se difunde com o que tratamos anteriormente como "funções da prova", porém, agora, com o processo de prova como centro da questão. Dessa forma, os tipos de argumentos utilizados por um estudante no desenvolvimento de uma prova Matemática, dependerão diretamente da necessidade que ele julga para construí-la.

Há uma dialética de validação existente nos processos de prova. O sujeito deve analisar prós e contras no processo de validação e concluir sobre possíveis contradições. Balacheff 
(1987) defende que a elaboração de uma prova passa por uma análise crítica. O autor afirma também que uma prova rigorosa e definitiva é uma prova que não será refutada.

\subsection{Das provas práticas às provas intelectuais}

Em um cenário em que o sujeito realiza testes, experiências e, como consequência, toma decisão sobre o enunciado, temos o que chamamos de validações pragmáticas da decisão, ou ainda, de provas pragmáticas ou provas práticas. Por outro lado, segundo Balacheff (1987) as provas intelectuais requerem necessariamente uma expressão linguística matemática apropriada em relação aos objetos em questão, além de necessitar de domínio sobre a estrutura em que se encontra o objeto matemático.

Balacheff evidencia as diferenças entre os dois tipos de prova dizendo que:

A natureza mesma da dialética associada a esses dois tipos de prova são fundamentalmente diferentes. Em particular, a contradição contida nos fatos não tem o mesmo status que aquela contida no discurso, mesmo que este invoque os fatos. Quanto às provas em si, elas não estabelecem da mesma forma as proposições que elas sustentam:

- a prova pragmática está comprometida com a singularidade dos eventos que a constituem, é preciso aceitar seu caráter genérico. Ela é, ademais, tributária de um contingente material: ferramentas imprecisas, falhas de funcionamento;

- a prova intelectual mobiliza um significado contra outro, uma relevância contra outra, uma racionalidade contra outra. (BALACHEFF, 1987, p. 157 , tradução nossa)

De início, os alunos que estão acostumados a realizar provas pragmáticas, usam resultados que Balacheff chama de teorema-em-ação, que não foram provados, mas sim comprovados pela prática, ou seja, concluem ou afirmam algo a partir de testes realizados ou exemplos observados. Mesmo que o sujeito coloque em questão o processo de generalização, alguns testes são suficientes para validar uma afirmação. O que acontece, na realidade, é uma dificuldade muito grande em se descolar da prática e, como consequência, trabalhar com provas intelectuais. Nas provas práticas, as operações e os conceitos utilizados se dão na ação, uma validade verificada na prática. Em geral, os alunos que se apoiam em provas práticas conhecem 
propriedades do conteúdo matemático estudado, mas não sabem justificá-las, ou utilizá-las para chegar em outras conclusões importantes. Podemos dizer que a prova prática é limitada pela ação, e não pelo conhecimento do grupo de objetos matemáticos em questão.

Como dissemos anteriormente, as provas práticas e as provas intelectuais estão necessariamente ligadas. Na realidade, há uma transição a ser estudada. Logo, ao trabalharmos com desenvolvimentos de provas práticas de nossos alunos, estamos analisando os primeiros momentos da gênese de um saber. Balacheff (1987) argumenta que os teoremas-em-ação podem significar existência de modelos implícitos, modelos construídos pela ação, modelos construídos pela prática, essenciais no desenvolvimento da linguagem (materna ou matemática) necessária para realização de provas intelectuais.

O professor, conhecedor do saber matemático e analítico de desenvolvimento de provas, pode restringir ou incentivar o acesso a provas práticas, dependendo do que o aluno pode desenvolver no momento da atividade. Um dos exemplos que Balacheff utiliza é o proporcionado pelo jogo da Corrida dos 20, proposta por Brousseau em 1975.

O jogo é organizado da seguinte maneira:

- participam duas crianças;

- o primeiro jogador escolhe um dos números, 1 ou 2;

- o outro jogador deve também escolher 1 ou 2 e somar ao número escolhido por seu adversário;

- este, soma ao total anterior mais uma parcela de valor 1 ou 2, e assim por diante;

- vence aquele que chegar ao total de 20.

De início, os alunos podem jogar sem maiores preocupações. Entretanto, a tendência é que, querendo ganhar, os estudantes passem a pensar em estratégias que garantam a vitória ao final do jogo. É neste ponto que podemos encontrar os teoremas em ação.

Com a prática, os alunos irão perceber que ganhará o jogo quem chegar em 17, já que seu adversário deverá escolher entre totalizar 18 ou 19. Qualquer que seja a escolha, o outro aluno chegará ao total 20 em sua vez.

Mas, chega ao total 17 quem antes totalizar 14. E chega ao total 14 quem antes totalizar 11 , e assim por diante. 
Bem, as crianças até podem perceber, apoiados na prática, que irá vencer quem dominar os totais $2,5,8,11,14,17,20$. Mas quais argumentos eles conseguem utilizar para explicar esse fato?

Os estudantes se encontrarão, segundo Brousseau (1975), em uma situação de analisar enunciados e classificar entre verdadeiros e falsos. Algo do tipo: "se eu totalizar 15 eu vencerei o jogo? E se eu totalizar 12?”.

As conclusões certamente se apoiarão na prática. Entretanto será algo tão claro para o aluno que podemos classificar como um verdadeiro teorema em ação. Por fim, observamos que, ao decorrer o caminho da produção de prova citada na Corrida dos 20 , temos um processo de prova explicito na atividade e uma situação de validação para conclusão sobre o enunciado verdadeiro.

Novamente, nos apegamos à passagem das provas práticas para as provas intelectuais, em que, a tomada de consciência da generalização é fundamental. Para Balacheff (1987), um passo importante no desenvolvimento de provas, é notarmos que tal tomada de consciência está, justamente, na fronteira entre as provas práticas e as provas intelectuais.

Existe um processo de passagem de um tipo de prova para o outro, em que, para que o sujeito desenvolva uma demonstração, a linguagem de familiaridade não é suficiente. É relevante que ele adquira uma linguagem funcional, ou seja, uma linguagem que dê suporte para argumentações e generalizações para um grupo de objetos matemáticos. Dessa forma, o sujeito se desprenderá do que é somente movido pela ação ou práticas de operações, e se adequará a algo que representará uma verdadeira ferramenta de cálculo individual. Para que isso ocorra, Balacheff (1987) entende ser necessário um processo de:

- descontextualização: abandono do objeto real, do lugar onde as ações são praticadas, para que se alcance uma classe de objetos que seja independente das situações singulares.

- despersonalização: um descolamento da ação do sujeito que a praticou, e dessa forma, do indivíduo de que ela deve se tornar independente.

- destemporalização: anulando a relação das operações com as suas datas de realização e duração.

Também, a passagem das provas pragmáticas às provas intelectuais, repousa sobre três polos que interagem fortemente:

- o polo dos saberes: natureza dos saberes dos alunos; 
- o polo linguístico, ou da formulação;

- o polo da validação, ou os tipos de racionalidade que sustentam as provas produzidas.

O autor resume a correspondência entre os polos apresentados segundo uma ordem hierárquica de desenvolvimento/aprendizagem da prova matemática. Observe o esquema:

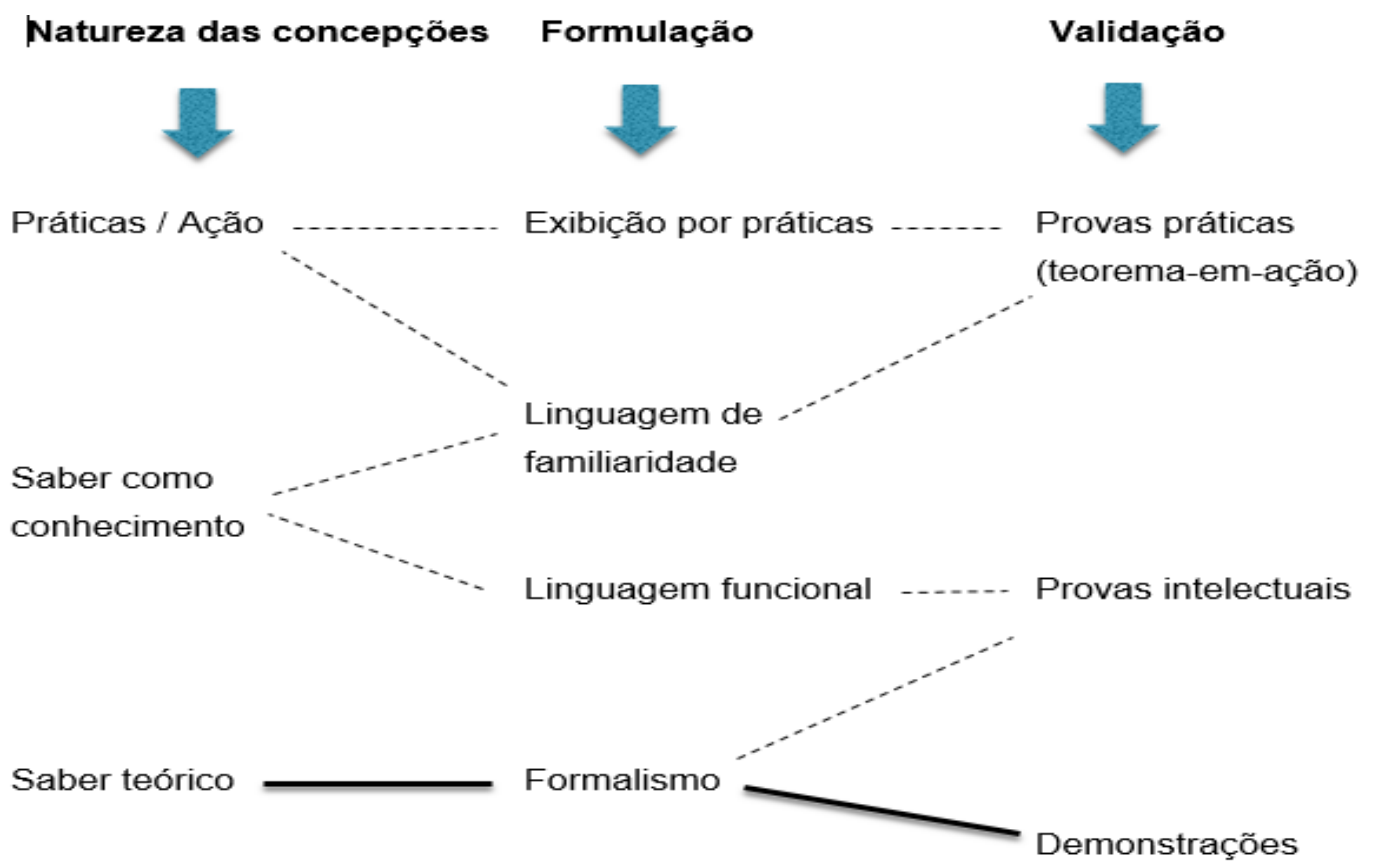

FIGURA 4 - Esquema de polos da passagem de provas proposto por Balacheff (1987)

O esquema nos ajuda a diferenciar as ideias e níveis envolvidos no processo de desenvolvimento e aprendizagem de provas matemáticas por um sujeito.

Para que possamos reconhecer pontualmente as provas práticas ou provas intelectuais apresentadas por nossos alunos, entender e saber o que podemos propor para que alcancemos o maior desempenho possível na aprendizagem de provas matemáticas, nos baseamos em alguns trabalhos que tratam desse tema. Vários pesquisadores desenvolveram teorias baseadas nos diversos tipos de argumentação e prova, desde as pragmáticas, até as demonstrações. Nesse ponto, analisamos com mais rigor os trabalhos desenvolvidos por Balacheff (1987), Sowder e Harel (1998), Rezende e Nasser (1994).

\subsection{Reconhecendo os tipos de provas}

Segundo Balacheff (1987), em relação a passagem das provas pragmáticas às provas intelectuais, nós podemos reconhecer vários tipos de provas que se diferenciam pelos saberes 
envolvidos e pela natureza da racionalidade de cada uma delas. Dos vários tipos que podem existir, o pesquisador destaca quatro que considera essenciais nesse desenvolvimento. São eles: empirismo ingênuo, experiência crucial, exemplo genérico e experiência mental. Com base em nossas leituras, definimos a frente cada uma das provas expostas por Balacheff.

- Empirismo ingênuo: é o primeiro nível de validação e se encontra entre as provas práticas. A ideia é que o aluno que se encontra neste estágio de prova tire, da observação de um pequeno número de casos, a certeza da verdade de uma afirmação. Veja a seguir o exemplo sobre o problema da quantidade de diagonais de um polígono apresentado no trabalho de Balacheff:

Lionel e Laurent enumeraram 5 diagonais num pentágono. Depois da verificação desse número em mais uma representação do pentágono, eles releram o enunciado do problema e depois concluíram:

Laurent: ... existem 5 vértices e 5 diagonais...

Lionel: sim, e a gente provou.

Eles mostram ao observador sua resolução e seu resultado. Então, este lhes propõe um hexágono. (BALACHEFF, 1987, p. 163, tradução nossa)

No Capítulo 6, em que apresentamos as respostas e análise de atividades desenvolvidas com alunos do 9o ano, evidenciamos vários casos de argumentações de mesma natureza, situações que podem ser de muito aprendizado para aluno e, também, seguramente para o professor, já que esse é o ponto em que o profissional que possui o saber matemático e o saber sobre o processo de ensino/aprendizagem de provas matemáticas deve agir para que o aluno se desprenda das argumentações construídas somente pela prática e possibilite o desenvolvimento do sujeito até que ele consiga elaborar provas intelectuais.

- Experimento crucial: é um procedimento de validação de uma afirmação em que o indivíduo coloca explicitamente o problema da generalização em questão, e faz a sua argumentação em relação a um exemplo que ele considera o menos particular possível. Dessa forma, esse processo se diferencia do empirismo ingênuo, pois neste último, o sujeito não se preocupa o problema da generalização. Porém, da mesma forma, as provas contidas no experimento crucial ainda fazem parte de um processo fundamentalmente empírico. Complementando, Balacheff diz que: 
Assim, no caso do número de diagonais de um polígono, este é o caso de um aluno que propõe sua conjectura: "a gente vai fazer uma figura imensa para verificar" (Laura); ou o caso daquele aluno que depois de "testar com 15, depois que dá certo, diz que vale para outros"(Nadine). Assim, a experiência crucial provoca um efeito sobre "o que não está presente", afirmando que "se funciona, funciona sempre”. (BALACHEFF, 1987, p. 164, tradução nossa)

- Exemplo genérico: consiste na explicitação das razões da validade de uma afirmação pela realização de operações ou análises em relação a um representante de uma classe de objetos. Nesse ponto, já são pensadas as propriedades e estruturas de toda a classe, mesmo que estudadas a partir de algo pontual. É importante ressaltar que no exemplo genérico ainda resta um apego aos nomes próprios, já que as conclusões são normalmente realizadas com a exibição de um dos seus representantes.

"Num polígono de seis vértices, de cada um saem três diagonais, totalizando 18. Mas como cada diagonal junta dois pontos, temos só 9 diagonais: 18:2=9. O mesmo vale para 7 vértices, $8,9,10,11 \ldots$ etc. (...) Lionel e Laurent experimentam abordar sua conjectura utilizando um hexágono que tem um valor de exemplo genérico em seu projeto, que vale por si, mas depois eles evoluem para uma formulação em que se apegam as marcas particulares. (BALACHEFF, 1987, p. 165, tradução nossa)

- Experiência mental: ocorre quando o sujeito retira de sua prova um representante em particular. As afirmações e conclusões não são retiradas apenas das práticas de exemplos. Ainda, na experiência mental, há notavelmente uma influência da temporalidade, mas há um tratamento genérico para o problema. Segundo Balacheff (1987), justamente na linha entre o exemplo genérico e a experiência mental, se encontram a passagem entre as provas pragmáticas e as provas intelectuais. A passagem evidencia um tratamento mais sofisticado da linguagem. Há certamente uma evolução quanto aos meios linguísticos utilizados para realização das provas. $\mathrm{O}$ autor exemplifica com a análise de uma prova:

Cristophe e Bertrand elaboram a seguinte prova: "Conhecendo o número de vértices do polígono, de cada ponto partirá (número de vértices) - (dois vizinhos + ele mesmo) [diagonais]. Então é preciso multiplicar o que foi encontrado pelo número de vértices, pois de cada um parte o mesmo número 
de diagonais. Mas contamos duas vezes cada diagonal. O número encontrado tem de ser dividido por dois para contar uma vez só cada diagonal " (BALACHEFF, 1987, p. 165, tradução nossa)

Entretanto, Balacheff deixa claro que o experimento mental ainda não é uma demonstração, já que ainda há auxilio considerável da língua materna.

Devemos considerar que existem diferentes tipos de prova nesse intervalo, e diferenciálas pelos níveis de descontextualização, despersonificação e destemporalização, além do nível de formalismo apresentado.

É extremamente relevante apresentarmos estudos de outros pesquisadores que, assim como Nicholas Balacheff, consideram diferentes tipos de prova.

Rezende e Nasser (1994), por exemplo, no trabalho kinds of argumentation used in geometry, encontraram em suas investigações a justificativa pragmática, o exemplo crucial, recorrência a uma autoridade e a justificativa gráfica. Sendo que:

- Justificativa pragmática: é identificada em situações em que o aluno valida ou não uma afirmação com base em exemplos particulares. Neste ponto, temos uma aproximação do que Balacheff chama de provas pragmáticas. Entretanto devemos considerar que o autor francês diferencia vários tipos de provas pragmáticas dependendo da linguagem matemática utilizada, e principalmente analisa se a generalização da afirmação foi colocada em questão. Assim, podemos considerar que a justificativa pragmática de Rezende e Nasser é equivalente ao empirismo ingênuo de Balacheff (1987).

- Exemplo crucial: acontece quando são realizadas conclusões a partir de exemplos que possuem estruturas e propriedades de casos gerais.

Esse tipo de prova apontado no estudo de Rezende e Nasser (1994), engloba os tipos classificados como exemplo genérico e experimento crucial apontado por Balacheff (1987).

- Recorrência a uma autoridade: ocorre quando o aluno conclui que a afirmação é verdadeira somente com base no que o professor falou, ou no que está escrito em um livro ou artigo. Mesmo em casos que a afirmação é aceita pelo estudante, a justificativa, ou seja, o porquê de a afirmação ser verdadeira pode não estar claro, pois o aluno apenas acredita nas "verdades" apresentadas pelo professor ou pelo livro didático, o que requer atenção especial com as atividades preparadas pelo professor de Matemática. 
Nasser e Tinoco (2003) em uma das diversas atividades aplicadas para alunos de Ensino Fundamental, abordam a soma dos ângulos internos de um triângulo na geometria plana.

$\mathrm{Na}$ atividade, o questionamento é proposto da seguinte forma:

Num triângulo $\mathrm{ABC}$, os ângulos $\widehat{A}, \widehat{B}, \widehat{C}$ são chamados de ângulos internos de um triângulo.

Diga se a seguinte afirmativa é verdadeira ou falsa e justifique sua resposta:

"Quando se somam os ângulos internos de um triângulo, o resultado é sempre $180^{\circ}$ ". (NASSER E TINOCO, 2003, p. 11)

Segundo Nasser e Tinoco, todos os alunos responderam que a resposta é verdadeira, mas não apresentaram argumentos que comprovem a veracidade do enunciado:

$$
\begin{aligned}
& \text { Alguns se limitaram a usar o argumento da autoridade: } \\
& \text { "é um teorema da geometria" ou "está no livro". } \\
& \text { Outros desenharam um triângulo equilátero e somam: } \\
& 60^{\circ}+60^{\circ}+60^{\circ}=180^{\circ} \text { (NASSER E TINOCO, 2003, p. 11) }
\end{aligned}
$$

Por fim, as autoras sugerem a utilização de justificativas por meio de dobraduras, recorte ou Representação em malha quadricular. Por outro lado, os alunos mais experientes deverão ser incentivados ao interesse pela prova, que depende do Teorema das paralelas cortadas por uma transversal. Entretanto:

Esta demonstração deve ser apresentada somente a alunos que sejam capazes de chegar a ela, sozinhos, ou, ao menos, consigam compreendê-la. A linguagem utilizada é adequada para professores, mas nem sempre faz sentido para os alunos. (NASSER E TINOCO, 2003, p. 11).

- Justificativa gráfica: acontece quando o aluno justifica a veracidade de uma afirmação a partir de uma imagem. No trabalho de Nasser e Tinoco (2003), baseado nos tipos de provas encontrados por Rezende e Nasser (1994), as autoras citam o seguinte exemplo:

$$
\text { Explique por que }(a+b)^{2}=a^{2}+2 a b+b^{2}
$$


Justificativa apresentada por alunos de $7^{\mathrm{a}}$ série que ainda não dominavam os produtos notáveis:

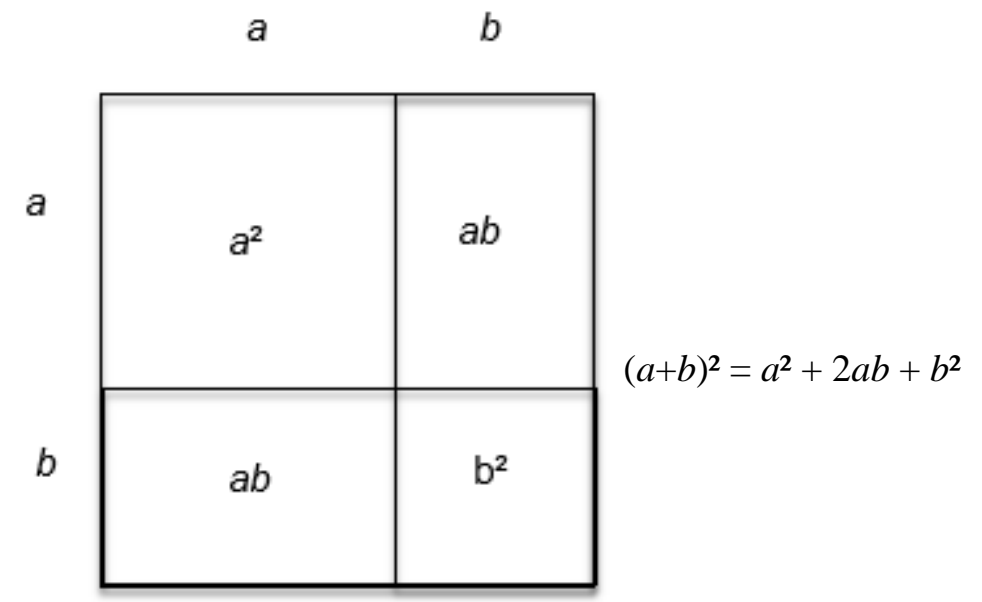

(NASSER E TINOCO, 2003, p. 6)

Por fim, as autoras fazem a observação de que:

Dependendo da faixa etária e do nível de raciocínio dos alunos, o professor deve aceitar e, até mesmo, estimular justificativas desse tipo. (NASSER E TINOCO, 2003, p. 6)

A classificação de tipos de prova apresentada por Rezende e Nasser (1994), apesar de diferente da classificação feita por Balacheff (1987), tem vários pontos em comum. Ambos os trabalhos apontam para uma aceitação, pelo professor, de vários tipos de provas possíveis para um aluno e para a importância de proporcionar formas de fazer esse estudante caminhar no sentido de passar para tipos mais "maduros" e cada vez mais próximo de uma prova formal.

Outra obra de extrema relevância para a pesquisa em argumentação matemática é apresentada pelos americanos Sowder e Harel (1998). A partir de análises de justificativas de resultados matemáticos de estudantes, os autores desenvolveram uma tipologia de prova que prevê diversos tipos de argumentação, e que certamente contribui não só para pesquisadores da área, mas principalmente para professores de Matemática. Sowder e Harel partiram da ideia de que a atual abordagem em relação a provas matemáticas não vem obtendo sucesso, tanto com alunos da escola secundária (equivalente, no Brasil, ao Ensino Médio), quanto com estudantes de curso superior. Em nossas leituras, o que primeiramente nos chamou atenção, foram as frases que os autores utilizaram para exemplificar o que acontece no ensino de Matemática em relação a prova. Em um dos artigos que lemos, Types of students' justifications, Sowder e Harel (1998, 
p. 1, livre tradução), é iniciado com as seguintes frases: "Eu apenas sei isso"; "A senhora Flores disse isso para nós no ano passado"; "Vocês podem ver isso através do desenho"; "Eu fiz alguns exemplos"; "Nosso grupo encontrou um padrão"; "Eu acho que eu tenho uma prova". Tais pronunciamentos são extremamente semelhantes aos que observados com nossa pesquisa envolvendo alunos do Ensino Fundamental, e também ao que lemos de pesquisas que envolvem professores da Educação Básica, tanto no Brasil, como em outros países. O que temos é um desafio universal, um problema em comum, que é independente do sistema de ensino de cada região.

Nos concentrando na tipologia desenvolvida por Sowder e Harel (1998), podemos dizer que os autores separam as justificativas apresentadas em três esquemas de provas:

- esquemas de provas baseadas externamente;

- esquemas de provas empíricos;

- esquemas de prova analíticos.

Cada um desses esquemas ainda é dividido em subcategorias que serão apresentadas a seguir. Antes de começarmos a analisar toda a tipologia, é importante deixar claro que na base das argumentações sobre cada esquema, os autores defendem que não são considerados, de maneira alguma, hierárquicos. A mesma pessoa pode argumentar no âmbito de diferentes categorias em diferentes tempos e contextos, o que vai ao encontro das teses de outros pesquisadores apresentados até aqui. Trazemos, neste momento, a ideia geral das categorias e subcategorias desenvolvidas e apresentadas por Sowder e Harel:
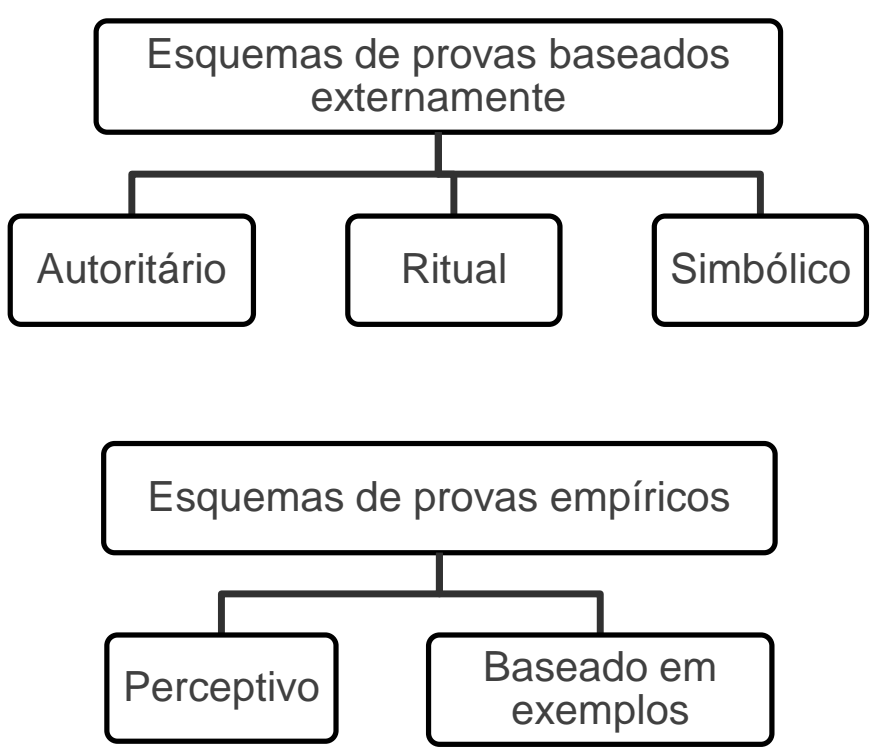


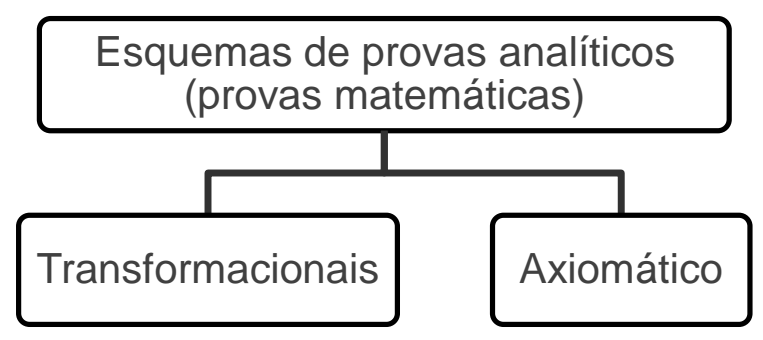

FIGURA 5 - Esquemas de provas apresentados por Sowder e Harel.

Podemos definir os esquemas de Sowder e Harel (1998) da seguinte forma:

- Esquemas de provas baseados externamente: é onde se encontram os casos em que o estudante é convencido por declarações de fora da sua própria argumentação. Notamos que o aluno pode ser convencido, por exemplo, pela declaração de um professor, um texto e conclusões de um livro, ou ainda por um processo algébrico cujo significado o aluno não entende, mas mesmo assim utiliza.

A primeira subcategoria que vamos analisar é o esquema de prova autoritário. Nas justificativas que estão presentes nesse esquema, o estudante acredita fielmente nas declarações de um professor, nas conclusões e textos de livros de Matemática, ou ainda em um colega de classe que se mostra mais conhecedor do que ele. As justificativas não são questionadas quanto à sua validade e, consequentemente, problemas como o da contradição, por exemplo, não são questionados. Sowder e Harel (1998) trazem algumas declarações e pequenas análises que evidenciam tal situação:

- Eu tenho que ver se eu posso encontrar isso em um livro" ou "eu não lembro" - ou até uma rejeição de um valor da prova -"Eu pulei as provas, uma vez que os resultados que são importantes" - são os piores efeitos de uma dependência exclusiva na autoridade (SOWDER E HAREL,1998, p. 67, tradução nossa)

Os autores dizem que as provas desenvolvidas nesse esquema não são de todo ruim, tendo em vista que até matemáticos consagrados utilizam resultados de outros especialistas, muitas vezes sem desenvolver as argumentações para validar as conclusões apresentadas. Mas, o grande problema se encontra nos casos em que os estudantes têm esse esquema de prova como o único meio de argumentação.

Como possibilidade de auxílio aos estudantes, Sowder e Harel (1998) sugerem que o professor estimule os trabalhos em grupo, as discussões, para que o estudante perceba que os 
resultados não estão prontos, e as conclusões são geradas por meio de argumentação. A ideia é fazer com que o professor ou livro deixem de ser o único foco de respostas e conhecimento.

Já as provas e justificativas de estudantes que se apoiam no esquema de prova ritual, analisam unicamente a forma do argumento, o que faz com que o raciocínio argumentativo não seja questionado. O estudante decora um "estilo" de prova, e depois utiliza unicamente do mesmo ritual, sem considerar argumentações via raciocínio lógico. Isso pode fazer com que o aluno refute qualquer outro tipo de prova apresentado que não esteja no modelo conhecido. Sowder e Harel (1998) sugerem que outros tipos de provas sejam apresentados aos alunos, para que dêm valor às argumentações, sem fazer com que as provas já conhecidas percam a sua validade.

A última subcategoria dos esquemas de provas baseados externamente é o esquema de prova simbólico, que acontece quando o estudante utiliza símbolos matemáticos sem considerar suas propriedades, ou quando os desenvolvem argumentos com símbolos como se eles tivessem uma vida independente de qualquer significado ou qualquer relação com as quantidades na situação que envolve a argumentação. Segundo os autores, esse é o lado ruim do esquema de prova simbólico. Esse tipo de esquema de raciocínio simbólico permite reagir a:

$\begin{array}{ll} & \frac{a}{b}+\frac{c}{d} \\ & \frac{a+c}{b+d}, \\ \text { com } & (a+b)^{2} \\ \text { ou ainda, a: } & a^{2}+b^{2} .\end{array}$

Para o estudante no esquema de prova simbólico, a argumentação é baseada somente no processo simbólico. Ao se depararem com a expressão $(a+b)^{2}$ os alunos encontram como resposta o binômio $a^{2}+b^{2}$ sem preocupação com a veracidade da afirmação para todo o sistema numérico. Não há ligação entre as estruturas do sistema numérico e as expressões analisadas.

As expectativas para as afirmações algébricas podem ajudar no processo, ou seja, alguns testes podem ser realizados com a intenção de encontrar contradições e, consequentemente, evidenciar que as generalizações possuem erros conceituais. 
Segundo Sowder e Harel (1998), existe um lado bom quanto ao esquema de prova simbólico, que é o conhecimento do poder dos símbolos. Ao resolver um sistema de equações lineares para um problema, independentemente da área de aplicação, não é necessário adicionar à resolução um significado em todas as etapas do processo. Isso mostra o poder dos símbolos para o estudante, principalmente em álgebra.

- Esquemas de provas empíricos: as provas nesse esquema são, em geral, onde estão classificadas as provas baseadas unicamente na resolução de alguns exemplos. Antes de apresentar as subcategorias, os autores deixam claro que a ideia de se basear em exemplos ocorre em todos os níveis, e em todas as áreas da ciência. Matemáticos profissionais fazem isso, para depois generalizar as ideias a partir de testes para vários casos. O problema e a discussão nesse caso é quando as provas são baseadas unicamente em exemplos, ou seja, toda a argumentação é feita por casos particulares.

A primeira subcategoria nesse tipo de prova é o esquema de provas perceptivo. Ocorre na maioria das vezes em geometria, quando o aluno, somente a partir de percepções das características dos desenhos, faz conclusões. Ocorre também quando o estudante tenta convencer outras pessoas de resultados objetivos unicamente através das figuras. Sowder e Harel (1998) citam um exemplo que deixa bem claro quão perigoso é esse tipo de prova:

Por exemplo, em uma prova que segmentos conectando os pontos médios dos lados de um trapézio isósceles formam um losango, uma estudante do "college" consistentemente desenhou um quadrado como o trapézio isósceles dela e com base nisso usando os ângulos retos ela mostra o perigo de fazer conclusões com base em um desenho. (SOWDER E HAREL, 1998, p. 672 , livre tradução)

Há um perigo nas provas realizadas com base unicamente em desenhos, pois tais ilusões de ópticas podem levar para uma conclusão errônea. Segundo os autores, um grande auxiliador para amenizar esse problema é o uso da tecnologia durante as aulas de Matemática, mais precisamente de geometria. As alterações nas figuras podem ser feitas de forma rápida e dinâmica, oferecendo análise de vários casos, além de um raciocínio baseado em muitas manipulações do desenho. Outra possibilidade é, novamente, trabalhar geometria com pequenos grupos de alunos, pois isso permite que um estudante alerte o outro para possíveis erros na argumentação, tal como propor outros tipos de justificativa em que um estudante, sozinho, não teria pensado. 
Outra subcategoria dos esquemas empíricos de provas é o esquema de provas baseado em exemplos. Nesse ponto de prova, o estudante se convence e tenta convencer outras pessoas avaliando uma conjectura obtida por um ou mais exemplos. $\mathrm{O}$ grande problema diagnosticado por Sowder e Harel para estudantes que realizam provas que se encontram nessa subcategoria é nos casos em que os padrões anteriormente encontrados não são mais observados depois de um estudo mais abrangente. Os autores citam algumas questões que podem levar o estudante a fazer conjecturas equivocadas por conta dos padrões encontrados. Citaremos aqui, duas dessas questões e faremos a análise do risco em cada uma delas.

Questão 1: É verdade que para todo $n$ natural, o número $n^{2}-79 n+1601$ é primo?

Na questão acima, para $n=0, n=1$ ou $n=10$, obtemos números primos como resultados. Mas isso não acontece para $n=80$, por exemplo. O que mostra que a possível conjectura que o estudante faça aplicando dois ou três números na expressão apresentada não para outros casos não testados.

Questão 2: O número obtido na expressão $1141 n^{2}+1$ é um quadrado perfeito para algum $n$ inteiro positivo?

Neste caso, o erro na conjectura é ainda mais difícil de ser analisado, pois para $n=1$, $n=2, n=3, \ldots, n=30693385322765657197397207$, pelos testes realizados em softwares, não obtemos um quadrado perfeito. Porém para qualquer inteiro maior que esse último citado, a expressão resulta em um quadrado perfeito. Em casos como esse, notamos que não podemos ter confiança unicamente nos padrões encontrados, independentemente do número de testes que são feitos. Porém, devemos nos atentar para o valor de provas realizadas por conjecturas, tendo em vistas que teoremas são descobertos a partir de conjecturas, para depois serem demonstrados rigorosamente. O processo de observação de padrões é realizado por matemáticos profissionais e são valiosíssimos, não só para estudantes, mas para toda a comunidade matemática. Segundo Sowder e Harel (1998), o problema aparece no momento em que os padrões são utilizados unicamente como justificativa para uma questão. 
Por exemplo, aos alunos do 7ํㅜ ano do Ensino Fundamental, com a introdução dos polinômios de $2^{2}$ grau, podemos propor a questão:

É verdade que $x^{2} \leq 2 x+50$ para todo $x \in \mathbb{Z}$ ?

Os alunos podem observar que para $x=1,2,3,4,5,6$ a desigualdade é verdadeira e, dessa forma, afirmar positivamente. Entretanto, o mesmo não é verdade, por exemplo, para $x=50,51$ ou 60.

No caso de estudantes que realizam provas que se encontram no esquema de provas baseado em exemplos, segundo Sowder e Harel (1998), o professor deve, como tentativa de estimular novas justificativas, apresentar exemplos como os vistos anteriormente, e assim os estudantes tendem a perder a impressão de que padrões são sempre seguidos.

- Esquemas de provas analíticos: segundo os autores, provavelmente os professores de Matemática consideram provas que são estão nesse esquema como sendo as melhores justificações matemáticas desenvolvidas pelos estudantes. Esse esquema de provas contém dois subtipos, apresentados a seguir.

No esquema de prova transformacional, estão as provas em que os estudantes utilizam as justificativas com raciocínio baseado em padrões encontrados a partir de testes realizados ou uma série de observações. Mas, diferentemente do esquema de prova empírico, mais precisamente no esquema de prova baseado em exemplos, o aluno entende perfeitamente a estrutura que está por trás dos padrões. Um exemplo que deixa bem clara a diferença entre os dois tipos de prova é o seguinte:

- $\quad$ Tarefa: Encontre um atalho para obter o quadrado de um número de final 5.

$$
\begin{gathered}
15^{2}=225 ; 25^{2}=625 ; 35^{2}=1225 ; 45^{2}=2025 ; 55^{2}=3025 ; \\
65^{2}=? \\
75^{2}=?
\end{gathered}
$$




$$
(n 5)^{2}=?
$$

Um aluno, para responder a questão acima, pode apresentar diversos tipos de justificativas. Uma delas, por exemplo, é a de verificar que basta analisar a base da potência, elevar a dezena ao quadrado, multiplicar o resultado por cem, somar a esse valor a própria dezena multiplicada por 100 e, ao final, o resultado deve ser somado com 25 . Por exemplo $35^{2}$, como a dezena é 3 , então temos que $35^{2}=3^{2} \cdot 100+3 \cdot 100+25=1225$. De modo análogo, $45^{2}$ $=4^{2} \cdot 100+4 \cdot 100+25=2025$. Em casos como esse, nota-se que o padrão é considerado como uma regra, e o que está por trás desse padrão não é analisado ou questionado. Dessa forma, as justificações desse tipo se encontram no esquema de prova baseado em exemplos. Mas, caso o estudante note que a solução para o problema pode ser pensada e baseada na expressão $(10 n+5)^{2}$, além de observar o mesmo padrão, há a grande descoberta do que há por trás do padrão, entendendo matematicamente o que está acontecendo para a solução do problema. Nesse caso, as justificativas são consideradas como um esquema de prova transformacional.

As provas que se baseiam em esquemas de provas axiomáticas utilizam um corpo de conhecimento organizado por resultados subsequentes obtidos por uma consequência lógica. $\mathrm{O}$ sistema desse tipo de prova envolve definições, axiomas e teoremas. Sowder e Harel (1998) citam a Geometria Euclidiana como um ótimo exemplo de um sistema que envolve tais justificativas e onde há mais possibilidade de êxito para o estudante trabalhar confortavelmente. Esse tipo de prova é o esperado pela maioria das pessoas envolvidas com ensino de Matemática, seja no Ensino Básico, ou seja, no Ensino Superior.

Podemos observar, analisando os trabalhos de Rezende e Nasser (1994), Balacheff (1987) e Sowder e Harel (1998), que apesar estudarmos diversos tipos de prova que podem ser desenvolvidas por estudantes de Matemática, as pesquisas apresentam classificações de provas distintas. O mais interessante é que em nossa pesquisa de campo conseguimos observar exemplos de provas semelhantes aos tipos de provas apresentados por esses autores, o que nos mostra que tais trabalhos, apesar de apresentarem pensamentos diferentes em alguns pontos, se complementam. Pensando dessa forma, as diferenças dos trabalhos desses autores, ao invés de causar contradição, colocam em exposição o grande campo de pesquisa referente ao desenvolvimento de prova matemática por alunos da Educação Básica e, certamente, enriquecem a análise do professor que se empenha em estudá-las com rigor. A seguir, apresentamos um quadro comparativo das diferentes classificações de tipos de prova encontrados nos trabalhos analisados. Vejamos: 


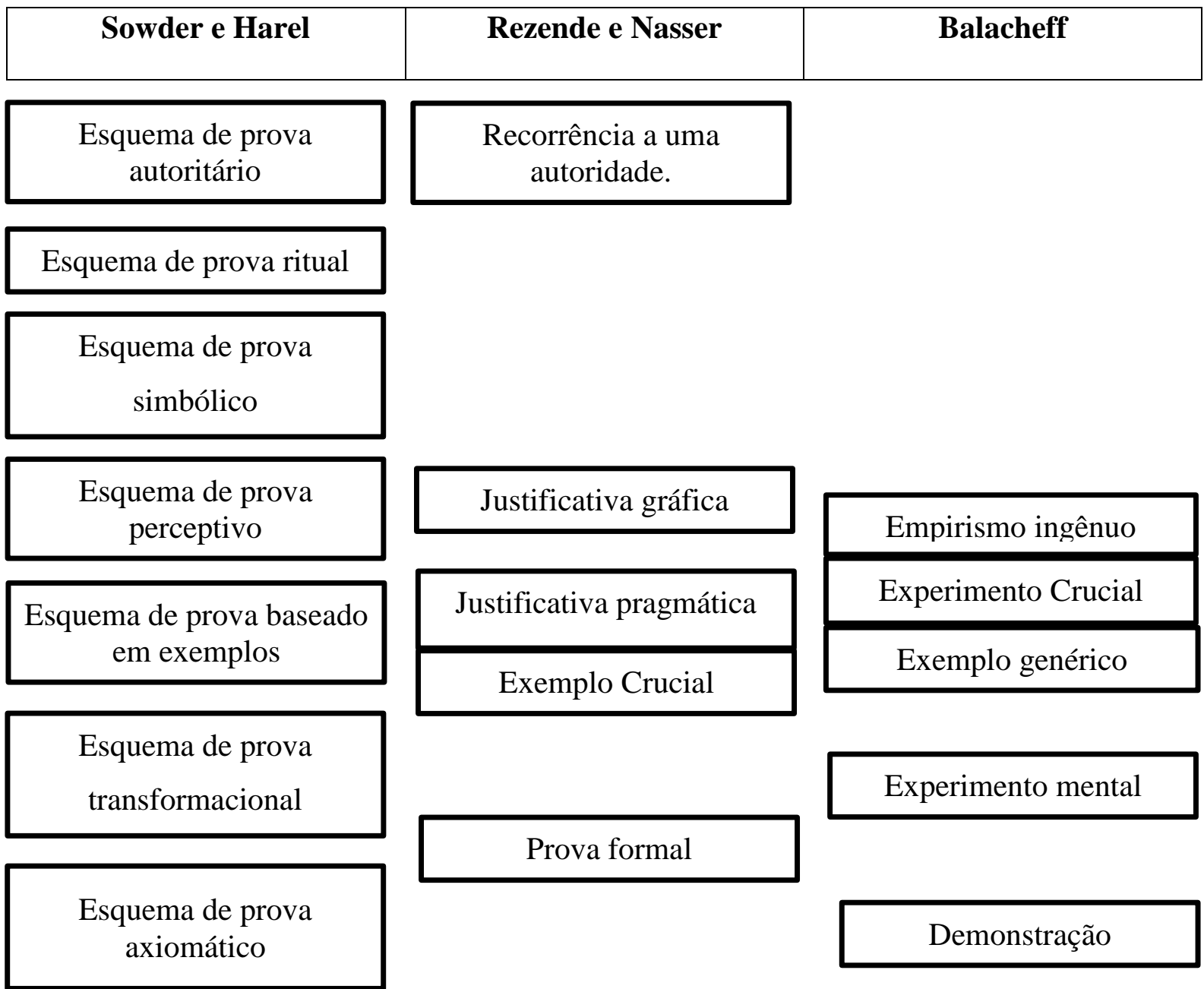

TABELA 3 - Comparação entre as tipologias de prova.

A tabela acima mostra que as tipologias de provas estudadas se relacionam em grande parte das análises. Tivemos o privilégio de perceber esse ponto crucial tanto na teoria, por meio dos artigos e trabalhos publicados de Sowder e Harel (1998), Balacheff (1987) e Rezende e Nasser (1994), quanto por meio de nossa prática com a pesquisa de campo, cujo resultados estão evidenciados no Capítulo 6.

Voltamos à tarefa:

- Encontre uma regra para obter o quadrado de um número de final 5.

Segundo Sowder e Harel (1998), caso o aluno desenvolva respostas do tipo: $45^{2}=100 \cdot 4^{2}$ $+100 \cdot 4+25=2025$, o que temos é uma prova contida no esquema de prova empírico. Mas caso o aluno, de alguma forma, demonstre que percebeu a relação entre os algarismos e escreva algo como: $65^{2}=100 \cdot 6^{2}+100 \cdot 6+5^{2}$, mesmo que não se escreva $(10 n+5)^{2}$, Balacheff $(1988)$ 
classifica como um exemplo genérico, em que considera que o exemplo obtido representa toda a classe de objetos estudada, sendo assim a prova está, na realidade, especificamente em uma transição entre provas pragmáticas e provas intelectuais. Já para Rezende e Nasser (1994), o que temos é um exemplo crucial, pois o raciocínio, apesar de buscar representar toda a classe de objetos, não representa uma generalização. Ou seja, apesar de a tipologia de provas apresentada por Sowder e Harel abrir um leque de opções para análise e desenvolvimento de provas apresentadas por nossos estudantes, acreditamos que, em muitos casos, as tipologias de provas apresentadas por Balacheff ou Rezende e Nasser complementam as análises e nos permitem aprofundar na questão e, consequentemente, nas maneiras que os professores de Matemática devem agir com o intuito de desenvolver as habilidades referentes a prova matemática em cada estudante.

Em nossa pesquisa de campo, é claro, utilizamos as tipologias citadas anteriormente como base para análises e nossas ações em relação as provas matemáticas apresentadas pelos alunos.

Usaremos cada classificação de acordo com a argumentação ou prova que o aluno apresentar, escolhendo a referência bibliográfica que, ao nosso ver, propicie a melhor compreensão da situação e proponha melhor ação. Por exemplo:

- Em situações que envolvem argumentações do tipo: porque meu professor disse isso, ou ainda, porque li em uma apostila, usaremos as tipologias de Rezende e Nasser (1994) ou Sowder e Harel (1998), já que as pesquisas que lemos de Balacheff não consideram as provas em que os estudantes se apoiam somente no discurso de uma autoridade.

- Em situações onde os estudantes apresentam provas baseadas em exemplos, recorreremos ao trabalho desenvolvido por Balacheff (1987), pois o pesquisador apresenta vários "subtipos" de provas nesse contexto, e acreditamos que, dessa forma, podemos planejar melhor as ações que devemos considerar em cada caso.

Por fim, deixamos claro que, em alguns casos, utilizamos mais de uma referência bibliográfica ao mesmo tempo, por acreditarmos ser conveniente compará-las para análise da atividade desenvolvida pelo aluno, sempre com o intuito de compreensão e ações a serem realizadas a partir de nossos resultados tabulados. Outro ponto importante que levamos em consideração, é a contribuição que cada obra fornece, dependendo do tipo de prova produzida 
pelos estudantes, para intervenções ou elaboração de atividades que propiciem a melhora do nível de argumentação de nossos alunos. 


\section{O planejamento da pesquisa}

Neste capítulo, apresentamos a organização de um estudo experimental realizado com os alunos de Ensino Fundamental. Primeiramente fizemos a escolha da metodologia para que planejássemos os passos seguintes com base na teoria adotada. Em seguida, fizemos a análise da base curricular proposta pelo município de Barueri, e também do material utilizado pelos alunos da cidade na época em que fizemos a pesquisa.

\subsection{Metodologia de pesquisa}

Essa pesquisa é qualitativa e adotamos algumas características do Design Experiments (Experimento Planejado) como opção metodológica. Segundo Cobb et al (2003), o objetivo da metodologia Design Experiments é analisar processos de aprendizagens e significados construídos pelos estudantes quando em contato com ambientes de ensino de Matemática. Essa metodologia representa uma "ecologia de aprendizagem", um sistema complexo que envolve diversos elementos de tipos e níveis distintos. Um dos motivos da escolha do Design Experiments, é que ela permite repensar as práticas adotadas no início da pesquisa, de modo intervencionista, possibilitando a elaboração e aplicação de novas tarefas ao longo da pesquisa.

Para Karrer (2006), a metodologia de Design Experiments pode ser considerada ao mesmo tempo prática e teórica, pois o pesquisador deve planejar as atividades direcionadas aos alunos, oferecendo sugestões de adaptações a novas circunstâncias, além de possibilitar a geração e testes de novas hipóteses e levar em consideração o discurso a ser desenvolvido, tais como as regras de participação, ferramentas e materiais utilizados nas atividades.

Design Experiments podem ocorrer entre professor-pesquisador e um grupo restrito de estudantes, ou ainda com aplicações realizadas em classes mais numerosas. Nesse aspecto, a segunda opção se aplica ao que propomos no presente trabalho.

Cobb et al (2003), argumentam que a metodologia dos Design Experiments possui características transversais que são indispensáveis ao compará-la e diferenciá-la de outras, 
sendo que algumas dessas características foram fundamentais para o desenvolvimento de nosso trabalho. São elas:

- Desenvolvimento tanto de uma classe de teorias do processo de aprendizagem quanto dos significados que dão suporte a aprendizagem como, por exemplo, normas negociadas e adotadas, materiais utilizados ou práticas de ensino. Neste trabalho, analisamos o que o estudante está desenvolvendo em termos de argumentação matemática, em conjunto com as práticas utilizadas que darão suporte a esse desenvolvimento.

- A metodologia é de natureza intervencionista. A pesquisa deve conter uma base inicial para que sejam possibilitadas futuras modificações. É característica do Design Experiments a busca por novas possibilidades de aprendizagem, visando mudanças na prática atual. Esta segunda caraterística nos forneceu oportunidade de repensar a elaboração e a realização das atividades e práticas de ensino possibilitando a aproximação do aluno a uma melhor aprendizagem.

- Em Design Experiments são considerados dois aspectos: prospectivos e reflexivos. No aspecto prospectivo, o experimento é realizado através de uma hipótese sobre o processo de aprendizagem e os meios utilizados para suportá-los. Já no aspecto reflexivo são realizados diversos níveis de análises, em que o professor-pesquisador faz conjecturas e as hipóteses poderão ser confirmadas ou refutadas. É importante considerar que, ao refutar uma hipótese, novas hipóteses alternativas poderão surgir e serem testadas. Inicialmente, tínhamos as hipoteses de que devíamos levar em consideração a descoberta de padrões e a realização de conjecturas dos alunos. Durante o trabalho, notamos que notas hipóteses poderian ser formuladas para que aprimorassemos nossa pesquisa.

- É uma metodologia pragmática. Durante o processo diversas teorias podem ser desenvolvidas, porém como estão relacionadas a um aspecto pontual do processo de aprendizagem e desempenham um trabalho real, são consideradas modestas.

Para utilizar algumas características da metodologia, foi importante seguirmos alguns "passos" na elaboração da pesquisa. Iniciamos por uma coleta de dados dos estudantes, tanto socioeconômico quanto do ponto de vista do conhecimento já adquirido por eles com relação a argumentação e prova, com o objetivo de desenvolver novos métodos de aprendizagem. Em sequência, definimos a trajetória e as atividades que desenvolveríamos com nossos alunos, com 
o objetivo de ter um projeto em que pudéssemos realizar testes de possíveis atividades que auxiliem no desenvolvimento da habilidade do aluno na questão do argumentar e provar no contexto matemático.

\subsection{Escola escolhida para desenvolvimento das atividades}

Por conhecer a proposta de trabalho da escola, planos anuais e mensais de ensino, decidimos por realizar a pesquisa na EMEF Sandro Luiz Braga, de período regular, situada no município de Barueri.

A escola fica em uma região periférica, cerca de $8,1 \mathrm{~km}$ de distância do centro da cidade. Recebe crianças desde o início do Ensino Fundamental I, até o término do Ensino Fundamental II. Conta com cerca de 20 docentes. Pelo que consta no Projeto Político-Pedagógico de 2016, a escola recebe, em geral, alunos de famílias enquadradas nas classes socioeconômicas C, D ou E.

O IDEB (Índice de Desenvolvimento da Educação Básica) da escola para 8oe e 9oanos, em 2015, foi de 4,5. Desempenho abaixo da média do município de Barueri que foi avaliado com o IDEB 5,2.

Decidimos fazer a pesquisa com os alunos do $9^{\circ}$ ano A que estudam no período matutino. A escolha do 9o ano foi aleatória, já que trabalhamos com 8oㅡ e 9oa anos.

Acreditamos ser melhor escolher apenas uma classe de alunos para podermos focar na análise com mais objetividade. Outro ponto que nos levou a escolher uma turma sem nenhum tipo de seleção de alunos é porque não teríamos problema em trabalhar com um grupo homogêneo, em que o "gostar de Matemática", e interesse pela matéria poderiam tendenciar os nossos resultados. A turma escolhida tinha 24 alunos, e aplicamos as atividades para todos os estudantes presentes.

Seguindo com o diagnóstico da classe, a busca pelo conhecimento e análise das características da turma, fez com que levantássemos as seguintes perguntas:

- Quais habilidades trabalhadas e temas de Matemática abordados durante o ano letivo?

- Qual é a contribuição que o material utilizado durante as aulas de Matemática fornece em relação ao desenvolvimento das habilidades de argumentar e provar? 


\subsection{Análise da base curricular e material didático}

Primeiramente, analisamos a base curricular utilizada por todas as escolas Municipais de Barueri, durante o ano de 2016.

A base curricular de Barueri é o único documento que estabelece uma relação entre os conteúdos a serem trabalhados e as habilidades que deverão ser desenvolvidas pelos alunos do município. O professor de Matemática recebia também, na época da pesquisa, a apostila trimestral e um livro didático. Podemos verificar neste documento, que poucas atividades estão voltadas para desenvolvimento de provas ou argumentações matemáticas, mesmo que a base trimestral contemple temas propícios para argumentação e prova. Por exemplo, no caso de equações de $2^{\underline{o}}$ grau (conteúdo proposto para o $9^{\circ}$ ano - $2^{\circ}$ trimestre), temos a necessidade e o uso habitual de generalizações, que certamente exigiriam validações e verificações e descobertas. Na realidade, teríamos atividades propícias ao incentivo de situações contendo processos de provas.

A falta da proposta de desenvolvimento da habilidade de argumentação e prova que ocorre, por exemplo, no $2^{\underline{o}}$ trimestre do $9^{\underline{0}}$ ano, na realidade, não é um caso isolado. Ao estudarmos as bases trimestrais do 6ํㅜ, 7ํe e 8oㅡ, verificamos que não há algum tipo de menção à argumentação ou prova matemática.

Não encontramos na proposta oficial indicação ou recomendação ao professor de que ele deva trabalhar no desenvolvimento de tais habilidades em algum momento do Ensino Fundamental. Essa omissão, poderia ser interpretada uma falha, já que o desenvolvimento da argumentação deve permear todos os conteúdos matemáticos.

Professores com boa formação, cientes da importância do desenvolvimento do raciocínio dedutivo, tendem a trabalhar nesse sentido, mesmo que os documentos oficiais não mencionem essa necessidade. Entretanto, a omissão pode também deixar uma parcela dos professores à vontade para ministrarem aulas de modo superficial, não trabalhando o desenvolvimento de argumentação e provas matemáticas e, apenas focando em fórmulas e procedimentos.

A seguir, apresentamos como exemplo a base curricular, do $2^{\circ}$ trimestre $-9^{\circ}$ ano utilizada pelos professores de Matemática de Barueri no ano de 2016. 


\begin{tabular}{|c|c|c|}
\hline $2^{\circ}$ Trimestre & Habilidades & Conteúdos \\
\hline \multirow[t]{3}{*}{$\begin{array}{l}\text { Números e } \\
\text { operações }\end{array}$} & $\begin{array}{l}\text { 1.1. Reconhecer se a equação do } 2^{\circ} \\
\text { grau dada é completa ou } \\
\text { incompleta. } \\
\text { 1.2. Identificar os coeficientes a, b e } \\
\text { c de uma equação do } 2^{\circ} \text { grau. } \\
\text { 1.3. Resolver equações do } 2^{\circ} \text { grau } \\
\text { incompletas. } \\
\text { 1.4. Encontrar o discriminante de } \\
\text { uma equação do } 2^{\circ} \text { grau e } \\
\text { relacioná-lo com o número de } \\
\text { raízes existentes. } \\
\text { 1.5. Encontrar as raízes de uma } \\
\text { equação do } 2^{\circ} \text { grau completa, } \\
\text { utilizando a fórmula resolutiva } \\
\text { (Bhaskara). } \\
\text { 1.6. Relacionar a soma e o produto } \\
\text { das raízes de uma equação com } \\
\text { seus coeficientes. } \\
\text { 1.7. Encontrar as raízes de uma } \\
\text { equação do } 2^{\circ} \text { grau, por meio de } \\
\text { soma e produto. } \\
\text { 1.8. Encontrar as raízes de uma } \\
\text { equação do } 2^{\circ} \text { grau, quando } \\
\text { possível, por meio de fatoração. } \\
\text { 1.9. Resolver situações-problema } \\
\text { envolvendo equações do } 2^{\circ} \text { grau. }\end{array}$ & $\begin{array}{l}\text { 1. Equação do } 2^{\mathbf{0}} \text { grau. } \\
\text { - } \quad \text { Equações completas do } 2^{\circ} \\
\text { grau. } \\
\text { - } \\
\text { Equações incompletas do } \\
2^{\circ} \text { grau. } \\
\text { - } \quad \text { Resolução de equações } \\
\text { incompletas do } 2^{\circ} \text { grau. } \\
\text { - } \text { Resolução de equações } \\
\text { completas do } 2^{\circ} \text { grau de } \\
\text { diferentes modos: } \\
\checkmark \text { Fórmula resolutiva. } \\
\checkmark \text { Soma e produto. } \\
\checkmark \text { Fatoração. }\end{array}$ \\
\hline & $\begin{array}{l}\text { 2.1.Identificar uma equação } \\
\text { biquadrada e reduzi-la a uma } \\
\text { equação do } 2^{\circ} \text { grau. } \\
\text { 2.2.Compreender que na equação } \\
\text { biquadrada pode haver até quatro } \\
\text { raízes distintas. } \\
\text { 2.3.Encontrar as raízes de uma } \\
\text { equação biquadrada. }\end{array}$ & $\begin{array}{l}\text { 2. Equações biquadradas } \\
\text { ou redutíveis. }\end{array}$ \\
\hline & $\begin{array}{l}\text { 3.1.Reconhecer e resolver equações } \\
\text { irracionais. }\end{array}$ & 3. Equações irracionais. \\
\hline
\end{tabular}




\begin{tabular}{|c|c|c|}
\hline \multirow{2}{*}{$\begin{array}{l}\text { Tratamento da } \\
\text { informação }\end{array}$} & $\begin{array}{l}\text { 1.1. Construir gráficos de setores } \\
\text { compreendendo que o todo equivale a } \\
\text { 100\%. } \\
\text { 1.2.Construir gráficos de setores a } \\
\text { partir de informações contidas em } \\
\text { textos ou tabelas. } \\
\text { 1.3. Relacionar informações contidas } \\
\text { em gráficos e tabelas. }\end{array}$ & $\begin{array}{l}\text { 1. Construções gráficas. } \\
\text { - Construção de um gráfico } \\
\text { de setores a partir de } \\
\text { porcentagens. }\end{array}$ \\
\hline & $\begin{array}{l}\text { 2.1.Estimar possibilidades e verificar } \\
\text { as chances de ocorrência de um certo } \\
\text { acontecimento. } \\
\text { 2.2.Expressar probabilidades por meio } \\
\text { de razões, números decimais ou } \\
\text { porcentagens. }\end{array}$ & 2. Probabilidade. \\
\hline
\end{tabular}

TABELA 4 - Base curricular - Barueri - 9oano - 2º trimestre de 2016

Conhecer os temas abordados nos direcionou para melhor elaboração de atividades, e propiciou a ligação entre nossas pesquisas e as aulas semanais. Essa relação forneceu a possibilidade de novas análises enquanto professor/pesquisador, também sendo suporte para pensamentos de planos de ação acerca dos conteúdos que trabalharemos, não somente como pesquisadores, mas também como professores.

Também decidimos analisar o material didático utilizado pelos alunos quanto à proposta de desenvolvimento de argumentação e prova matemática pelo estudante.

A prefeitura de Barueri trabalha com um sistema apostilado, mas que não são comprados de empresas privadas. As apostilas foram criadas e são atualizadas anualmente por professores que pertencem à rede Municipal.

A seguir, apresentamos uma análise do capítulo sobre equações polinomiais de $2^{\circ}$ grau da referida apostila. Foi escolhido um dos temas, sem motivo específico, apenas para entendermos o que o material oferece ao aluno do ponto de vista da argumentação e prova matemática.

O tema é abordado a partir da página 5 da apostila referente ao segundo trimestre. Há dois parágrafos iniciais de um texto de história da Matemática, em que os autores indicam alguns dos motivos para se desenvolver e resolver equações:

Há cerca de 2000 anos, as sociedades humanas já sabiam expressar sentenças matemáticas com o uso de variáveis. Mas, para tratar de problemas que 
envolvem, fundamentalmente, cálculo de áreas, os homens se viram frente a novos tipos de equações, nas quais a variável aparece elevada ao quadrado.

A presença de situações práticas que envolviam esse tipo de equação fez com que se desenvolvessem métodos cada vez mais rápidos para sua resolução. Um importante passo nesse sentido foi dado por Al-Khwarizmi, grande matemático árabe do século IX que, para tanto, utilizou um método geométrico: a formação de quadrados. (BARUERI, 2014, p. 5).

Segundo D’Ambrósio (2009), História da Matemática é uma ferramenta bastante importante para se trabalhar em sala de aula. Porém, o que há na apostila não oferece elementos que ajudarão o aluno a chegar em conclusões. Nesse caso, constatamos que a História da Matemática não foi utilizada para auxiliar o ensino da disciplina. Em seguida, há uma definição de equação de $2^{\circ}$ grau:

Denomina-se equação do 2o grau, toda equação do tipo:

$a x^{2}+b x+c=0$, onde $a$, $b$ e $c$ são números reais, com $a$ diferente de zero. Os números $a, b$ e $c$ são chamados de coeficientes da equação. (BARUERI, 2014, p. 5).

Não há qualquer tipo de atividade ou problema motivador. Apenas se apresenta a definição em uma linguagem matemática simbólico-algébrica e termos que podemos julgar “desconhecidos” pelos alunos. Adiante, há a definição do que é equação de $2^{\circ}$ grau incompleta, exemplos e exercícios para prática ou memorização. Notamos uma abordagem realizada apenas com o apoio da linguagem matemática, e absolutamente nenhuma situação-problema que desafie os estudantes. A abordagem pode não auxiliar os alunos no desenvolvimento da argumentação matemática.

Em seguida, a apostila contém exemplos de como identificar os coeficientes de uma equação de $2^{\circ}$ grau:

Exemplos:

\begin{tabular}{|c|c|c|c|c|}
\hline Equação do $2^{\circ}$ grau & Incógnita & $\boldsymbol{A}$ & $\boldsymbol{B}$ & $c$ \\
\hline $2 x^{2}+7 x+5=0$ & $x$ & 2 & 7 & 5 \\
\hline $3 y^{2}+y+2=0$ & $y$ & 3 & 1 & 2 \\
\hline
\end{tabular}




\begin{tabular}{|l|l|l|l|l|}
\hline $6 t-2 t^{2}+5=0$ & $t$ & -2 & 6 & 5 \\
\hline
\end{tabular}

Atenção!

Observe a terceira equação expressa na tabela. Primeiro precisamos organizar a ordem dos fatores (sic)

$$
a t^{2}+b t+c=0
$$

(BARUERI, 2014, p. 6).

$\mathrm{Na}$ página seguinte há um exercício em que o aluno tem que fazer o mesmo procedimento mostrado no exemplo:

2.Determine os valores de $a, b$ e $c$ nas seguintes equações:

\begin{tabular}{|l|l|l|l|}
\hline Equações & $\boldsymbol{a}$ & $\boldsymbol{b}$ & $\boldsymbol{C}$ \\
\hline$-15 x^{2}-3 x-5=0$ & & & \\
\hline$-5 y^{2}+20 y-7=0$ & & & \\
\hline $0,3-m^{2}=0$ & & & \\
\hline$\frac{x^{2}}{2}+\frac{1}{3} x+\frac{1}{6}=0$ & & & \\
\hline
\end{tabular}

(BARUERI, 2014, p. 7).

Notamos uma abordagem tradicional do tipo: definição e exemplo, seguido de exercício para "imitar" e aplicar o modelo. Além do conteúdo não ser abordado de forma que seja atrativa, o método de aula não fornece contribuição alguma para uso do raciocínio lógico dedutivo, e assim não propõe desenvolvimento de argumentação matemática.

Na maior parte da apostila, identificamos uma linguagem própria para quem já conhece o conteúdo. Na página 6 , apresenta-se uma “curiosidade" histórica, acreditamos, com o objetivo de deixar o conteúdo mais interessante:

$$
a x^{2}+b x+c=0
$$

O primeiro registro das equações polinomiais do $2^{\underline{o}}$ grau foi feito pelos babilônios. Eles tinham uma álgebra bem desenvolvida e resolviam equações 
de segundo grau por métodos semelhantes aos atuais ou pelo método de completar quadrados. Como as resoluções dos problemas eram interpretados geometricamente não fazia sentido falar em raízes negativas. O estudo de raízes negativas foi feito a partir do século XVIII. (BARUERI, 2014, p.6)

É relevante citar alguns termos que, muito provavelmente, os alunos não têm ideia do que significam, e certamente ficarão com as seguintes dúvidas:

1. O que são equações polinomiais?

2. Quais são os métodos atuais?

3. O que é o método de completar quadrado?

4. Como interpretar esses problemas geometricamente?

5. O que são raízes?

Todos esses conceitos poderiam ser adquiridos com o uso do raciocínio lógico dedutivo, com atividades que propiciem a argumentação matemática na resolução de equações, com ou sem o uso da interpretação geométrica, antes de apresentar um texto com informações que fazem sentido apenas para quem já conhece o tema.

Na página 8 , há um início de sistematização que trata da resolução de equações de $2^{\text {o }}$ grau incompletas:

Resolver uma equação significa determinar o conjunto solução que a torne verdadeira.

Para resolver uma equação incompleta do $2^{2}$ grau existem vários processos de resolução. Logo, para resolvê-las, temos que levar em conta o que a torne incompleta. Vamos analisar cada um dos casos separadamente.

1.Equações do tipo $a x^{2}=0$. Onde, $a \neq 0$ e $b=c=0$.

É só isolar o $x$. Veja:

$a x^{2}=0 \quad x^{2}=\frac{0}{a} \Rightarrow x^{2}=0 \Rightarrow x= \pm \sqrt{0}$

Todas as equações de segundo grau do tipo $a x^{2}=0$ têm solução $x=0 . \quad$ (BARUERI, 2014, p.8) 
É necessário fazermos uma reflexão sobre temas apresentados dessa forma. Ao definir, usar os termos dessa forma, resolver e generalizar a solução, o que sobra para o aluno pensar? A resposta que temos é: reproduzir em exercícios clássicos o que foi dito. Não há qualquer tipo de incentivo ao raciocínio ou à dedução, a busca por uma solução que faça sentido. O que há, na verdade, é uma série de símbolos que, se compararmos com os objetivos dos conteúdos de Matemática nos PCN, não fazem sentido algum da forma que foram apresentados. Essa mesma forma de apresentação do conteúdo continua sendo usada para outras equações incompletas:

2.Equação do tipo $a x^{2}+c=0$. Onde, $a \neq 0, b=0$ e $c \neq 0$.

Devemos novamente isolar o $x$.

$\frac{a x^{2}}{a}=\frac{-c}{a} \Rightarrow x^{2}=\frac{-c}{a}$

- Se $\frac{-c}{a}$ for negativo, não existe solução no conjunto dos números reais. A solução será, neste caso, vazia. $S=\{\}$.

- Se $\frac{-c}{a}$ for positivo, a equação terá duas raízes com o mesmo valor absoluto (módulo), mas de sinais contrários. Assim teremos $x= \pm \sqrt{\frac{-c}{a}}$. (BARUERI, 2014, p. 8).

Novamente, a apostila apresenta respostas diretas e uma linguagem completamente formal. Não há espaço para argumentação matemática e muito menos para qualquer uso do raciocínio lógico. O aluno não é convidado a elaborar conclusões a partir de relações que ele mesmo descubra, fazer qualquer tipo de conjectura, ou ainda, fazer tentativas para possíveis números que tornem a igualdade verdadeira. Não há espaço para que o aluno pense.

Em seguida, são apresentados exemplos resolvidos e exercícios. A impressão é de que o aluno precisa seguir a "receita" para resolução do problema. O modo tradicional do método de ensino dificulta o desenvolvimento da argumentação matemática por parte do aluno. Essa análise é de fundamental importância para que seja possível verificar o que está sendo "oferecido" ao aluno quanto auxílio ao desenvolvimento de argumentação matemática. Tanto a apostila quanto o livro deveriam ser facilitadores e incentivadores no processo de desenvolvimento da argumentação. O que, como vimos, na apostila não acontece.

Faremos, a seguir, uma breve análise do conteúdo do livro didático utilizado pela escola. 
O livro adotado pela escola foi fornecido pelo programa PNLD no último ciclo trienal, para começo de utilização no ano de 2014. O livro Matemática: Ideias e Desafios, para 9o ano, de Iracema Mori e Dulce Satiko Onaga, foi utilizado até o final do ano de 2016 como material de apoio.

No livro didático também há uma abordagem histórica inicial, mas esta é de forma mais rica, com detalhes e, sob nosso ponto de vista, com contos interessantes que envolvem equações de $2^{\underline{o}}$ grau. De início, as autoras apresentam o seguinte texto:

Imagine-se no topo de um edifício bem alto apreciando a paisagem à sua volta. De repente, dois objetos soltam-se de sua mão e caem no espaço...

Bem, não foi bem assim que aconteceu, mas conta-se que no início do século XVII, o físico, matemático e astrônomo italiano Galileo Galilei (15641642) soltou do alto da Torre Pisa, no mesmo instante, dois objetos de massas diferentes. Nesse experimento ele deduziu que, desprezando-se os efeitos da resistência do ar, os objetos chegariam ao solo ao mesmo tempo, por causa da ação da gravidade que a Terra exerce sobre os corpos.

Galileo Galilei expressou a lei da queda livre por meio da fórmula:

$$
s=\frac{1}{2} \cdot g \cdot t^{2}(\text { MORI E ONAGA, 2010, p. 64). }
$$

Fica a cargo do professor uma possível explicação das variáveis envolvidas na fórmula de $2^{\circ}$ grau apresentada. Em seguida, nenhuma articulação é feita com a História da Matemática, ou seja, o uso de história da matemática serviu como mero apontamento, ao invés de servir como fonte de inspiração ou de interesse para que o tema seja trabalhado. Na sequência, as autoras utilizam a fórmula do cálculo do número de diagonais de um polígono convexo:

O número de diagonais de um polígono convexo pode ser calculado pela seguinte fórmula:

$$
\begin{aligned}
& \boldsymbol{d}=\frac{\boldsymbol{n} \cdot(\boldsymbol{n}-3)}{2} \text { ou } \boldsymbol{d}=\frac{\boldsymbol{n}^{2}}{2}-\frac{3 n}{2} \\
& n=\text { número de lados } \\
& d=\text { número de diagonais }
\end{aligned}
$$

Nessa fórmula, atribuindo o valor de 9 a $\boldsymbol{d}$, temos a equação 
$\boldsymbol{n}^{2}-\mathbf{3 n}-\mathbf{1 8}=\mathbf{0}$, que é uma equação de $2^{\mathrm{o}}$ grau do tipo $\boldsymbol{a} \boldsymbol{x}^{2}+\boldsymbol{b x}+\boldsymbol{c}=\mathbf{0}$, com $a \neq 0$. (MORI E ONAGA, 2010, p. 65)

A fórmula para o cálculo do número de diagonais de um polígono também é apresentada de forma direta, sem demonstrações ou estímulos para que os alunos façam suas próprias conjecturas. É importante ressaltar que as autoras apresentam uma equação geral, mas em uma linguagem que só entenderá quem já estudou o tema, e com isso, a explicação fica totalmente a cargo do professor. De início é possível notar que não se dá a importância devida para argumentação matemática na apresentação do conteúdo, pois todas as conclusões necessárias sobre o que é uma equação do $2^{\underline{o}}$ grau, ou ainda quais são as suas aplicações, são apresentadas como se o aluno já conhecesse o tema.

Por meio da equação $x^{2}+10 x=39$, as autoras apresentam o método de completar quadrados. Novamente não se fornece espaço para o raciocínio lógico dos alunos, e não é necessário que cheguem a conclusão alguma, pois todas as conclusões são, outra vez, apresentadas de forma direta.

Sobre as resoluções de equações de $2^{\underline{0}}$ grau, primeiramente são abordadas equações incompletas do tipo $a x^{2}+b x=0$, com a seguinte questão:

O produto de um número inteiro pelo seu consecutivo é dez vezes o número menor.

Quais são esses números?

Nessa situação, equacionando o problema, obtemos uma equação de $2^{\underline{o}}$ grau com uma incógnita. Observe:

$\boldsymbol{x}=$ número menor; $\boldsymbol{x}$ é um número inteiro.

$\boldsymbol{x}+\mathbf{1}=$ consecutivo de $x$ (MORI E ONAGA, 2010, p. 70)

Na sequência, apresenta-se a equação de $2^{\circ}$ grau $x \cdot(x+1)=10 x$, obtida através do pensamento citado acima, e a sua resolução:

Escrevemos a equação obtida na forma reduzida:

$x \cdot(x+1)=10 x$ 


$$
\begin{aligned}
& x^{2}+x=10 x \\
& x^{2}+x-10 x=0 \\
& x^{2}-9 x=0
\end{aligned}
$$

Resolvemos essa equação fatorando $\boldsymbol{x}^{2}-\mathbf{9 x}$, e obtendo um produto de dois fatores iguais a zero:

$x^{2}-9 x=0 \Rightarrow x \cdot(x-9)=0$

Como o produto é zero, um dos fatores deve ser igual a zero:

$$
\begin{array}{ll}
x \cdot(x-9)=0 \quad & \Rightarrow \quad x=0 \\
& \text { ou } \\
& x-9=0 \quad \Rightarrow \quad x=9
\end{array}
$$

(MORI E ONAGA, 2010, p. 71)

Note que, pela primeira vez em todo o texto, foi feita uma argumentação: "Como o produto é zero então um dos fatores deve ser igual a zero", para se justificar uma passagem essencial à solução do problema.

Em seguida, as raízes são testadas para analisar a veracidade da igualdade, e a partir de $x$, encontra-se $x+1$ como resposta para o enunciado.

Podemos reparar que em nenhum momento o aluno precisa pensar em como resolver as equações, encontrar os resultados, ou até mesmo encontrar a equação para o problema proposto. Termos como "fatorar" e conclusões do tipo "como o produto é zero, um dos fatores deve ser igual a zero" são claros para pessoas que já sabem o conteúdo. Nesse ponto é necessário que deixe o aluno pensar nas possibilidades, que argumente sobre as suas conclusões.

Em outro ponto, é apresentado um problema do mesmo nível e estilo:

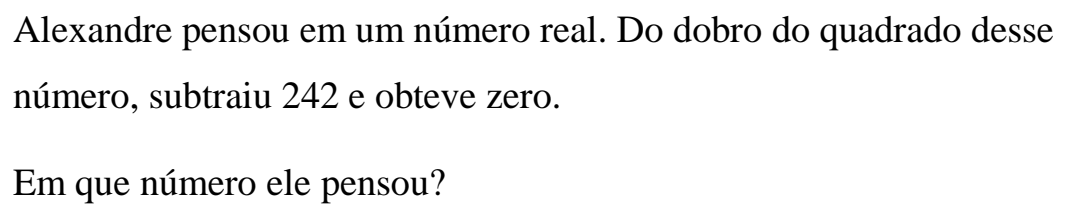

(MORI E ONAGA, 2010, p.71)

É importante analisar sobre como o tema é abordado, qual aplicação é utilizada, qual é o interesse que o aluno terá. Basta uma breve leitura para verificar que as aplicações e uso 
histórico de equações de $2^{\mathrm{o}}$ grau ficaram restritas à introdução ao conteúdo. O modo como o problema é resolvido segue o exemplo apresentado anteriormente.

Apesar de, ao representarmos a situação em equação de $2^{\circ}$ grau, obtermos uma equação incompleta com características diferentes da primeira para encontrar $2 x^{2}-242=0$, o livro sugere uma "receita", tanto para encontrar a equação, quanto para resolvê-la, exatamente como foi feito no primeiro problema. Como já dito, isso faz com que a solução seja obtida sem que o aluno seja convidado a participar de descobertas e, consequentemente, sem que possa desenvolver o nível de argumentação, de raciocínio lógico dedutivo ou indutivo, privando o aluno da oportunidade de pensar.

\subsection{A importância da formação do professor}

Segundo Sowder e Harel (1998), para que o educando desenvolva a capacidade/habilidade de argumentação e prova, é de fundamental importância que os docentes, parte essencial na formação do aluno, reconheçam e aceitem os vários níveis de argumentação e justificação apresentados pelos estudantes. Sobre a formação do professor de Matemática quanto ao conhecimento dos tipos de prova, estudamos também as obras de Boavida (2005), Hanna (1990), Junior (2012) e Pietropaolo (2005), onde os autores indicam que em trabalhos sobre o desenvolvimento de provas na Educação Básica, o pesquisador deve levar em consideração a formação acadêmica do professor e analisar possíveis influências das práticas docentes em fracassos ou sucessos no ensino-aprendizagem do aluno em relação ao tema proposto. Esses trabalhos serviram para que, durante a elaboração da uma proposta de ensino, estivéssemos atentos para evitar possíveis atuações equivocadas que pudessem prejudicar o processo de aprendizagem.

Ao longo de nossa pesquisa bibliográfica, encontramos trabalhos riquíssimos quanto à problemática do conhecimento do professor bom base nos diversos tipos de provas que podem ser desenvolvidas pelo estudante. Citaremos alguns pontos centrais em nossa discussão sobre a formação e participação do professor em relação à prática que propicie o desenvolvimento da habilidade de argumentação e prova matemática dos alunos na Educação Básica.

Primeiramente, citamos Boa Vida (2005) que realizou um estudo de investigação com duas professoras em seus trabalhos em sala de aula, orientado para o envolvimento dos alunos em atividades de argumentação matemática. A pesquisa de Boa Vida parte da análise de planejamento de atividades para duas turmas de $8^{\circ}$ anos de escolas situadas em Lisboa, 
Portugal. A ideia central era a de compreender o desenvolvimento das potencialidades dos alunos sobre o tema e entender os problemas do desenvolvimento de projetos de investigação sob a visão das práticas das professoras em relação a argumentação e prova matemática.

Após os acompanhamentos das atividades e aulas desenvolvidas pelas professoras, Boa vida (2005) conclui que episódios de argumentação são dependentes da quantidade de interação durante as aulas, ou seja, quando a ação do professor é realizada para encontrar formas de facilitar o desenvolvimento das habilidades de argumentar e provar de seus alunos. O professor, além de dominar os conteúdos matemáticos, deve ter bom conhecimento do currículo e de conexões entre os temas matemáticos nele incluídos, um interesse em gerar interações entre alunos e em atividades de formulação de conjecturas, além de avaliação coerente com o que foi proposto. Nesse contexto, a seleção de tarefas é fundamental para uma preparação cuidada e meticulosa das aulas, podendo gerar recursos que lhe permitem utilizar o melhor modo de agir para favorecer e apoiar a elaboração de argumentações e provas matemáticas por parte do estudante.

Boa Vida divide a sua análise das práticas das professoras em partes, sendo que, segunda a autora:

(...) A primeira, é dedicada à preparação de aulas orientadas para o envolvimento dos alunos em atividades de argumentação matemática. $\mathrm{Na}$ segunda e terceira, foco-me na argumentação matemática em ação, ou seja, começo por abordar vertentes do trabalho desenvolvido pelas professoras para facilitar nas aulas a formulação, avaliação e prova de conjecturas e, em seguida, centro-me em aspectos que mais diretamente se prendem com a criação de condições para surgir e se desenvolver um discurso argumentativo cujos padrões de avaliação são os do campo da Matemática adaptados à maturidade matemática dos alunos. Por último, refiro os principais desafios com que as professoras se confrontaram, a sua origem e principal incidência, bem como os que se destacam pela sua persistência. (BOA VIDA, 2005, p. 892)

As observações realizadas durante as aulas, planos de aulas, seleção de atividades e discussão sobre o tema (a autora denomina os momentos de discussão entre ela e as duas professoras de grupos de estudos), foram fundamentais para evidenciar a existência de seis espaços-problema que se inter-relacionam: 
(1) ensinar o valor das conjecturas e provas em Matemática e promover e sustentar a produção de provas;

(2) compreender as ideias apresentadas, instituí-las como recursos de apoio ao ensino e lidar com sentimentos que originam;

(3) descentrar o discurso de si, transformar a aula numa comunidade que cuida e combater a irresponsabilidade matemática dos alunos;

(4) apoiar a atividade dos alunos e favorecer a sua autonomia;

(5) harmonizar e equilibrar diferentes vozes na orquestração de discussões;

(6) articular propósitos e agendas pessoais com vontades dos alunos.

(BOA VIDA, 2005, p. 919)

Com base nas constatações, a autora afirma que as ações dos professores devem ser pensadas para superar as dificuldades citadas acima.

Boa Vida (2005) conclui que a boa prática docente é peça fundamental para bons resultados no que se refere ao desenvolvimento da habilidade de argumentação e prova dos alunos, reforçando a necessidade de que o professor deve saber o conteúdo matemático, entender o contexto didático para as aulas envolvendo o tema, além de práticas voltadas para argumentação matemática em sala de aula, entre outras habilidades.

Outro trabalho que nos ajudou é o projeto AProvaME, da PUC-SP (Pontifícia Universidade Católica de São Paulo). Neste projeto participaram 6 professores, 1 doutorando e 31 mestrandos do Programa de Estudos Pós-Graduados em Educação Matemática da PUC/SP, sendo produzidos diversos artigos sobre argumentação e prova na Educação Básica. Os objetivos do projeto eram:

1.Levantar um mapa das concepções sobre argumentação e prova de alunos adolescentes em escolas do estado da São Paulo.

2.Formar grupos colaborativos compostos por pesquisadores e professores para a elaboração de situações de aprendizagem, visando envolver alunos em processos de construção de conjecturas e provas em contextos integrando ambientes informatizados.

3.Criar um espaço virtual de compartilhamento entre os membros da equipe do projeto e analisar seu papel no desenvolvimento das situações de 
aprendizagem, assim como na evolução de conhecimentos pedagógicos sobre prova em Matemática.

4.Avaliar situações de aprendizagem, em termos da compreensão dos alunos sobre a natureza e funções de prova em Matemática.

5.Investigar a implementação destas atividades por diferentes professores e assim identificar em que medida sua participação nos grupos colaborativos fornece uma apropriação desta abordagem para o ensino e aprendizagem de prova.

6.Formular recomendações relacionadas ao papel da argumentação e da prova no currículo de Matemática escolar.

7.Contribuir para o debate internacional sobre o ensino e aprendizagem de prova em Matemática. (Disponível em http://www.pucsp.br. Acesso realizado em 27/01/2017)

Chamamos a atenção para dois pontos que observamos ao confrontarmos os trabalhos desenvolvidos:

- a diversidade de temas envolvendo a argumentação e prova no ensino básico;

- o direcionamento distinto das pesquisas, porém sempre enfatizando a importância da formação do professor de Matemática.

$\mathrm{Na}$ leitura das dissertações e artigos, notamos tanto a abordagem para ensino de conteúdos de Matemática como, por exemplo, Filho (2007) cujo a dissertação de mestrado tem o título desenvolvimento de uma sequência didática sobre quadriláteros e suas propriedades: contribuições de um grupo colaborativo, quanto a abordagem de temas voltados efetivamente para a formação do professor, como por exemplo no caso da dissertação de Grinkraut (2009) cujo título é Formação de professores envolvendo a Prova Matemática: Um olhar sobre o Desenvolvimento Profissional.

Especificamente sobre processos de formação de professores para o ensino de argumentação e prova, Grinkraut (2009) observou a prática de dois professores de Matemática do Ensino Médio da rede estadual de São Paulo. Os professores observados também faziam parte do projeto AProvaME como pesquisadores e eram alunos do programa de Mestrado Profissional em Ensino de Matemática pela PUC-SP. Grinkraut acompanhou-os no decorrer de dois anos, em que os professores elaboraram, aplicaram e analisaram situações de 
aprendizagem em Geometria, com o objetivo de que seus alunos construíssem argumentos e provas referentes ao tema. Segundo o autor, os estudos e a participação dos professores no projeto, proporcionaram discussões importantíssimas para promover transformações em concepções e práticas.

Grinkraut (2009) relata que enquanto o professor que efetivamente participou das discussões, a prática reflexiva, colaborativa e investigativa foi de fundamental importância para mudanças de concepções e práticas que propiciem o ensino de argumentação e prova, o outro, participando menos das discussões e das formações, não conseguiu romper com concepções e práticas anteriores, obtendo resultados menos significativos.

A conclusão de Grinkraut (2009) é de que a partir do momento em que os professores de Matemática passaram a valorizar as produções dos alunos e o raciocínio desenvolvido na elaboração da prova, sendo ela prática ou formal, muda-se a concepção e práticas do ensino de conteúdos com o ponto de vista de desenvolvimento de provas. $\mathrm{O}$ autor finaliza o seu trabalho indicando que há indícios de que os programas de formação de professores, pautados nas práticas de reflexão, colaboração e investigação, podem ser excelentes oportunidades de desenvolvimento profissional para os professores de Matemática envolvidos.

Pietropaolo (2005), em sua tese de doutorado, realizou uma pesquisa sobre o tema do ponto de vista do currículo e da formação dos professores. Intitulado: (Re) significar a demonstração no currículo da educação básica e da formação de professores de matemática, o trabalho teve como objetivo compreender a necessidade da implementação e analisar quão acessível isso é, além de investigar as implicações que provas e demonstrações como componentes do currículo trazem para a formação inicial dos professores.

Para chegar em seus objetivos, Pietropaolo (2005) realizou uma pesquisa bibliográfica vasta, com diversos estudos sobre práticas que propiciam o desenvolvimento de provas e demonstrações, currículo e formação de professores. Como parte da pesquisa, o autor levou em consideração várias entrevistas com professores de Matemática que lecionavam na Educação Básica e que tinham, em alguma parte de seu trabalho, a experiência com atividades envolvendo desenvolvimento de provas de estudantes, além de entrevistas com pesquisadores em Educação Matemática.

Pietropaolo (2005) conclui que a prova matemática de um ponto de vista amplo, da mesma forma que defendemos durante o desenvolvimento deste trabalho, e não somente da maneira axiomática apresentada pela comunidade matemática, é um recurso pedagógico muito 
importante durante as aulas dos Ensinos Fundamental e Médio, reforçando que para obtermos sucesso, de fato, é necessário que nos atentemos para a formação inicial dos professores de Matemática, com o intuito de que esse sentido mais amplo de prova e demonstração seja levado em consideração pelos educadores. Pietropaolo afirma que:

Assim, nossa pesquisa mostra que as demonstrações nos cursos de formação de professores no ensino básico devem ter um enfoque bem mais amplo do que tem sido dado. Essa amplitude pode ser alcançada se os cursos não utilizarem as provas apensar para aprender mais Matemática ou com o objetivo de desenvolver o raciocínio matemático, mas também em sua perspectiva didática, curricular e histórica. Uma das possibilidades seria, por exemplo, refletir sobre a "evolução" do pensamento matemático, no qual se inclui a demonstração, indispensável à Matemática”. (PIETROPAOLO, 2005, p. 223)

Com as entrevistas e nas pesquisas com professores, Pietropaolo observou que quando o professor possui somente o conceito de prova matemática rigorosa, não aceita o pensamento do aluno como prova quando uma demonstração formal não é apresentada, já que não há rigor do ponto de vista da Matemática, colocando em risco o desenvolvimento do estudante. Como consequência o autor propõe novos significados para provas e demonstrações no currículo da Educação Básica, concluindo que o tema deve fazer parte da formação do estudante, desde que seja abordado por um processo de investigação, questionamentos, conjecturas, ou seja, de um modo mais amplo e não necessariamente rigoroso.

Por fim, o trabalho de Pietropaolo (2005) nos evidenciou o grande campo de discussão que temos, tanto para análise do currículo da Educação Básica, mas também para a necessidade da formação dos professores quanto aos conceitos de prova e demonstrações de estudantes.

Encontramos outros trabalhos recentes que investigaram a necessidade de mudanças na formação inicial dos professores de Matemática quanto a um conceito mais amplo de prova e demonstração na Matemática escolar. Em geral, os trabalhos são pautados em entrevistas com os professores de Matemática que já atuam na Educação Básica, e de que forma os professores avaliariam provas desenvolvidas por estudantes. Pesquisas como, por exemplo, as de Matheus (2016) e Almouloud (2008) corroboram com essas ideias.

Nossas leituras foram essenciais no processo de entendimento de que as mudanças das práticas da sala de aula estão estritamente relacionadas com a formação inicial dos professores. 
Entretanto, a discussão é ampla, e precisaríamos de outra dissertação para que realizássemos conclusões referentes à formação. Dessa forma, nos propondo a responder as perguntas que deram origem a esse trabalho, apresentamos no capítulo a seguir, as atividades envolvendo prova matemática no contexto escolar realizadas com os estudantes de $9^{\underline{0}}$ ano do Ensino Fundamental e as análises dos dados que obtivemos. 


\section{A Aplicação das atividades}

Com base em nossa metodologia, buscamos entender qual é o nível de argumentação que nossos alunos conseguem trabalhar.

Aplicamos uma primeira atividade diagnóstica para que pudéssemos, em seguida, estruturar o nível das questões que poderíamos propor durante a pesquisa.

Certamente os trabalhos de Sowder e Harel (1998), Nasser e Tinoco (2003), Rezende e Nasser (1994), Balacheff (1987), entre outros, nos deram a direção sobre práticas no ensino de argumentação e prova matemática. Ao pensarmos nas questões iniciais para aplicação com os alunos, certamente houve influência de nossas referências bibliográficas na elaboração de todos os exercícios, fazendo com que cada um deles tenha um objetivo específico, e de acordo com a metodologia de pesquisa adotada, que nos oriente a planejar sempre antes de agir. Porém, acreditamos ser relevante dizer que, mesmo sabendo das práticas que podem colaborar com a melhoria do nível de sua argumentação dos estudantes, nesse primeiro momento focamos em obter os resultados qualitativos dessa "atividade piloto", evitando que o comportamento do pesquisador/professor no decorrer da resolução dos problemas feita pelos alunos influenciasse na conclusão dessa primeira tarefa. Ora, sabemos que é coerente que algumas atividades sejam feitas em grupo, por exemplo, para que as afirmações sejam postas em confronto, mas na atividade diagnóstica, decidimos por bem não realizar tais práticas.

Finalmente, para que pudéssemos coletar informações sobre o nível dos alunos quanto à argumentação matemática, aplicamos a seguinte atividade: 


\section{Atividade 1 - diagnóstica}

\section{1) Considere a afirmação:}

Somando dois números ímpares, sempre obtemos um número par.

Diga se essa afirmação é falsa ou verdadeira, justificando.

2) Juan é jogador de um time da primeira divisão de seu país. Veja abaixo a quantidade de gols que Juan fez nos campeonatos nacionais dos últimos anos.

Ano
\begin{tabular}{|l|l|}
\hline 2015 & 14 \\
\hline 2014 & 17 \\
\hline 2013 & 20 \\
\hline 2012 & 23 \\
\hline 2011 & 26 \\
\hline
\end{tabular}

Analisando a Tabela, qual é a quantidade de gols que Juan vai fazer no campeonato de 2016 ?

\section{3) A professora de Rogério pediu que ele resolvesse a equação abaixo:}

$5 x^{2}+5 x-10=0$.

O aluno encontrou as soluções $x=1$ e $x=-2$.

O livro usado pela turma apresentava as respostas $x=1$ e $x=3$.

Sabendo que a questão vale 2 pontos, considerando as respostas, qual é a nota que você daria para Rogério?

Como dissemos, cada questão traz consigo um objetivo de verificação. Na questão 1, a ideia é diagnosticar se o estudante reconhece que a soma de dois números ímpares é sempre um número par. Porém, de acordo com nosso referencial teórico, há diversas maneiras/níveis que podem ser apresentadas as justificativas pelos alunos. Desde uma prova baseada em um simples exemplo, até um pensamento generalizado, levando em consideração uma soma algébrica que represente a propriedade mencionada acima de modo geral. Por exemplo, como resposta à questão número 1, o aluno A argumenta que: 


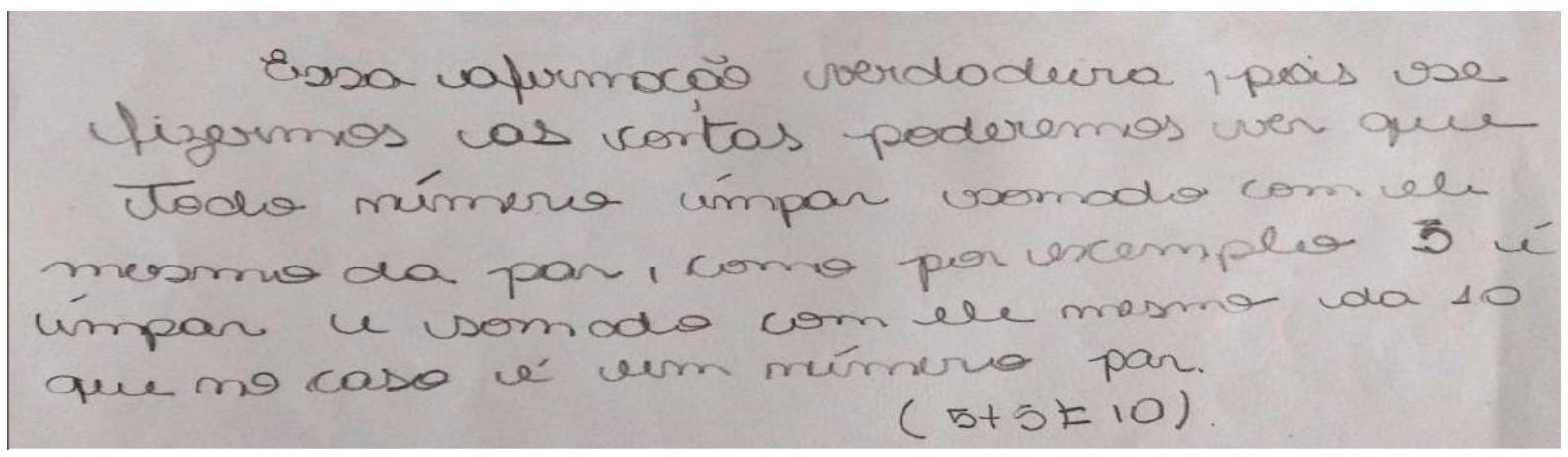

FIGURA 6 - Resposta do aluno A - Atividade 1 - diagnóstica - Questão 1

Analisando a resposta acima, claramente o aluno se baseia em apenas um exemplo $(5+5=10)$ e generaliza o resultado para a soma de quaisquer ímpares. Segundo Balacheff (1987), tal prova é considerada uma prova pragmática e é um exemplo de empirismo ingênuo, pois o estudante não percebe claramente o problema da generalização e conclui sobre a certeza de uma afirmação com base apenas em um exemplo. Já Sowder e Harel (1998), classificam que essa prova se encontra no esquema de prova empírico, mais precisamente no esquema de prova baseado em exemplos. Embora os trabalhos dos autores citados acima nos levem a várias possibilidades de mediação para esse tipo de prova, nos atentamos inicialmente somente para o resultado qualitativo da questão, para que possamos ter em vista qual é o nível intelectual dos estudantes quanto a habilidade de argumentação matemática, o que, segundo a nossa metodologia, é fundamental para os passos seguintes do trabalho.

Outras quatro respostas também nos chamaram muita a atenção nesse primeiro momento. $\mathrm{O}$ aluno B diz que:

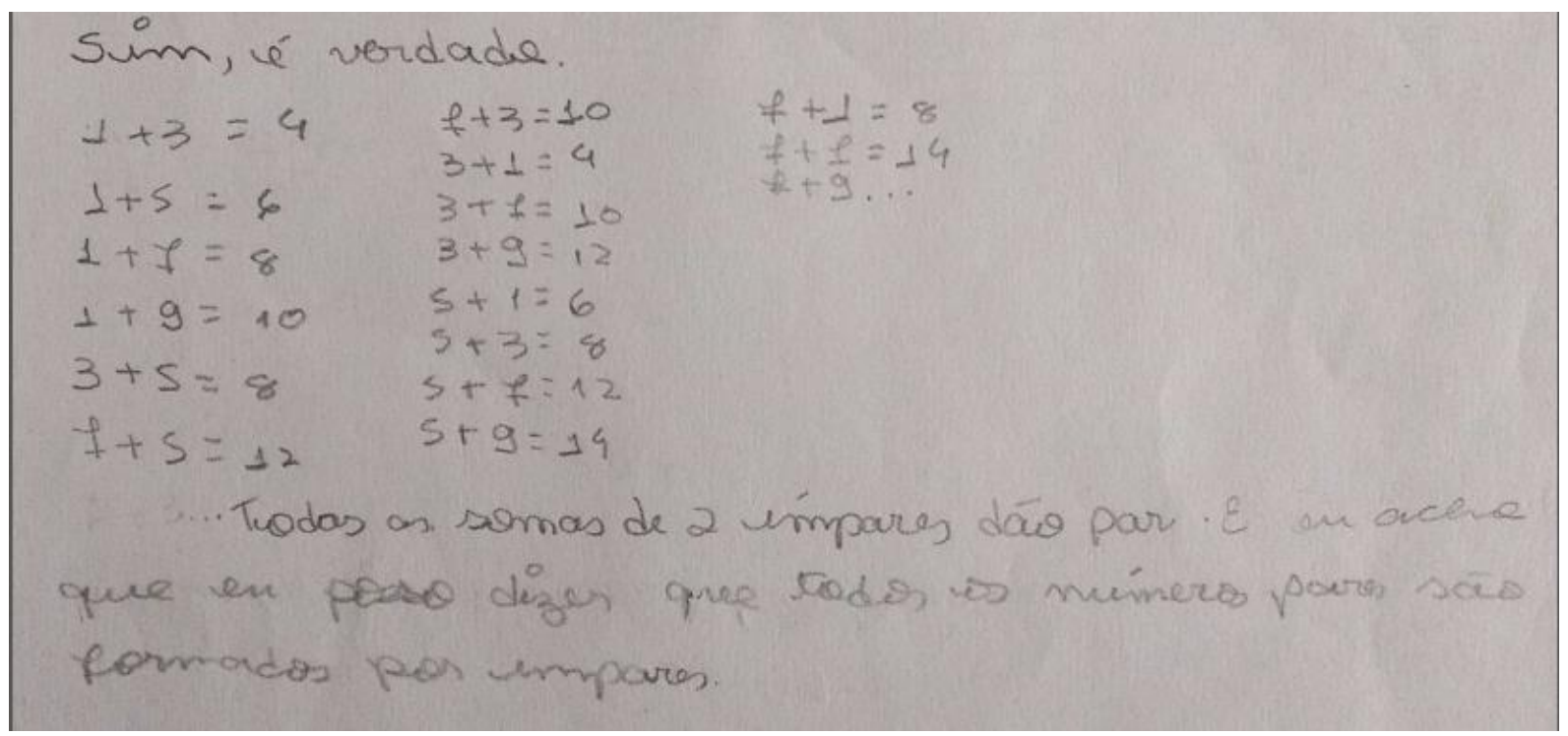

FIGURA 7 - Resposta do aluno B - Atividade 1 - diagnóstica - Questão 1 
Podemos notar que o estudante realiza uma série de testes para verificar se a afirmação é, de fato, verdadeira. Esse processo, segundo Balacheff (1987), caracteriza uma prova pragmática, mas diferentemente da prova da aluna anterior, os testes não param apenas com um exemplo. Ainda assim, temos mais um exemplo de empirismo ingênuo. Nos atentamos para o fato de que o aluno realizou um número maior de testes, claramente com o objetivo de se convencer ou convencer o leitor sobre a veracidade da afirmação. Também é interessante observar que ele evitou as somas $1+1,3+3,5+5$, mas calculou $7+7$.

Outra prova foi realizada pelo aluno $\mathrm{C}$ com os seguintes argumentos:

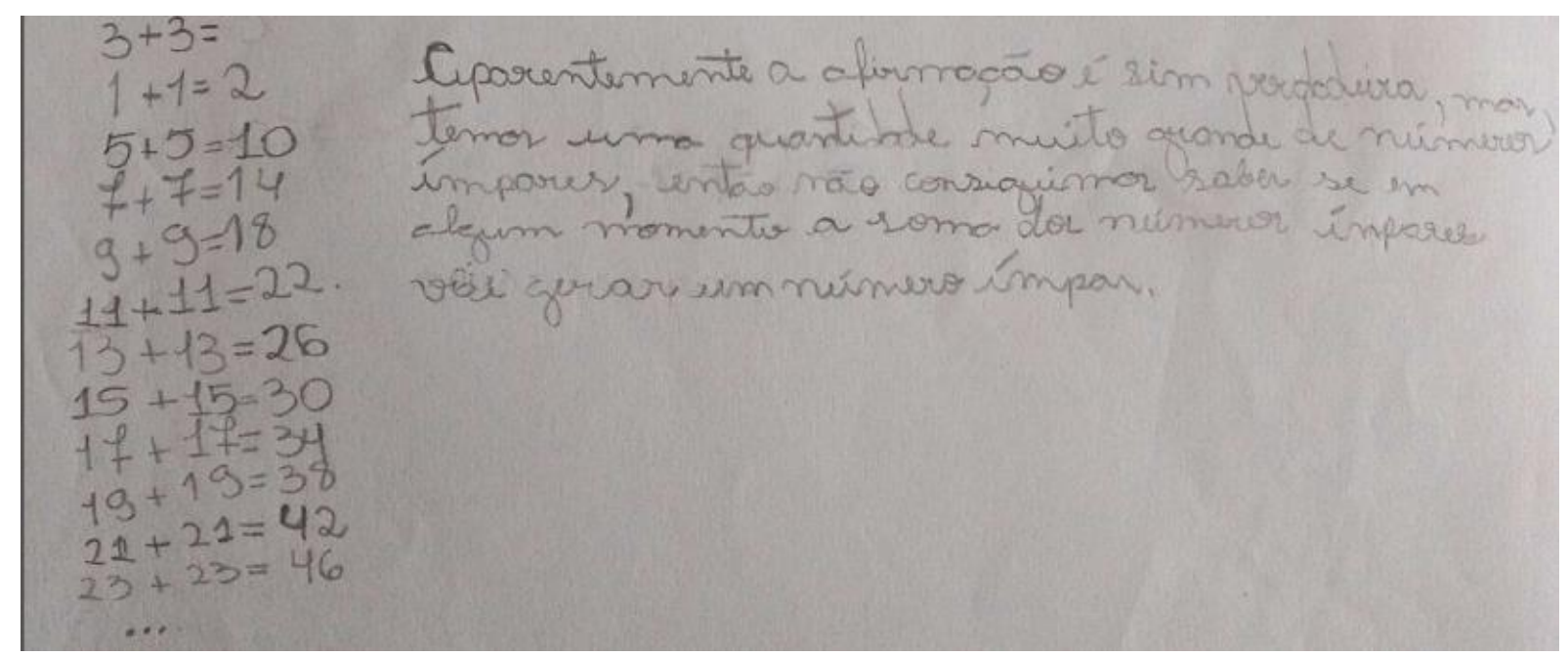

FIGURA 8 - Resposta do aluno C - Atividade 1 - diagnóstica - Questão 1

O tipo de prova realizado por esse aluno é muito parecido com a prova exposta pelo aluno B, por apresentar vários exemplos. Recordemos que para De Villiers (2001), o convencimento é uma das funções primordiais da prova, exatamente o que as estudantes objetivam ao realizar os testes. Porém, o que nos chama a atenção é a frase colocada ao lado do argumento numérico: “- Aparentemente a afirmação é sim verdadeira, mas temos uma quantidade muito grande de números ímpares, então não conseguimos saber se em algum momento a soma dos números ímpares vai gerar um número ímpar”. Temos um processo de avaliação delicado. Não há conclusão sobre a veracidade da afirmação. O que o aluno faz é utilizar o argumento para um convencimento próprio, mas ainda parcial. Ao analisarmos puramente o argumento numérico, segundo Balacheff (1987), poderíamos classificar como mais um empirismo ingênuo. Levando em consideração a tipologia de prova desenvolvida por Sowder e Harel, temos um caso compatível com o esquema de prova baseado em exemplos. E, ainda, de acordo com os tipos de provas apresentados por Rezende e Nasser (1994) temos um exemplo de prova pragmática. Entretanto a frase do estudante mostra que ele está consciente 
de que há um problema de generalização em questão. O aluno reconhece que deve tratar da situação de modo geral, apenas não apresentou um argumento necessário para concluir sobre a veracidade da afirmação. Consideramos, com base em Balacheff (1987), que os argumentos do aluno $\mathrm{C}$ podem ser classificados como empirismo ingênuo. Mas, claramente, esse aluno mostra estar consciente do problema da generalização, embora não tenha conseguido apresentar uma prova para o caso geral.

Analisamos outra prova em um primeiro momento, que também nos chamou bastante a atenção pela tentativa de generalização da questão apresentada:

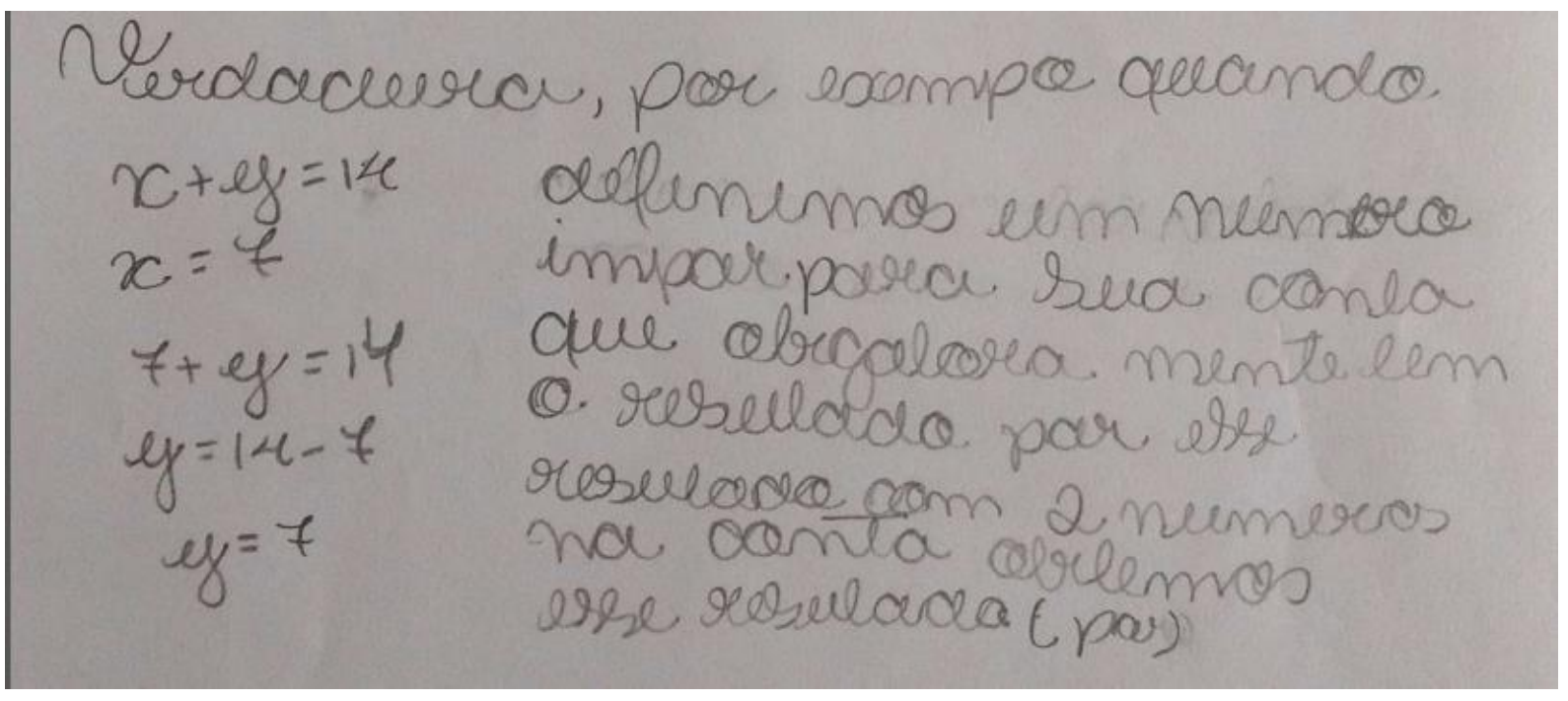

FIGURA 9 - Resposta do aluno D - Atividade 1 - diagnóstica - Questão 1

Notamos que o aluno D já está convencido da veracidade da afirmação, mas esbarra na ideia da generalização. O interessante é que o estudante acaba utilizando apenas um exemplo, mesmo que por uma equação. A ideia é, no mínimo, muito criativa e passa por um processo investigativo importante. O resultado 14 poderia variar, assim como o valor de $x$ atribuído poderia ser outro, e da mesma forma encontraríamos um valor ímpar para $y$. Analisando segundo Balacheff (1987), o que temos é um exemplo genérico, pois a expressão é um representante de toda a classe de objetos. Acreditamos que o estudante apresenta conhecimento essencial para que possa fazer a passagem para provas classificadas como experimentos mentais. O aluno esbarra no que Balacheff chama de: passagem de uma linguagem de familiaridade para uma linguagem funcional.

Por fim, chegamos à resposta do aluno $\mathrm{E}$, que certamente é a que mais se aproxima de uma prova formal. $\mathrm{O}$ aluno $\mathrm{E}$ diz que: 
$a=$ qualquer número ímpar.

$a+a=2 a$

Todo número multiplica do por 2, é par.

FIGURA 10 - Resposta do aluno E - Atividade 1- diagnóstica - Questão 1

Como pode ser observado, o aluno E restringe sua prova para números ímpares iguais. Nos apoiando em Balacheff (1987), podemos observar que o problema de generalização foi levantado. Consideramos o que o aluno elaborou uma prova parcial, pois é o que mais se aproxima de uma prova que consiste em um experimento mental. Estamos justamente na passagem de uma prova pragmática para uma prova intelectual. Ou para Sowder e Harel (1998), temos uma aproximação de uma prova contida no esquema de prova transformacional, ou seja, uma prova que repousa no esquema de prova analítico.

No total, a primeira atividade para diagnóstico da turma foi aplicada a 23 alunos. Além das observações sobre as provas apresentadas até aqui, há uma outra prática dos estudantes que também nos chamou atenção: todos os alunos que responderam o questionário utilizaram argumentos escritos em língua materna. Não estamos aqui dizendo que isso seja um problema no processo de aprendizagem de provas matemáticas, pelo contrário, segundo Machado (1993) Matemática e Língua Materna devem caminhar juntas desde o início do aprendizado dos alunos, pois há grande auxílio em ambas as áreas. Mas, as respostas nos fizeram refletir sobre o significado da palavra “justificar” para nossos estudantes. Tal reflexão certamente ajudou para as atividades aplicadas posteriormente. Como sequência fizemos a tabulação da primeira questão segundo a tipologia de prova desenvolvida por Balacheff (1987), e representamos na tabela a seguir:

\begin{tabular}{|l|l|}
\hline Tipo de prova & Número de alunos \\
\hline Empirismo ingênuo & 16 \\
\hline
\end{tabular}




\begin{tabular}{|l|c|}
\hline Experimento crucial & 1 \\
\hline Exemplo genérico & 1 \\
\hline Experimento Mental & 1 \\
\hline
\end{tabular}

TABELA 5. Tabulação - Atividade 1 - diagnóstica - Questão 1

Três alunos apenas escreveram que a afirmação é verdadeira, mas não justificaram numericamente ou de forma escrita. E, como já observado, tivemos a prova do aluno $\mathrm{C}$, que foi classificada como empirismo ingênuo, mas que tinha clareza de que aquele argumento era insuficiente.

A segunda questão que propusemos teve como objetivo diagnosticar se os alunos sabem analisar padrões e conseguem perceber se há ou não conclusões a serem feitas. A questão é:

2) Juan é jogador de um time da primeira divisão de seu país. Veja abaixo a quantidade de gols que Juan fez nos campeonatos nacionais dos últimos anos.

\begin{tabular}{|l|l|}
\multicolumn{1}{l}{ Ano } & Gols \\
\hline 2015 & 14 \\
\hline 2014 & 17 \\
\hline 2013 & 20 \\
\hline 2012 & 23 \\
\hline 2011 & 26 \\
\hline
\end{tabular}

Analisando a Tabela, qual é a quantidade de gols que Juan vai fazer no campeonato de 2016 ?

A ideia é que o aluno observe a progressão aritmética decrescente de razão três, que representa os gols realizados pelo jogador no decorrer dos anos. Entretanto não há nada que garanta que esse jogador fará 11 gols no ano de 2016. A resposta esperada é justamente a conclusão de que não há motivos que garantam que o padrão necessariamente seja respeitado para os anos seguintes.

O número de respostas que seguiram a ideia de que o jogador fará 11 gols foi surpreendente. E mesmo quando não responderam 11, todos os alunos argumentaram com base em um número fixo de gols. A única resposta com uma observação da validade do padrão para os anos seguintes foi a apresentada pelo aluno F, destacada abaixo: 


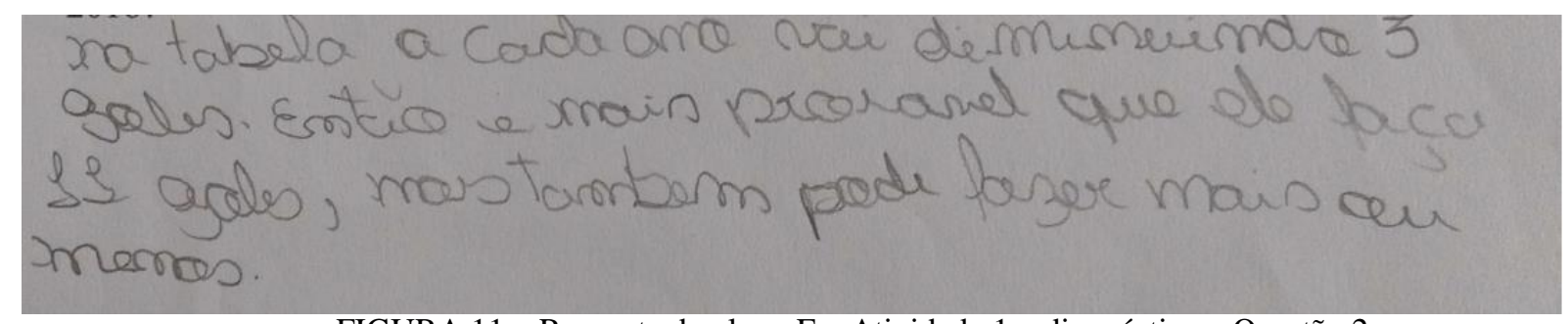

FIGURA 11 - Resposta do aluno F - Atividade 1 - diagnóstica - Questão 2

Mesmo admitindo que "é mais provável” que o padrão seja seguido, há um questionamento da validade da progressão aritmética para a situação.

Essa questão foi importante para as atividades seguintes, pois sabemos como os alunos analisam padrões e acreditam em suas validades, mesmo em situações em que não há possibilidade de prova matemática.

Tabulando sobre as respostas para a questão, notamos que:

\begin{tabular}{|l|l|}
\hline Conclusão & Número de alunos \\
\hline Juan fará 11 gols & 18 \\
\hline Outro valor & 5 \\
\hline
\end{tabular}

TABELA 6. Tabulação - Atividade 1- diagnóstica - Questão 2

Há certamente um problema gerado a partir dos erros de interpretação e dificuldade em conteúdos matemáticos específicos, que é o de não conseguirmos analisar o nível de prova, pois simplesmente não há argumento correto exposto pelo aluno. Tal questão nos mostrou que o conteúdo matemático deve ser levado em consideração em nossas elaborações de futuras atividades.

Sobre a última questão da atividade diagnóstica, o objetivo era o de nos fornecer a resposta de qual é a visão dos alunos sobre as informações apresentadas por um professor, por um livro didático, ou até por outro aluno que é reconhecido por ter facilidade em Matemática.

Aplicamos a atividade após os alunos terem estudado equação de $2^{\circ}$ grau por quase dois meses. O ideal era que os alunos soubessem os caminhos de encontrar as raízes reais, caso possível, da equação dada. Tivemos respostas de várias formas, como por exemplo a afirmação do aluno A, que diz: 


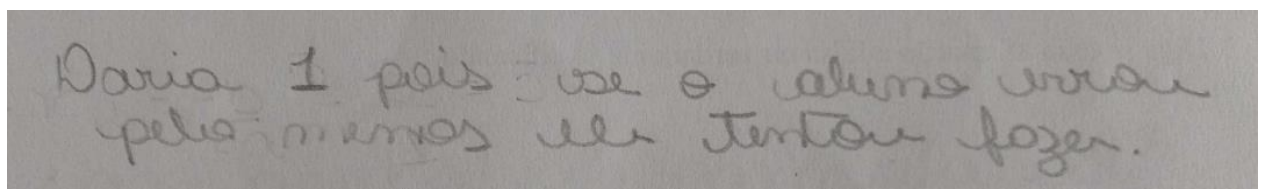

FIGURA 12 - Resposta do aluno A - Atividade 1- diagnóstica - Questão 3

A argumentação nos mostra que há uma crença no que o livro afirma, mesmo sem procurar saber da veracidade da afirmação, sem realizar testes. Não há argumentação matemática. Segundo Rezende e Nasser (1994) temos aqui a recorrência a uma autoridade. Mesmo que não estejamos falando de uma prova elaborada, a ideia era justamente refutar a afirmação errada fornecida por um professor ou livro, o que notadamente não acontece. A credibilidade que o aluno tem no professor ou livro, pode ser prejudicial, se não for acompanhada com argumentos. Segundo Sowder e Harel (1998) os professores devem desenvolver atividades que proponham questionamentos sobre a veracidade de uma afirmação apresentada por uma autoridade no assunto.

O aluno B não apenas resolveu a equação, como também substituiu os valores dados pelo livro para poder concluir que o livro apresentava uma resposta incorreta.

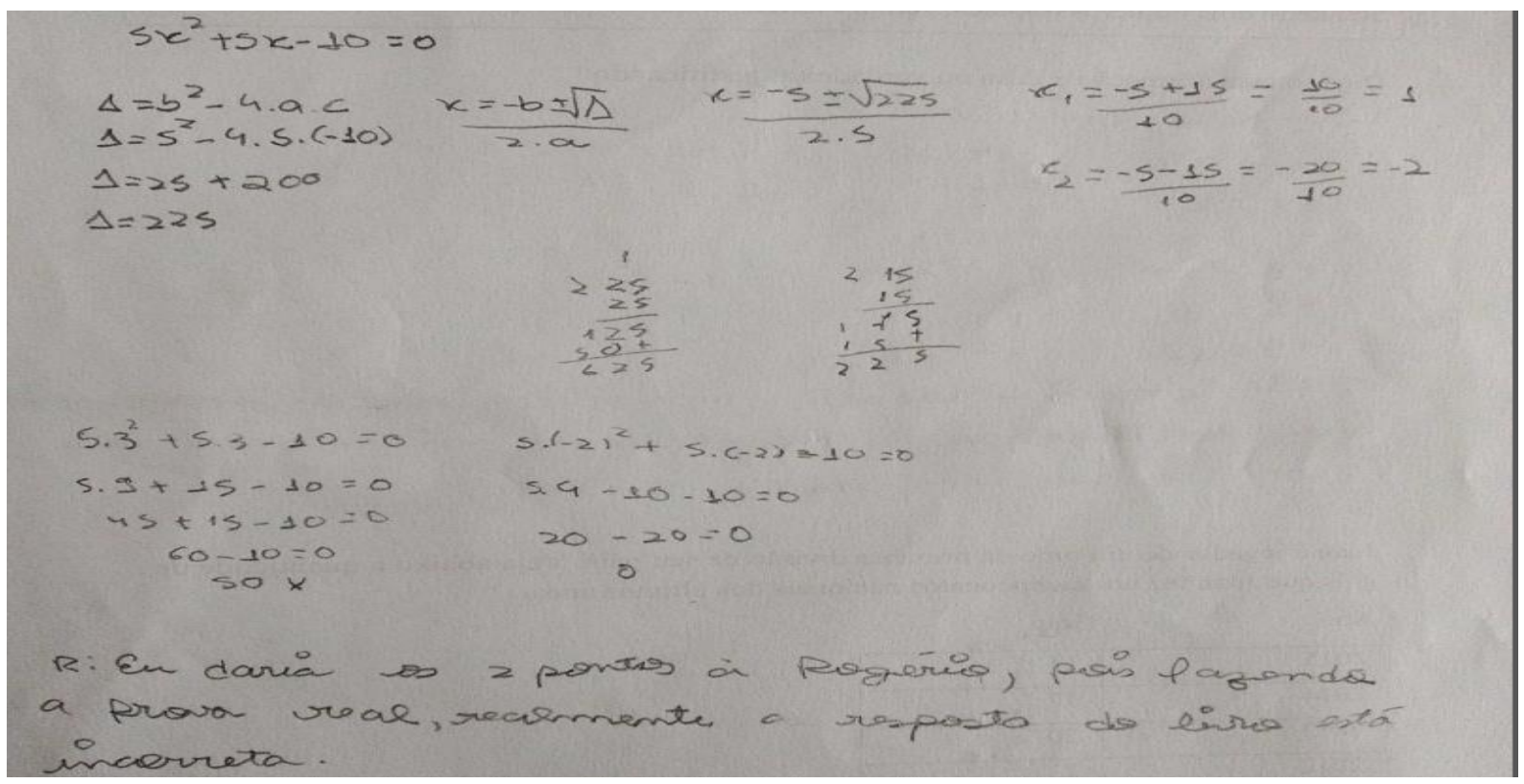

FIGURA 13 - Resposta do aluno B - Atividade 1 - diagnóstica - Questão 3

Os alunos que não usaram o que foi chamado de recorrência a uma autoridade, segundo Rezende e Nasser (1994), ou esquema de prova autoritário, segundo Sowder e Harel (1998) apresentaram argumentos mais ricos, obtidos por meio de raciocínio articulado e convincente. 
Podemos visualizar, na tabela a seguir, qual é o perfil da turma quanto aos argumentos realizados com base somente em crenças de afirmações vindas de autoridades no assunto:

\begin{tabular}{|l|c|}
\hline Tipo de argumento apresentado & $\mathrm{N}^{\circ}$ de alunos \\
\hline Argumento com base somente na afirmação da autoridade & 10 \\
\hline Argumentação por meio de cálculo correto das raízes. & 6 \\
\hline Argumentação por meio de cálculo incorreto das raízes. & 5 \\
\hline
\end{tabular}

TABELA 7. Tabulação - Atividade 1- diagnóstica - Questão 3

A tabela evidencia dois problemas:

- Quase $50 \%$ das provas realizadas pelos estudantes que participaram desta pesquisa foram baseadas em afirmações de professores ou livros de Matemática sem que os alunos tivessem verificado, questionado ou testado.

- Quase $25 \%$ dos alunos mostrou dificuldade com o conteúdo matemático, o que, é claro, compromete possíveis argumentações e provas.

As atividades nos foram úteis para que pudéssemos traçar o perfil da sala, o que, segundo Coob et al (2003), é fundamental para definir a forma como irá continuar uma pesquisa como a nossa.

\section{Discussão com os alunos}

Antes de darmos sequência em nossas atividades, decidimos discutir cada uma das questões presentes no questionário 1. O objetivo era que os estudantes analisassem pontos importantes de cada tarefa.

\section{Questão 1}

Segundo Sowder e Harel (1998), o professor deve propor atividades que quebram a ideia de que alguns exemplos bastam para afirmar sobre a veracidade de algo. Como início da atividade, fizemos a seguinte pergunta:

- Será que dois ou três exemplos são suficientes para concluir? 
Alguns alunos disseram que sim, e então lemos a resposta da aluna B, sem identificação. Os estudantes, em geral, concordaram com a ideia, mas ainda assim alguns diziam que os testes eram suficientes. Fizemos em seguida a análise de uma situação já vivenciada em sala de aula. Em uma das tentativas de encontrar a solução simplificada por meio das raízes para uma equação do tipo $a x^{2}+b x+c=0$, dissemos que poderíamos resolver as equações apenas considerando que:

Sendo $x_{1} e x_{2}$ as raízes da equação. Então a soma dessas raízes é: $x_{1}+x_{2}=-b$ e o produto das raízes é: $x_{1} \cdot x_{2}=c$

Pedimos que verificassem se a afirmação é correta por meio das equações:

$$
\begin{aligned}
& x^{2}-4 x+3=0 \\
& x^{2}+2 x-8=0 \\
& x^{2}-2 x-80=0
\end{aligned}
$$

Logo após a validação, os estudantes tinham convencimento de que a solução era válida para todas as equações, chegando ao ponto de alguns alunos reclamarem por termos descoberto, anteriormente, uma fórmula "tão grande" para resolução.

Como sequência, pedimos que os estudantes testassem a nova forma de resolver para a equação: $3 x^{2}+4 x+1=0$, o que, claro, não deu certo.

Fortalecemos que as verificações para as cinco equações não foram suficientes para que soubéssemos da resolução para uma equação geral por meio da soma e produto de suas raízes.

Por fim, apresentamos a relação correta entre a soma e o produto das raízes de uma equação de $2^{\mathrm{o}}$ grau, propositadamente sem demonstração ou qualquer justificativa, com o objetivo de que os alunos questionassem, em algum momento das aulas, sobre a veracidade da afirmação. O problema foi que novamente a recorrência a autoridade fez com que os estudantes não questionassem os argumentos que nos levaram a conclusão. Como estratégia, abordamos o mesmo tema na atividade 3, que será apresentada neste trabalho.

\section{Questão 2}

Sobre a segunda questão, fizemos a seguinte pergunta aos alunos:

- E se o atacante jogar o melhor campeonato de sua vida? 
O objetivo era que a questão faça com que o aluno repense sobre possíveis padrões sem considerar se as premissas são sempre válidas. No início, os alunos apresentaram argumentos com base na sequência numérica ordenada encontrada, porém, bastou poucos momentos para falas do tipo "não é certeza" ou ainda, "ele pode fazer mais ou menos gols".

\section{Questão 3}

Começamos a discussão da terceira questão com a frase:

- As raízes da equação $5 x^{2}+5 x-10=0$ são $x=1$ e $x=3$.

Levando em consideração as ações propostas por Sowder e Harel (1998) e Rezende e Nasser (1994), a questão 3 é voltada para observação de possíveis erros de fontes confiáveis segundo os estudantes, e fazer com que argumentações baseadas unicamente em autoridades sejam repensadas

Após alguns minutos em que defendemos a resposta do livro, fizemos as perguntas:

- Professor erra?

- Autores de livro erram?

- Digitadores erram?

A ideia era incentivar a discussão entre os estudantes, o que certamente levaria, e de fato levou, alguns alunos a argumentarem que as raízes corretas são diferentes das apresentadas na questão. A evidência disso é o desenvolvimento da resolução da equação apresentados por alguns estudantes.

Após a discussão, os alunos pediram insistentemente para refazerem as questões, pois agora estavam com ideias para escreverem. Considerando que os estudantes refletiram sobre pontos importantes na questão da generalização e argumentação matemática, acreditamos que dar a oportunidade de discussão aos estudantes seria um incentivo ao desenvolvimento do nível de argumentação desses alunos. O objetivo era verificar possíveis evoluções sobre a necessidade de provar, um dos requisitos mais importantes defendidos por Balacheff (1987).

$\mathrm{Na}$ análise dos dados, encontramos algumas diferenças cruciais quanto à argumentação matemática de alguns alunos. Acreditamos que ao visualizar a palavra justifique, muitos alunos buscam auxílio da língua materna para expressar a sua ideia. Novamente, deixamos claro que isso não é de todo ruim. Porém, uma suposta obrigatoriedade de escrever um texto em uma 
linguagem não matemática nos parece tirar o incentivo da utilização da linguagem matemática para validação de uma informação. Defendemos aqui a utilização da língua materna para argumentação, mas não a obrigatoriedade de usá-la.

Por exemplo, os alunos que argumentaram com a frase "todos os números ímpares", poderiam argumentar com uma linguagem matemática usando a frase: o número $2 k+1$, para todo $K \in \mathbb{Z}$.

Analisando as respostas obtidas no questionário 2, pudemos notar que alguns estudantes que produziram provas consideras, segundo Balacheff (1987), como empirismo ingênuo, passaram a argumentar percebendo que o pequeno número de exemplos não seria suficiente para a conclusão sobre a veracidade da afirmação.

Voltando a questão:

\section{1) Considere a afirmação:}

Somando dois números ímpares, sempre obtemos um número par.

Diga se essa afirmação é falsa ou verdadeira, justificando.

O aluno G diz:

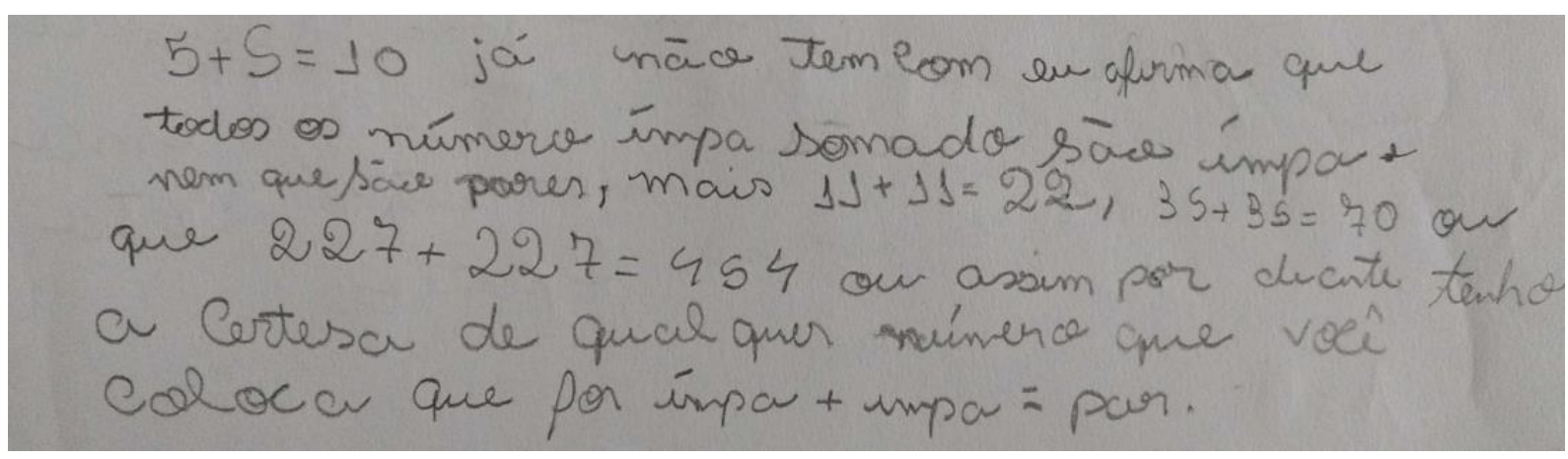

FIGURA 14 - Resposta do aluno G - Atividade 1 - reaplicação - Questão 1

Apesar de o argumento ainda se basear em exemplos, há mudança no processo da prova. $\mathrm{O}$ aluno $\mathrm{G}$ faz experimentos tão livres quanto possíveis, e após os testes há a conclusão embasada em seus resultados. Esse tipo de prova é caracterizada por Balacheff como experimento crucial.

Outra resposta que nos chamou atenção é um argumento do aluno F, todo realizado na língua materna: 


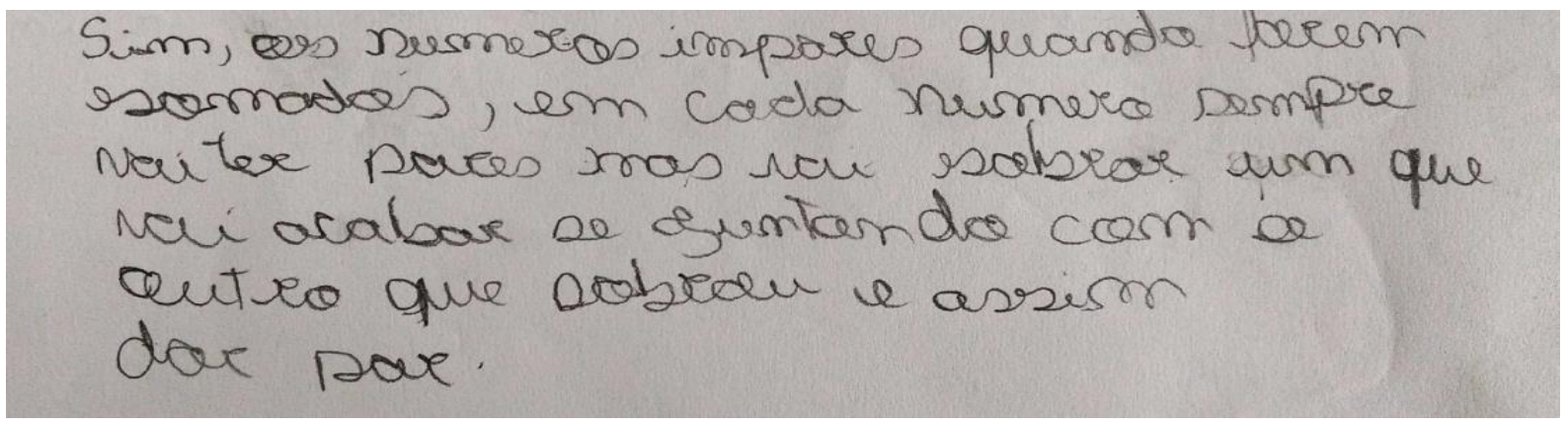

FIGURA 15 - Resposta do aluno F - Atividade 1 - reaplicação - Questão 1

$\mathrm{O}$ argumento acima carrega consigo toda a essência da prova matemática dita por Balacheff (1987) como intelectual. Porém, o aluno utiliza apenas a língua materna, mesmo pensando em um caso geral. Não há exemplos. O argumento, embora não utilize uma linguagem matemática, apresenta as razões para a validade da proposição. Nas pesquisas realizadas por Balacheff (1987) ou Sowder e Harel (1998), em geral, casos como estes são desenvolvidos a partir de uma linguagem matemática, o que dificulta a nossa análise quanto ao enquadramento do argumento em relação as tipologias dos pesquisadores citados. Caso o estudante tivesse utilizado a linguagem matemática, certamente caracterizaríamos tal prova como um experimento mental segundo a tipologia proposta por Balacheff. O desafio passa a ser o da utilização da linguagem de códigos que seja facilitadora para argumentos futuramente desenvolvidos pelo aluno F.

O ponto mais importante é a evolução do aluno se compararmos os dois questionários aplicados. Para a mesma questão, na primeira aplicação, o aluno havia argumentado que:

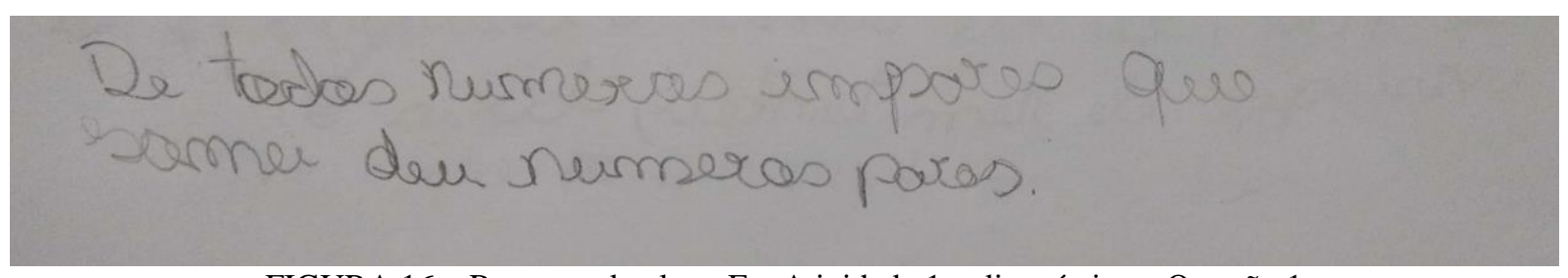

FIGURA 16 - Resposta do aluno F - Atividade 1 - diagnóstica - Questão 1

Devemos considerar que a discussão com os alunos levantou a possibilidade de a soma de dois números ímpares não resultar em um número par, o que motiva o estudante a realmente formular argumentos para provar a veracidade da afirmação: a soma de dois números ímpares é um número par. A melhora dos argumentos apresentados pelo aluno F se deve principalmente a essa motivação da prova que, segundo De Villiers (2001), é uma função essencial para que o 
desenvolvimento de uma prova faça sentido. O aluno precisa observar a necessidade de provar, a necessidade de generalização. Na segunda atividade, certamente o aluno F questiona sobre a importância de se pensar em um caso geral.

$\mathrm{O}$ aluno E utilizou uma linguagem matemática e mostrou que entende que todo número par pode ser escrito como $2 n$, para todo $n \in \mathbb{N}$. Ele inclusive provou, na primeira linha de sua argumentação, que a soma de dois números pares quaisquer (não necessariamente iguais) é sempre par. No entanto, falta dar um passo para poder representar um número ímpar qualquer. Se o aluno E tivesse dados esse passo, teria elaborado uma demonstração.

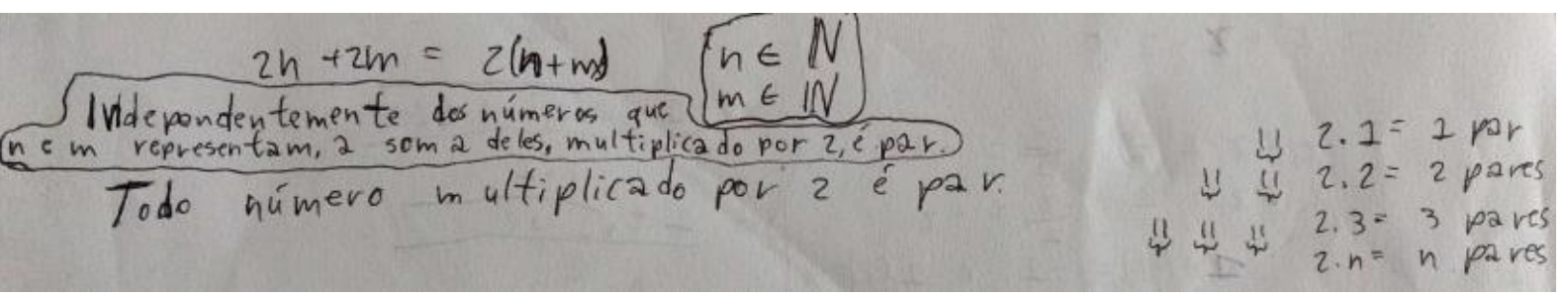

FIGURA 17 - Resposta do aluno E - Atividade 1 - reaplicação - Questão 1

Segundo a tipologia desenvolvida por Balacheff, sua ideia continua muito próxima de uma prova intelectual. Vale ressaltar que o estágio de sua prova estava distante das provas de seus colegas de turma.

O aluno E, quando respondeu o questionário 1, representou por “ $a$ ” um número qualquer e calculou $a+a$ para concluir que a soma era par (vide Figura 9). Nossa intervenção foi a de mostrar ao aluno E que ele estava somando dois números pares iguais e que agora ele precisava pensar em como argumentar no caso da soma de números ímpares quaisquer, distintos.

Acreditamos que o incentivo aos testes tenha auxiliado o aluno $\mathrm{E}$ a tentar generalizar a sua ideia para dois ímpares quaisquer. Embora a prova ainda não seja a ideal para a questão, percebemos que o pensamento e argumentação estão mais próximas das provas consideradas formais. Vale salientar que, após a aplicação da questão, o aluno nos procurou com o objetivo de testar a sua prova. Em poucos minutos, o próprio aluno desenvolveu em lousa uma prova para soma de dois ímpares, do tipo $2 n+1$ e $2 m+1$, com $n$ e $m \in \mathbb{N}$.

Em geral observamos evolução nas provas apresentadas para a questão 1, como evidencia a tabela, com as tabulações baseadas na tipologia de Balacheff (1987), representada a seguir: 


\begin{tabular}{|l|c|c|}
\hline \multicolumn{1}{|c|}{ Tipo de prova } & $\begin{array}{c}\text { Número de alunos } \\
1^{\underline{a}} \text { aplicação }\end{array}$ & $\begin{array}{c}\text { Número de alunos } \\
2^{\underline{a}} \text { aplicação }\end{array}$ \\
\hline Empirismo ingênuo & 16 & 12 \\
\hline Experimento crucial & 1 & - ---------- $^{-1}$ \\
\hline Exemplo genérico & 1 & 4 \\
\hline Experimento Mental & 4 & \\
\hline $\begin{array}{l}\text { Resposta sem justificativa/ } \\
\text { argumento não classificado. }\end{array}$ & & \\
\hline
\end{tabular}

TABELA 8. Questão 1 - Comparação entre a atividade 1 e a reaplicação

Também nos chamou atenção o fato dos mesmos 4 alunos apresentarem respostas sem justificativas, o que nos mostra a dificuldade desses estudantes em reconhecer padrões. Nesse caso, acreditamos que a falta de conhecimento matemático dificulta o desenvolvimento de qualquer argumentação por parte dos estudantes.

Nas respostas apresentadas para a questão 2, no que se refere a segunda aplicação, observamos grande melhora quanto a percepção de padrões. Comparando os resultados das duas aplicações, temos:

\begin{tabular}{|l|c|c|}
\hline \multicolumn{1}{|c|}{ Conclusão } & $\begin{array}{c}\text { Número de alunos } \\
1^{\text {a }} \text { aplicação }\end{array}$ & $\begin{array}{c}\text { Número de alunos } \\
\text { Atividade 2 }\end{array}$ \\
\hline Juan fará 11 gols & 18 & 8 \\
\hline Outro valor & 5 & 1 \\
\hline $\begin{array}{l}\text { Argumento de que não é possível } \\
\text { concluir. }\end{array}$ & -------- & \\
\hline
\end{tabular}

TABELA 9. Questão 2 - Comparação entre a atividade 1 e a reaplicação

Visivelmente a estratégia sugerida por Sowder e Harel (1998) de pensar em sequências numéricas em que os padrões "falham" para testes além dos realizados foi causa importante para que os alunos analisassem outros fatores por detrás da questão apresentada. É claro que, em geral, futuramente trabalharemos com questões que exigirão um desenvolvimento matemático maior, mas acreditamos que a questão 2 serviu como um bom parâmetro das 
dificuldades que podemos encontrar como professor, e o que podemos fazer em contrapartida para que haja evolução na análise e argumentação de nossos alunos.

Após a discussão sobre a atividade diagnóstica, também notamos que a maioria dos alunos procurou argumentar com base em suas resoluções sobre as raízes da equação de $2^{\mathfrak{o}}$ grau apresentadas na questão 3. Comparando, temos:

\begin{tabular}{|l|c|c|}
\hline \multicolumn{1}{|c|}{ Tipo de argumento apresentado } & $\begin{array}{c}\mathrm{N}^{\circ} \text { de alunos } \\
\text { Atividade 1 }\end{array}$ & $\begin{array}{c}\mathrm{N}^{\circ} \text { de alunos } \\
\text { Atividade 2 }\end{array}$ \\
\hline $\begin{array}{l}\text { Argumento com base somente na afirmação da } \\
\text { autoridade }\end{array}$ & 10 & 3 \\
\hline $\begin{array}{l}\text { Argumentação por meio de cálculo correto das raízes. } \\
\text { Argumentação por meio de cálculo incorreto das } \\
\text { raízes. }\end{array}$ & 5 & -11 \\
\hline $\begin{array}{l}\text { Respostas parcialmente corretas, mas sem } \\
\text { argumentação matemática / Sem respostas. }\end{array}$ & 2 & 9 \\
\hline
\end{tabular}

TABELA 10. Questão 3 - Comparação entre a atividade 1 e a reaplicação

Quanto às mudanças dos argumentos apresentados pelos alunos, destacamos dois momentos importantes:

- A análise de um erro de uma autoridade no assunto fez com que os alunos levassem em consideração a possibilidade de erros quanto as respostas do livro.

- A discussão em grupo sobre a $1^{a}$ aplicação fez com que os alunos se motivassem a verificar se a afirmação era realmente verdadeira.

Mais uma vez as propostas de Sowder e Harel (1998) geraram resultados satisfatórios quanto ao desenvolvimento da argumentação de nossos alunos. Podemos notar, da primeira para a segunda aplicação, casos em que os alunos buscam a verificação sobre a veracidade da afirmação, o que é segundo De Villiers (2001) função fundamental da prova. Neste ponto, ressaltamos que as obras que estudamos ao longo de nossa pesquisa bibliográfica são, em geral, complementares, e vemos essa ligação entre as pesquisas como um fator essencial, não somente como pesquisadores, mas principalmente como professores de Matemática. 


\section{Atividade 2 - Soma e Produto de raízes de uma equação do $2^{\circ}$ grau}

Nesta atividade, trouxemos o tema soma e produto das raízes de uma equação polinomial de $2^{\circ}$ grau, que fora trabalhado durante os 40 dias de aula que antecederam a aplicação.

Como já informado, quando ministramos as aulas sobre soma e produto das raízes de uma equação de $2^{\text {o }}$ grau, nenhuma demonstração foi realizada. Propositadamente apenas apresentamos os resultados, sem argumentações ou justificativas. Posteriormente aplicamos em alguns exemplos. Aparentemente, isso foi suficiente para o convencimento da turma. A pergunta se você acredita que o aluno não está certo, quais são as relações corretas? Justifique a sua resposta propõe a necessidade de um argumento, que pode ser reconhecido como uma recorrência a autoridade ou, o que é o ideal, provas a partir de teoremas descobertos anteriormente.

Analisando as respostas, notamos novamente problemas já apresentados nas atividades anteriores, pois muitos alunos não procuraram maneiras de comprovação da afirmação fornecida durante as aulas de Matemática, como por exemplo o aluno E, que diz:

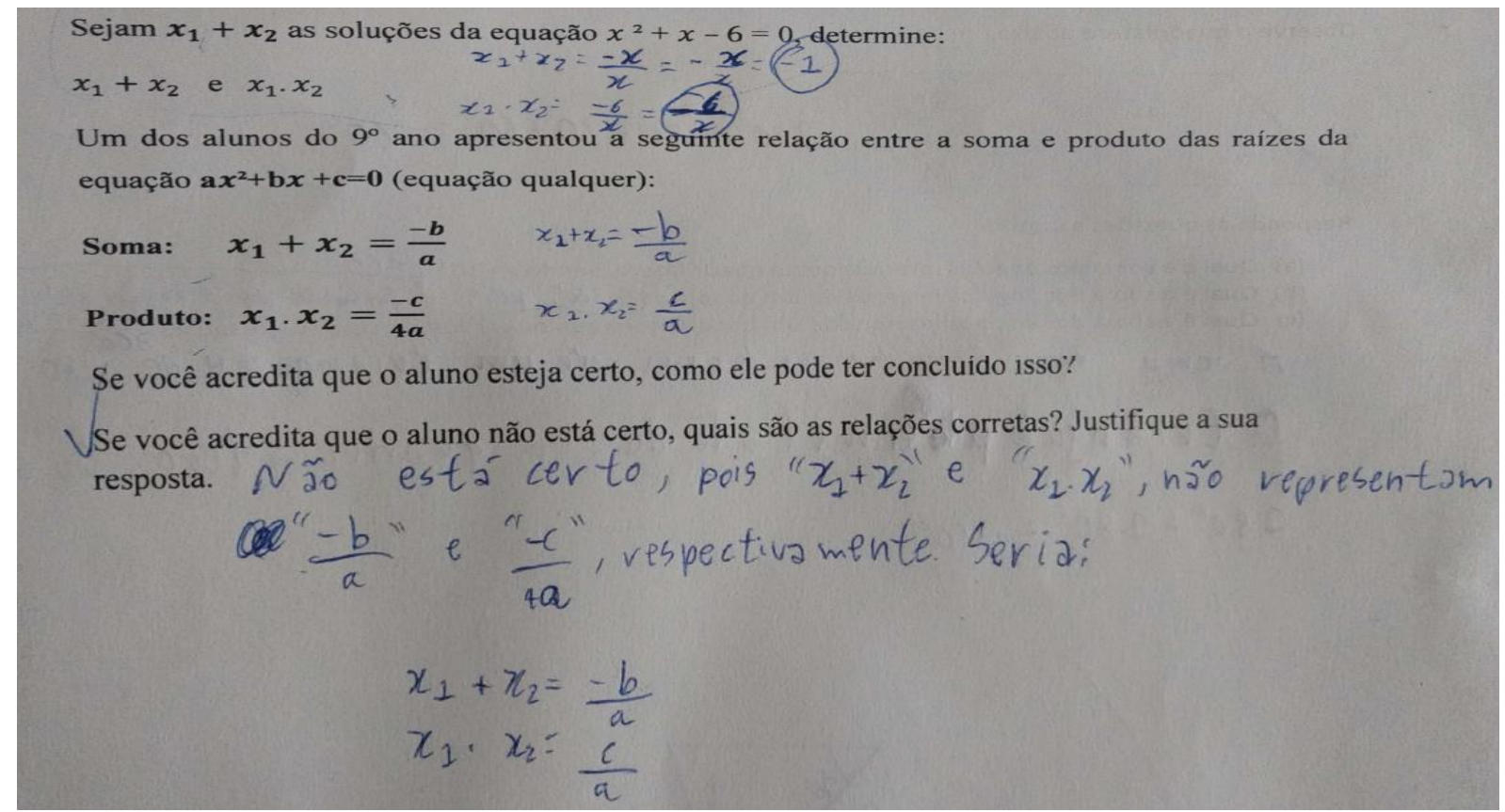

FIGURA 18 - Resposta do aluno E - Atividade 2

Embora possamos notar evolução se compararmos com as primeiras atividades, tivemos novamente um baixo desempenho ao analisarmos toda a turma, tendo em vista que, classificando os argumentos segundo a tipologia desenvolvida por Sowder e Harel (1998), temos: 


\begin{tabular}{|l|c|}
\hline \multicolumn{1}{|c|}{ Classificação } & Número de alunos \\
\hline $\begin{array}{l}\text { Esquema de prova autoritário / esquema de } \\
\text { prova baseado em exemplos }\end{array}$ & 5 \\
\hline Esquema de prova ritual & 1 \\
\hline Esquema de prova axiomático & 15 \\
\hline Respostas incorretas ou sem justificativas & \\
\hline
\end{tabular}

TABELA 11. Tabulação - Atividade 2

O primeiro ponto a observar é que as provas foram classificadas como esquema de prova autoritário/esquema de prova baseado em exemplos de forma conjunta pois, ao estudarmos o conteúdo anteriormente, o aluno já tinha conhecimento do resultado, tanto pelo fato de ser apresentada por um professor ter visto no livro de Matemática, quanto pelas várias resoluções de problemas propostas durante as semanas que precederam a aplicação da atividade.

O segundo ponto é que, novamente, a dificuldade na argumentação esbarra nos problemas dos alunos quanto ao entendimento do conteúdo matemático.

A terceira observação é de que a pergunta, da maneira como foi formulada, pode direcionar para uma resposta sem que ocorra nenhuma argumentação. Sendo assim, acreditamos que o questionário não propiciou o desenvolvimento do nível de argumentação de nossos alunos.

A observação nos leva a traçar novas estratégias que visam a discussão das respostas desenvolvidas pelos alunos. A aluna B não participou de nenhuma discussão durante a realização da atividade, e certamente teria muito a contribuir com a turma com relação a sua argumentação. Para as próximas atividades, nos baseando nas práticas defendidas por Nasser e Tinoco (2003) e Sowder e Harel (1998), expomos algumas das respostas desenvolvidas pelos alunos e incentivamos discussões no momento da realização da atividade. É exatamente o que Balacheff (1987) chama de Interação social. Isso tende a auxiliar no desenvolvimento de argumentações e provas matemáticas por parte de nossos estudantes. 


\section{Atividade 3 - Trigonometria no triângulo retângulo}

O planejamento inicial previa a aplicação de duas atividades para realização de nossa pesquisa. Porém utilizamos características da metodologia design experiments, o que nos habilitou a replanejar as atividades com base nas observações realizadas a partir das aplicações anteriores. Resolvemos verificar o desenvolvimento de argumentos de nossos alunos para questões de conteúdos trabalhados durante as aulas de Matemática. O tema escolhido foi trigonometria no triângulo retângulo, proposto para o terceiro trimestre pela base curricular municipal. A atividade foi aplicada, aproximadamente, 90 dias após a realização da atividade diagnóstica 1, e visa concluir sobre possíveis evoluções dos estudantes quanto ao desenvolvimento da habilidade de provar, tendo em vista que, durante as aulas do período, valorizamos as argumentações realizadas pelos alunos seguindo as estratégias propostas principalmente por Rezende e Nasser (1994), Nasser e Tinoco (2003) e Sowder e Harel (1998).

Propusemos aos alunos a questão:

Já concluímos, usando um triângulo equilátero de lado L, que cosseno de $30^{\circ}$ é igual a $\frac{\sqrt{3}}{2}$. Agora, utilize um quadrado qualquer para concluir sobre cosseno de $45^{\circ}$ e tangente de $45^{\circ}$.

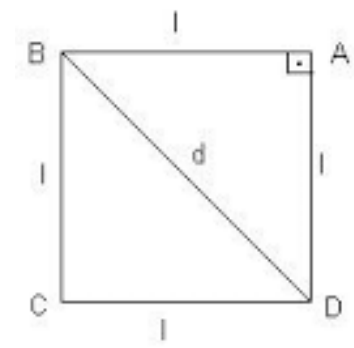

Diferentemente das primeiras atividades, considerando que alguns alunos não estiveram presentes na escola no dia em que a atividade 3 foi aplicada, apenas 17 alunos participaram desta etapa. Todos os estudantes presentes participaram das atividades anteriores. O tema trigonometria no triângulo retângulo fora trabalhado nas 3 aulas que antecederam a aplicação. É importante ressaltar que utilizamos, desde o início da aplicação, estratégias que visavam facilitar o desenvolvimento de argumentações e provas de nossos alunos, tais como as defendidas por Nasser e Tinoco (2003):

- discussão em grupo das ideias de respostas ;

- avaliação em lousa de justificativas apresentadas pelos alunos ; 
- discussão em grupo de conhecimentos que já foram estudados e que serão utilizados na resposta.

A importância de se pensar em uma medida qualquer para o lado do quadrado já havia sido discutida quando trabalhamos com triângulos para concluir sobre o seno, cosseno e tangente de $30^{\circ}$.

O fato de termos definido em sala a utilização de um quadrado de lado qualquer, fez os alunos representarem diretamente as suas ideias com símbolos, o que em alguns casos implicou em expressões sem sentido argumentativo, como, por exemplo, a resposta dos alunos $\mathrm{C}$ e I:

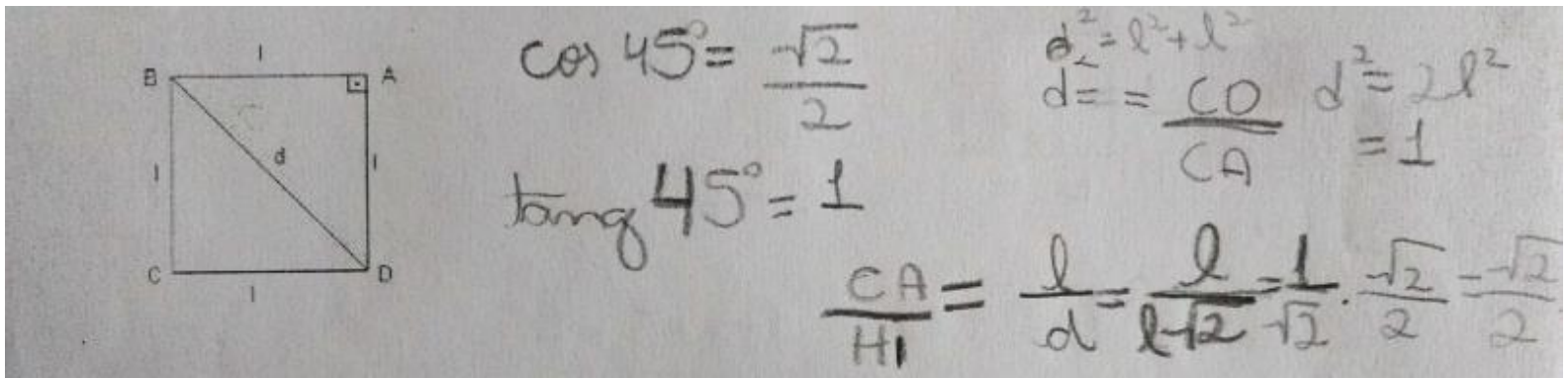

FIGURA 19 - Resposta do aluno C - Atividade 3

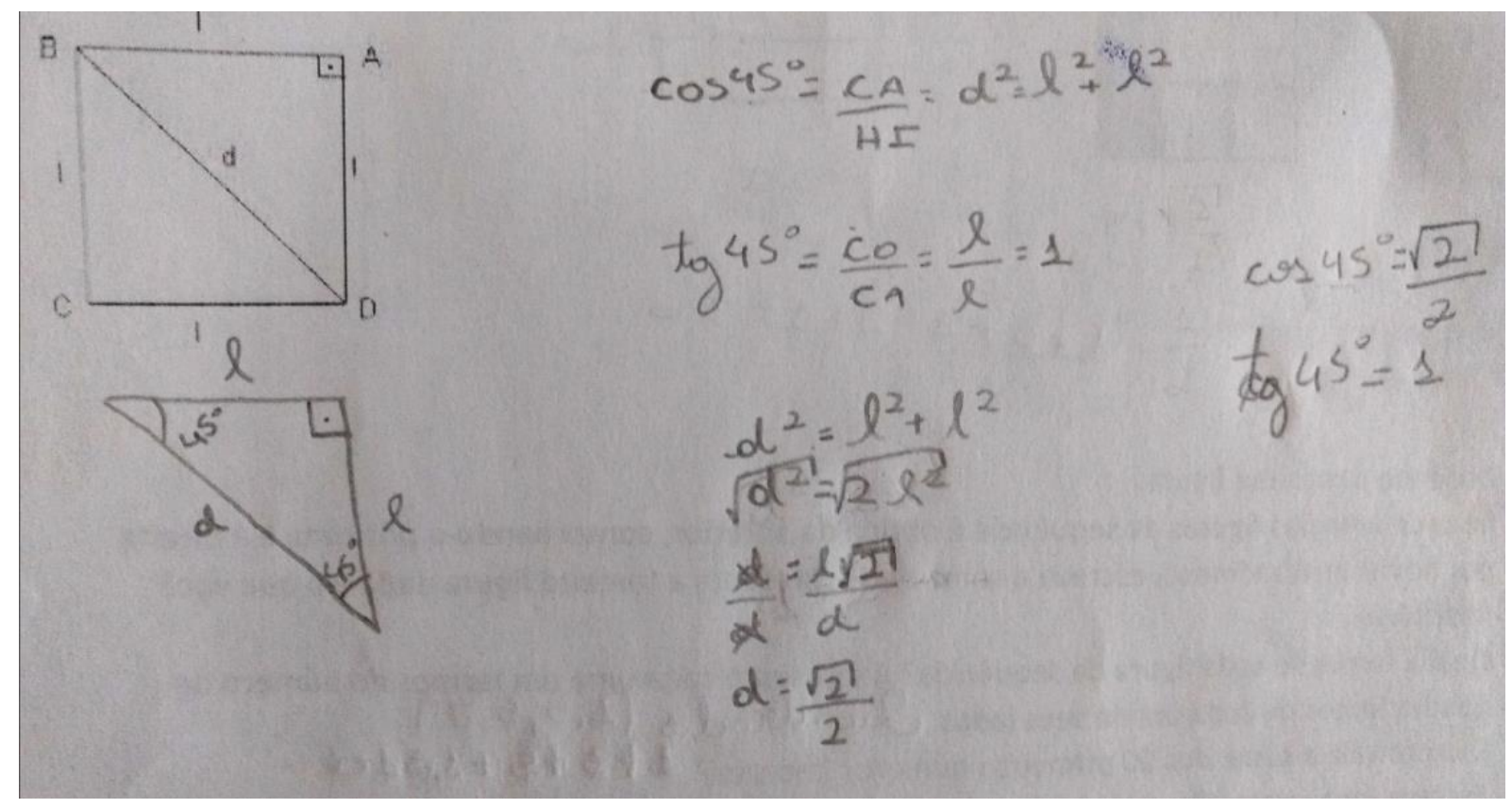

FIGURA 20 - Resposta do aluno I - Atividade 3 
É notória a tentativa de encontrar uma expressão a todo custo, a partir de símbolos que, no argumento, não trazem significado para as relações que se tem no triângulo obtido por meio da diagonal do quadrado.

Os dois casos citados são exemplos claros do que Sowder e Harel (1998) denominam de esquema de prova ritual, em que a linguagem matemática é uma espécie de necessidade durante a argumentação, entretanto não apresenta nenhum questionamento quanto a sua validade. Os símbolos são utilizados de maneira decorada, ou espelhada em alguma autoridade. $\mathrm{Na}$ atividade em questão, a autoridade no assunto foram os próprios colegas de classe que desenvolveram provas que os convenceram.

Entretanto, algumas respostas sugerem importante desenvolvimento quanto a argumentação e prova de alguns estudantes. Por exemplo, o aluno $\mathrm{H}$ argumenta da seguinte forma:

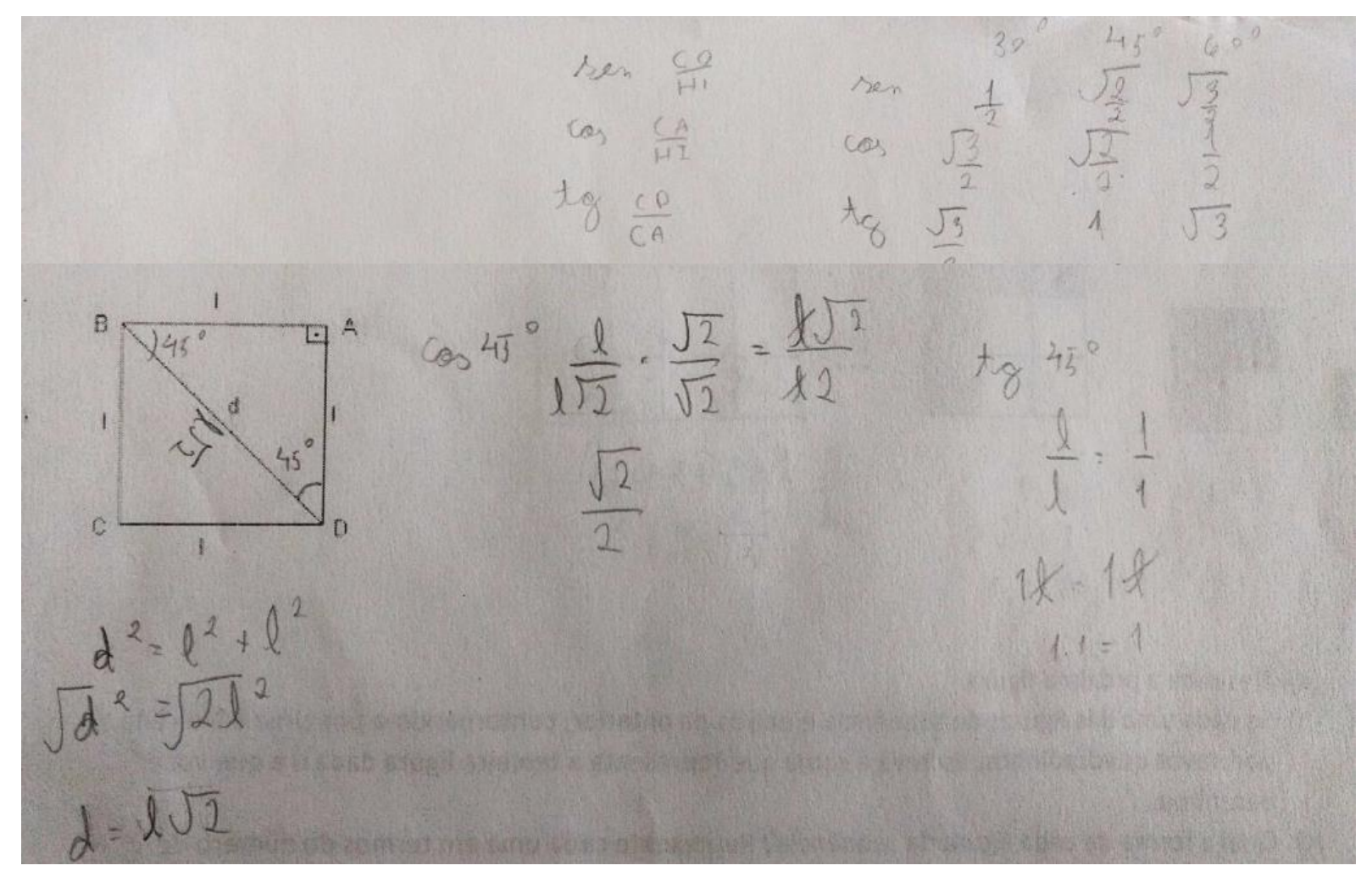

FIGURA 21 - Resposta do aluno H - Atividade 3

Vale ressaltarmos alguns pontos:

- a prova é realizada em uma linguagem matemática, o que mostra evolução ao compararmos com outras provas analisadas anteriormente; 
- há uma tabela com os valores notáveis na parte superior da folha de respostas do aluno $\mathrm{H}$, mesmo que os valores da tabela não tinham sido trabalhados até o momento em sala de aula. $\mathrm{O}$ fato sugere que o estudante pesquisou e já estava convencido dos valores de $\cos \left(45^{\circ}\right)$ e $\operatorname{tg}\left(45^{\circ}\right)$. Dessa forma, a função descrita por De Villiers (2001) como descoberta não se aplica ao desenvolvimento do argumento do aluno $\mathrm{H}$;

- durante a resolução da questão, vimos que algumas vezes a discussão entre os alunos era sobre a veracidade desses valores. De alguma forma, os alunos haviam pesquisado sobre os valores das razões trigonométricas para os ângulos notáveis. De acordo com Balacheff (1987), agora os alunos estavam discursando com o objetivo de tornar compreensível a veracidade dos valores das razões trigonométricas que foram pesquisadas, mesmo recorrendo as autoridades, no caso sites, vídeos na internet e livros didáticos, ou seja, buscavam uma explicação. Porém, logo teriam que desenvolver uma prova, pois teriam que convencer a comunidade, o que certamente geraria discussões sobre o sistema de validação.

Segundo a tipologia de provas desenvolvida por Balacheff (1987), temos um exemplo de prova intelectual, mais precisamente um experimento mental. Claro, ainda não estamos pensando e nem comparando com demonstrações realizadas de forma axiomática, tampouco complexas que normalmente temos expostas em livros ou artigos da comunidade matemática.

De acordo com Sowder e Harel (1998), os argumentos do aluno H formam uma prova contida no esquema de prova analítico e, de acordo com Rezende e Nasser (1994), uma prova formal.

A fim de analisar os resultados de nossa última aplicação, tabulamos as provas desenvolvidas pelos alunos segundo a tipologia de Sowder e Harel (1998):

\begin{tabular}{|l|c|}
\hline \multicolumn{1}{|c|}{ Classificação } & Número de alunos \\
\hline Esquema de prova ritual & 2 \\
\hline Esquema de prova axiomático & 3 \\
\hline Respostas incorretas ou sem justificativas & 12 \\
\hline
\end{tabular}

TABELA 12. Tabulação - Atividade 3 
Acreditamos que a função da descoberta, como define De Villiers (2001), fez com que os alunos discutissem possíveis respostas para o problema. Notamos, durante as aulas de aplicação da atividade, que os estudantes trocavam informações sobre os valores obtidos a partir de argumentações e comparavam as suas respostas. Entretanto, vários alunos não conseguiram construir a argumentação que esperávamos.

Muitos dos alunos que classificamos suas respostas como "Respostas incorretas ou sem justificativas" escreveram expressões que, segundo Sowder e Harel (1998), se aproximam de um esquema de prova ritual, ou ainda de um esquema de prova autoritário pois se basearam nas provas desenvolvidas por seus colegas. Notamos que a falta de conhecimento de conteúdos matemáticos, que são alicerces para entender o significado de tangente e cosseno de um ângulo, tornaram o desenvolvimento da prova sugerida inviável. Muitos alunos não diferenciaram o cateto oposto do cateto adjacente a um ângulo. Dessa forma, acreditamos que a atividade não convinha para todos os alunos da turma no momento da aplicação, ao menos de um ponto de vista do desenvolvimento de provas.

O resultado da atividade 3 nos fez pensar que devemos fazer um diagnóstico melhor de quais conteúdos os alunos estão aptos para aprender e, consequentemente, quais provas podem ser propostas para desenvolvimento por esses estudantes. Algo que certamente usaremos, tanto como pesquisadores, quanto como professores de Matemática da Educação Básica.

\subsection{Proposta de atividades}

Após o processo de elaboração das atividades e o resultado do desenvolvimento com os alunos, conseguimos visualizar alguns pontos que podem ser aprimorados. É o caso de uma atividade envolvendo a soma dos ângulos internos de um quadrilátero.

A atividade, na primeira versão, era a seguinte:

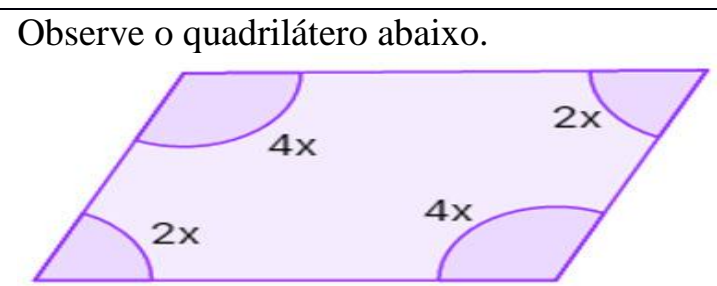

Responda as questões a seguir:

(a) Qual é a soma das medidas dos ângulos internos desse quadrilátero, sendo $x=30^{\circ}$.

(b) Qual é a soma das medidas dos ângulos internos de um quadrado? 
(c) Qual é a soma das medidas dos ângulos internos de um quadrilátero qualquer? Justifique a sua resposta.

Concluímos que poderíamos ter proposto um processo maior de experimentação, ou seja, permitir que o aluno possa formular uma conjectura sobre a soma dos ângulos internos por meio de um convencimento próprio.

Dessa forma, com base nas propostas de Nasser e Tinoco (2003) e Sowder e Harel (1998), reelaboramos a atividade.

\section{Atividade - Versão 2}

\section{Justificativa}

Para melhorar o nível de argumentação e prova, Sowder e Harel (1998) e De Villiers (2001) indicam que os alunos devem fazer experimentações, observar padrões e formular hipóteses. Com esta atividade, os estudantes poderão realizar argumentações com base em conhecimentos matemáticos já adquiridos até formular e provar uma afirmação de que a soma das medidas dos ângulos internos de um quadrilátero é $360^{\circ}$. Nesse caso, uma das funções da prova descritas por De Villiers (2001) que pode ser observada nesta atividade é a de descoberta, já que o estudante não tem certeza sobre o resultado. Entretanto, as funções comunicação e explicação podem fazer parte da atividade no momento em que os alunos trocarem informações e opiniões entre si sobre possíveis argumentos.

\section{Atividade - Versão 2}

Folha 1

(a) Determine a soma dos ângulos internos dos quadriláteros abaixo:
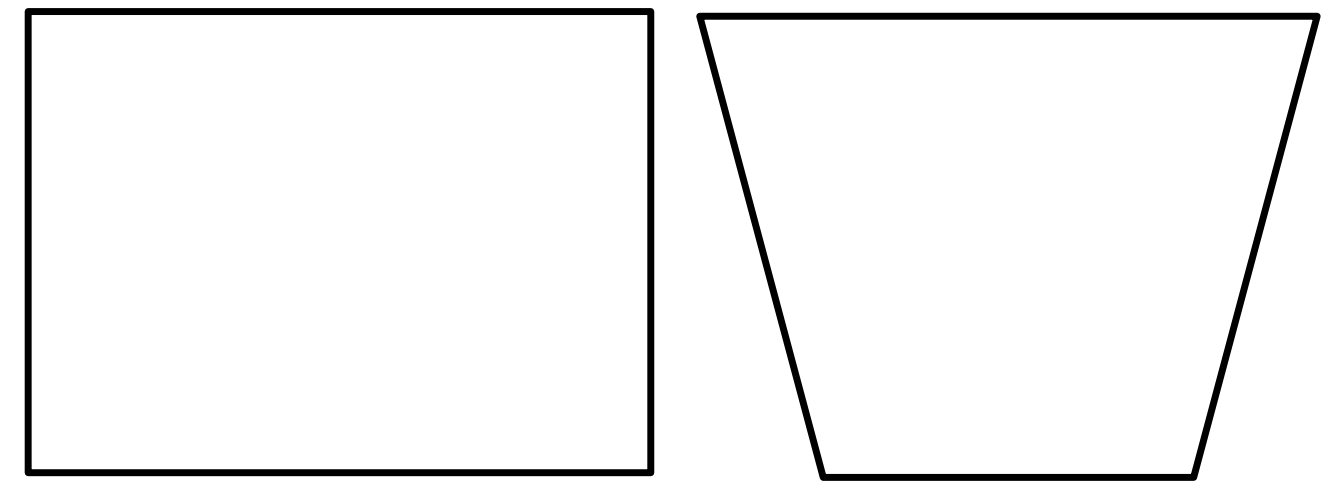


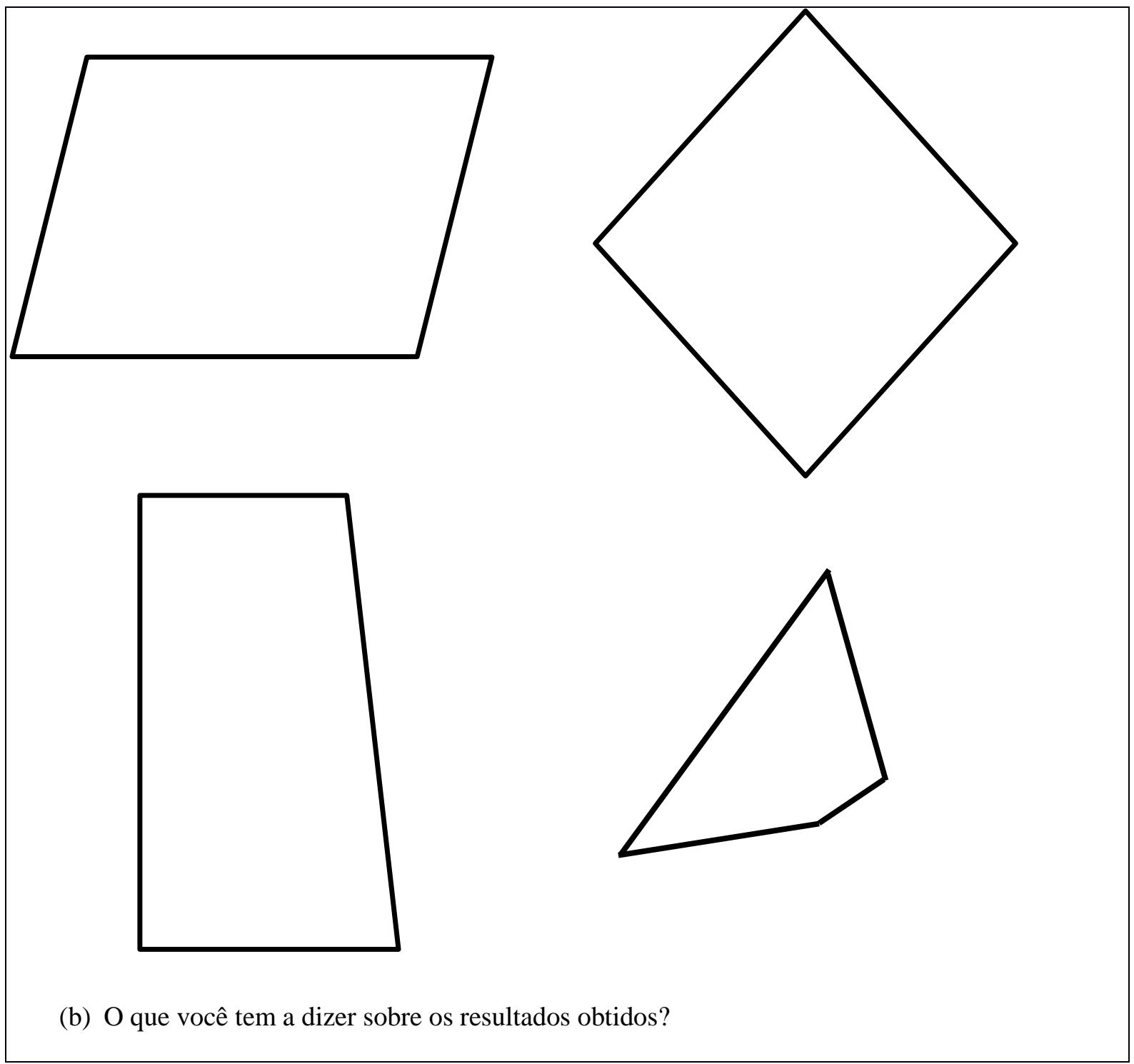

Folha 2

(c) Você já estudou que a soma das medidas dos ângulos internos de qualquer triângulo é $180^{\circ}$. Discuta com seus colegas e verifique se há valor fixo ao somar os ângulos internos de qualquer quadrilátero, assim como acontece com os triângulos.

\section{Comentários para o professor}

No item (a) o aluno poderá usar transferidor para medir os ângulos internos de cada quadrilátero e efetuar a soma. O professor deverá estar atento a possíveis erros de medição. É 
esperado que os alunos encontrem números próximos de $360^{\circ}$, já que, em teoria, é esse o valor da soma dos ângulos internos de um quadrilátero.

Após o processo de experimentação, o professor deve propor a questão (b). Neste ponto, caso os alunos não cheguem ao valor de $360^{\circ}$, o professor pode incentivá-los a calcular as medidas novamente, priorizando a comunicação entre os estudantes para comparações de resultados. Em último caso, o professor tem a opção de realizar as medições e perguntar ao aluno: o que você vê em comum entre essas somas?

Entretanto, é possível que alguns alunos percebam que o quadrilátero pode ser subdividido em 2 triângulos e chegar à resposta correta mais rapidamente.

O item (b) é um passo de descoberta de uma propriedade e é alicerce para formulação de hipótese.

A proposta do item (c) é incentivar a generalização e a necessidade do desenvolvimento de uma prova. Neste momento, é importante que os alunos saibam e reconheçam que a soma dos ângulos internos de um triângulo, na Geometria Euclidiana, é $180^{\circ}$. Como incentivo à argumentação, o professor pode sugerir, no momento em que julgar adequado, a divisão do quadrilátero em dois triângulos, a partir de uma diagonal da figura. A prática de questionar os alunos sobre a conclusão, incentivando debates sobre as possíveis formas de argumentação é uma das ações propostas por Sowder e Harel (1998).

Conforme o desenvolvimento da turma, na sequência o professor poderá propor mais generalizações.

(d) Qual é a soma dos ângulos internos de um pentágono?

(e) Qual é a soma dos ângulos internos de um hexágono?

(f) Qual é a soma dos ângulos internos de um Dodecágono?

(g) Qual é a soma dos ângulos internos de um polígono com $n$ lados?

A partir do item (e), depois que o aluno já aprendeu que pode dividir o polígono em triângulos, a questão passa a ser a quantidade de triângulos obtidos em função do número de lados do polígono.

O professor poderá orientar o aluno no item (g), fazendo-o observar algumas relações importantes nos casos anteriores, a saber que em um polígono de $n$ lados:

I. há $n$ vértices; 
II. há $n-1$ segmentos que ligam um vértice fixado aos outros vértices, sendo que dois deles são lados e, portanto, $n$ - 3 são diagonais;

III. há $n-2$ triângulos construídos dessa forma;

IV. a soma dos ângulos internos é igual a $(n-2) \cdot 180^{\circ}$. 


\section{Justificativa}

\section{Atividade - Equação de segundo grau}

Seguindo as propostas de Sowder e Harel (1998) e De Villiers (2001), a ideia dessa atividade é que o aluno faça experimentações, observe padrões e realize inferências sobre a validade para toda a classe de objetos a partir de seus representantes. Sowder e Harel indicam que os alunos devem trabalhar com temas ainda não abordados, pois isso gera curiosidade sobre resultados, o que vai ao encontro das palavras de De Villiers (2001), quando o autor diz que a função da descoberta é papel importante no processo de desenvolvimento do nível de prova de nossos estudantes.

Outro ponto relevante da atividade é trabalhar com a forma fatorada de uma equação, o que sugere o uso contínuo de argumentações e percepções de padrões.

\section{Parte 1}

\section{Objetivo}

\section{Soma e Produto das raízes}

Perceber a relação entre as raízes e os coeficientes de uma equação do $2^{\circ}$ grau.

a) Complete a tabela, sendo $x_{1}$ e $x_{2}$ as raízes das equações de $2^{\circ}$ grau.

\begin{tabular}{|l|l|l|l|l|}
\hline \multicolumn{1}{|c|}{ Equação } & $\boldsymbol{x}_{\mathbf{1}}$ & $\boldsymbol{x}_{\mathbf{2}}$ & $\boldsymbol{x}_{\mathbf{1}}+\boldsymbol{x}_{\mathbf{2}}$ & $\boldsymbol{x}_{\mathbf{1}} \cdot \boldsymbol{x}_{\mathbf{2}}$ \\
\hline$x^{2}-5 x+6=0$ & & & & \\
\hline$x^{2}-4 x+4=0$ & & & & \\
\hline$x^{2}-10 x+24=0$ & & & & \\
\hline$x^{2}+5 x+4=0$ & & & & \\
\hline$x^{2}+7 x+12=0$ & & & & \\
\hline$x^{2}-2 x-8=0$ & & & & \\
\hline$x^{2}-2 x-35=0$ & & & & \\
\hline$x^{2}-6 x+9=0$ & & & & \\
\hline$x^{2}-3 x+2=0$ & & & & \\
\hline$x^{2}+3 x-10=0$ & & & & \\
\hline$-x^{2}+4 x-3=0$ & & & & \\
\hline$-x^{2}-5 x+14=0$ & & & & \\
\hline $2 x^{2}-12 x-32=0$ & & & & \\
\hline $2 x^{2}-14 x-36=0$ & & & & \\
\hline $3 x^{2}-15 x-150=0$ & & & & \\
\hline
\end{tabular}

b) O que você reparou em relação à soma e produto das raízes e os coeficientes de uma equação de $2^{\circ}$ grau? 
c) Sem o uso da fórmula de Bhaskara, encontre as raízes das seguintes equações:

\begin{tabular}{|l|l|l|l|l|}
\hline \multicolumn{1}{|c|}{ Equação } & $\boldsymbol{x}_{\mathbf{1}}+\boldsymbol{x}_{\mathbf{2}}$ & $\boldsymbol{x}_{\mathbf{1}} \cdot \boldsymbol{x}_{\mathbf{2}}$ & $\boldsymbol{x}_{\mathbf{1}}$ & $\boldsymbol{x}_{\mathbf{2}}$ \\
\hline$x^{2}-x-30=0$ & & & & \\
\hline$x^{2}+2 x-15=0$ & & & & \\
\hline$x^{2}+2 x-24=0$ & & & & \\
\hline$x^{2}-7 x-8=0$ & & & & \\
\hline $2 x^{2}-x-1=0$ & & & & \\
\hline$-x^{2}+3 x+18=0$ & & & & \\
\hline$-2 x^{2}+8 x-6=0$ & & & & \\
\hline $5 x^{2}-25 x+30=0$ & & & & \\
\hline$-2 x^{2}+2 x+84=0$ & & & & \\
\hline$-x^{2}-6 x+7=0$ & & & & \\
\hline
\end{tabular}

d) A relação que você encontrou também serve para a equação $2 x^{2}+5 x+2=0$ ? E para a equação $3 x^{2}+8 x-5=0$ ?

e) Sendo $x_{1} \boldsymbol{e} \boldsymbol{x}_{2}$ as raízes da equação: $a x^{2}+b x+c=0$, o que você pode dizer sobre a relação entre os coeficientes $\boldsymbol{a}, \boldsymbol{b}$ e $\boldsymbol{c}$ e:

$x_{1}+x_{2} ?$

$x_{1} \cdot x_{2} ?$

Justifique a sua resposta.

f) (ENEM 2015 - adaptado) Um estudante está pesquisando o desenvolvimento de certo tipo de bactéria. Para essa pesquisa, ele utiliza uma estufa para armazenar as bactérias. A temperatura no interior dessa estufa, em graus Celsius, é dada pela expressão $T=-h^{2}+22 h-85$, em que $h$ representa as horas do dia.

Sempre que a temperatura da estufa é $0^{\circ} \mathrm{C}$, o aluno faz uma vistoria para ter certeza de que o sistema montado está funcionando corretamente. Em quais horários do dia que esse aluno deve fazer a vistoria? 


\section{Comentários para o professor}

$\mathrm{Na}$ atividade (a) os alunos são convidados a utilizar as experiências já vividas em sala de aula, encontrar as raízes da equação, a soma e o produto entre elas. O professor deve aceitar os diversos caminhos que o estudante tem, seja por testes ou por fórmula descoberta anteriormente.

O item (b) propõe que o aluno exponha a sua visão sobre os padrões observados. Nesse momento, caso haja dificuldades dos alunos em relacionar a soma e o produto das raízes das equações com seus coeficientes, o professor deve propor discussões entre os estudantes, como indicam Sowder e Harel (1998).

No item (c), a proposta é de que o aluno utilize dos padrões já observados na questão (a) e discutidos na questão (b) para encontrar raízes da equação de $2^{\text {o }}$ grau. Repare que o caminho para o item (a) é: Raízes $\longrightarrow$ Soma e Produto. Já no item (c) a intenção é que o estudante faça o caminho Soma e Produto $\longrightarrow$ Raízes. Nessa questão, o professor pode propor observações sobre a relação entre os sinais dos coeficientes e os sinais das raízes encontradas.

A ideia do item (d) é mostrar que a relação pode não ser de fácil aplicação para todas as equações. Entretanto, ao encontrar as raízes e realizar testes, o aluno deve verificar que a relação também é válida para as equações indicadas.

No item (e) o estudante é convidado a trabalhar com o caso geral. Note que as funções descritas por De Villiers (2001) como sistematização e desafio intelectual entram em ação. Além disso, com apoio nas orientações de Nasser e Tinoco (2003) e Sowder e Harel (1998), é importante que haja comunicação entre os estudantes, em que a função de comunicação também pode ser levada em consideração. É importante que o professor esteja atento aos teoremas utilizados pelo aluno para realização da prova, e faça os questionamentos adequados sobre generalização caso o aluno apenas apresente a relação em função dos coeficientes sem se apoiar em algum teorema encontrado anteriormente. É possível que o estudante utilize as duas raízes de uma equação geral encontradas pela fórmula de Bhaskara para determinar sua soma e o produto em termos dos coeficientes $a, b$ e $c$.

A ideia do item (f) é que o estudante aplique a relação descoberta com o objetivo de facilitar a resolução do problema. 


\section{Parte 2}

\section{Objetivo}

\section{Encontrar as raízes por fatoração}

Encontrar as raízes de uma equação de $2^{\circ}$ grau pela forma fatorada.

a) Sabendo que o produto de dois números só é igual a zero se um dos fatores for zero, responda:

$$
\text { Quais são as raízes da equação }(x-2) \cdot(x-5)=0
$$

b) Encontre as raízes da equação $x^{2}+7 x+10=0$.

c) O que você notou em relação às raízes das equações nos itens (a) e (b)?

d) Qual das duas equações você resolveu mais rapidamente? Por que acredita que isso tenha acontecido?

Você sabia que, em Matemática, duas equações que têm as mesmas raízes são ditas equivalentes?

e) Desenvolva o produto $(x-2) \cdot(x-5)$ ? O que você notou em relação ao item (b)?

f) Qual a relação entre as raízes e cada fator da expressão do item (a)?

g) Preencha a tabela, multiplicando os fatores dados ou fatorando a expressão.

\begin{tabular}{|l|l|}
\hline \multicolumn{1}{|c|}{ Forma fatorada } & \multicolumn{1}{c|}{ Equação não fatorada } \\
\hline$(x-2) \cdot(x-3)=0$ & $x^{2}-5 x+6=0$ \\
\hline $2(x-2) \cdot(x-2)=0$ & $2 x^{2}-8 x+8=0$ \\
\hline & $x^{2}-x-30=0$ \\
\hline & $x^{2}-10 x+24=0$ \\
\hline & $x^{2}+5 x+4=0$ \\
\hline$x(x+4)$ & $2 x^{2}-x-1=0$ \\
\hline$-x(x-6)$ & \\
\hline
\end{tabular}




\begin{tabular}{|l|l|}
\hline$-(x-6) \cdot(x+3)=0$ & \\
\hline & $-2 x^{2}+8 x-6=0$ \\
\hline & $5 x^{2}-25 x+30=0$ \\
\hline$-(x-1) \cdot(x+7)=0$ & $-2 x^{2}+2 x+84=0$ \\
\hline
\end{tabular}

h) Determine as raízes das equações dadas, por meio de fatoração.

\begin{tabular}{|l|l|l|}
\hline \multicolumn{1}{|c|}{ Equações } & $x_{1}$ & $x_{2}$ \\
\hline$x^{2}-5 x+6=0$ & & \\
\hline $2 x^{2}-8 x+8=0$ & & \\
\hline$x^{2}-x-30=0$ & & \\
\hline$x^{2}-10 x+24=0$ & & \\
\hline$x^{2}+5 x+4=0$ & & \\
\hline $2 x^{2}-x-1=0$ & & \\
\hline$-2 x^{2}+8 x-6=0$ & & \\
\hline $5 x^{2}-25 x+30=0$ & & \\
\hline$-2 x^{2}+2 x+84=0$ & & \\
\hline
\end{tabular}

\section{Comentários para o professor}

$\mathrm{Na}$ atividade (a) a proposta é que o aluno perceba que pode resolver a equação igualando cada um dos fatores a zero. Nesse momento, o professor pode mostrar-lhes mais alguns casos ou propor discussões entre os alunos sobre a validade dessa propriedade, como sugerem Sowder e Harel (1998).

No item (b) o aluno deve resolver a equação da maneira mais confortável para ele. O item (c) propõe a comparação dos resultados encontrados nos itens anteriores. O professor deve se certificar que as raízes encontradas são as mesmas. Caso contrário, pode pedir que seus alunos comparem os resultados e discutam sobre a veracidade de cada um deles.

$\mathrm{Na}$ atividade (d) o professor deve incentivar a comparação das duas maneiras de resolução. Caso nenhum aluno perceba, o professor pode fazer a observação de que, no item (a) o grau das equações resolvidas separadamente é menor do que o grau da equação proposta no item (b).

Na questão (e) a atividade chama a atenção para a equivalência das equações dos itens (a) e (b). O professor pode propor um número maior de experimentações, como indicam Nasser e Tinoco (2003), dependendo do que notar no desenvolvimento da atividade, observando que a tomada de decisão sobre a forma mais simples de encontrar as raízes de uma equação é sempre do próprio estudante. 
A atividade (f) propõe a observação da relação entre os fatores e as raízes da equação proposta no item (a). Nos apoiando nas estratégias de Sowder e Harel (1998), o professor pode propor discussões sobre esses ou mais exemplos, .

O item (g) incentiva a observação da relação entre várias equações desenvolvidas e suas respectivas fatorações, além de fazer com que o estudante descubra a relação entre os fatores e os coeficientes $a, b$ e $c$ da equação $a x^{2}+b x+c=0$.

No item (h) a proposta é que o aluno utilize a forma fatorada para encontrar as raízes da equação sempre que for conveniente. O professor pode fazer a observação para o caso de raízes irracionais, em que convém o uso da fórmula de Bhaskara.

Ressaltamos que, tanto para a parte 1, quanto para a parte 2, é importante que os itens sejam propostos de forma dependente, ou seja, o item (b) deve ser proposto apenas após a conclusão e discussões em torno do item (a), o item (c) seja abordado após os alunos responderem o item (b) e assim por diante. 


\section{Conclusões}

Nossa pesquisa nos mostrou a importância da existência de atividades que propiciem o desenvolvimento da habilidade de argumentar e provar por parte de nossos alunos da Educação Básica e, principalmente, quais os tipos de atividades que facilitam o melhoramento do nível de argumentação.

Nos baseando em trabalhos como os de De Villiers (1991 e 2001), Sowder e Harel (1998), Nasser e Tinoco (2003) concluímos que o ensino de Matemática, sob a visão da elaboração de argumentos e provas matemáticas, tende a contribuir com desenvolvimento do raciocínio dedutivo e tomada de decisão sobre a veracidade de afirmações.

Embora seja evidente a importância da inclusão do desenvolvimento de provas por parte de nossos alunos durante as aulas de Matemática, notamos que não há evidências de que os materiais utilizados pelas escolas de Barueri, como apostilas ou livros didáticos, facilitem o desenvolvimento das habilidades que envolvem a argumentação e prova matemática. Mais do que isso, nos documentos que norteiam a Educação de Barueri não há menção a objetivos que envolvam desenvolvimento dessas habilidades. Entretanto, os PCN deixam claro a relevância da capacidade de argumentação na formação de cada um de nossos educandos. Nesse sentido, o trabalho de Pietropaolo (2005) nos mostrou que há necessidade e diversas possibilidades de inclusão do tema argumentação e prova no Currículo de Matemática.

Retomando as perguntas que nortearam esse trabalho, a primeira questão é:

- Como trabalhar as situações que envolvem a argumentação e prova matemática na Educação Básica?

A questão foi respondida a partir da leitura dos trabalhos contidos em nossas referências bibliográficas, tais como as pesquisas desenvolvidas por Pietropaolo (2005), Boa Vida (2005), Sowder e Harel (1998) e Nasser e Tinoco (2003). Assumindo a importância do desenvolvimento das habilidades de argumentação e prova na Educação Básica, o professor de Matemática deve estar ciente do significado da palavra prova no ensino de Matemática, se desprendendo da visão de que a prova matemática é caracterizada unicamente por um processo 
axiomático, como na maioria das vezes é aceita pela comunidade matemática. Nesse sentido, o docente, que tem papel fundamental nessa problemática, deve levar em consideração as funções da prova matemática na Educação Básica como, por exemplo, mostram os trabalhos de De Villiers (1991 e 2001). Outro ponto importante da visão do professor é o de reconhecer os diversos tipos de provas que podem ser desenvolvidas pelos alunos, podendo, por exemplo, se basear nas tipologias de provas desenvolvidas por Balacheff (1987), Sowder e Harel (1998) e Rezende e Nasser (1994). Dessa forma, o professor pode, entre outras coisas, considerar ações importantes que auxiliam os alunos que apresentam provas baseadas em casos particulares a generalizarem as suas ideias, elaborando provas formais. Portanto, a formação do professor de Matemática da Educação Básica sobre argumentação e prova matemática é essencial.

Durante as atividades propostas, notamos que muitos de nossos alunos realizam argumentações com base em casos particulares, o que reitera a necessidade de estudarmos ações que visam melhorar os níveis da argumentação de nossos estudantes. Um caso que nos chamou bastante atenção foi a questão sobre as raízes de uma equação do $2^{\circ}$ grau na atividade 3 em que apresentamos um resultado que relaciona a soma e o produto das raízes com os coeficientes na equação. Como dissemos no Capítulo 6, durante as aulas não apresentamos demonstrações ou argumentos que comprovassem a verdadeira relação entre as raízes de uma equação de $2^{\circ}$ grau. Observamos que essa não é a melhor prática a ser adotada durante as aulas de Matemática, porém o objetivo era justamente o de estudar a aceitação dos alunos quanto a um resultado que aparentemente serve para qualquer equação de $2^{\underline{o}}$ grau, entretanto não fora provado. $\mathrm{O}$ fato é que nenhum aluno da turma, durante a discussão do conteúdo nas aulas regulares, demonstrou curiosidade sobre o porquê da afirmação. Os estudantes apenas utilizaram o resultado como uma verdade e aplicaram em equações particulares.

Com o decorrer das aplicações e das discussões com a turma, notamos sensível evolução em algumas argumentações dos estudantes. Os alunos, em sua maioria, ao final das atividades, percebiam a necessidade de argumentar de alguma maneira para validar as suas afirmações ou descobrir resultados.

Considerando as tipologias de Balacheff (1987), Sowder e Harel (1998) e Rezende e Nasser (1994), alguns estudantes conseguiram realizar generalizações ou ao menos elaboraram provas com conceitos genéricos, o que nos mostra a importância de atividades que tenham como objetivo melhorar o nível de argumentação de nossos alunos, tendo em vista que trabalhamos nesse intuito durante um curto período de tempo se compararmos com toda a vida escolar desses estudantes. 
Acreditamos que, como professores e pesquisadores, ao compararmos com o início de nosso trabalho, melhoramos o nosso conhecimento sobre prova matemática. Essa melhora se deu não somente na definição matemática de prova, mas principalmente do ponto de vista do ensino de Matemática.

Certamente, da mesma forma como observamos possíveis aprimoramentos de atividades desenvolvidas nesse trabalho, tanto como professores de Matemática, quanto como pesquisadores, enriqueceremos nossa prática de ensino objetivando a melhoria do nível de argumentação de nossos alunos.

Deseja-se que as atividades propostas durante a aula de Matemática possibilitem processos de generalização, elaboração de significados para expressões ou manipulações algébricas e facilite o desenvolvimento das habilidades de argumentar e provar do ponto de vista da Matemática. Segundo os trabalhos de Balacheff (1987), Sowder e Harel (1998), Nasser e Tinoco (2003) e De Villiers (2001), após as aplicações e análises de nossas atividades, visando melhorar o nível de argumentação e prova matemática, voltemos a segunda questão que norteou nosso trabalho:

- Quais os principais meios de desenvolvimento da habilidade de argumentação e prova matemática para alunos da Educação Básica?

Nesse sentido, concluímos que é importante:

- haver interação entre os alunos;

- propiciar discussões entre os resultados obtidos;

- fazer com que o estudante analise as respostas de outros alunos;

- propor questões em que o estudante sinta necessidade de verificar a veracidade da afirmação;

- estimular os testes de casos particulares e discussão sobre possíveis contradições por meio de contraexemplos;

- propor o estudo de casos particulares com o intuito de que o aluno elabore e teste conjecturas;

- propor problemas que envolvam o desenvolvimento do raciocínio lógico, mesmo sendo de conteúdos ainda não trabalhados em sala de aula; 
- elaborar questões que mostrem o perigo de usar os símbolos sem conhecer as propriedades do objeto matemático em questão.

Esses são alguns dos pontos importantes que o professor de Matemática, ao nosso ver, deve considerar para elaborar o planejamento de atividades objetivando melhorar o nível de argumentação e prova de alunos da Educação Básica.

Desde maio de 2017, trabalhamos no CAP (Centro de Aperfeiçoamento de Professores) na cidade de Barueri. Nossas atividades consistem em desenvolver materiais didáticos para todos os professores de Matemática da rede. Estamos projetando atuar com formação dos professores de Matemática que estão em serviço no município. Atualmente temos um quadro com cerca de 210 professores de Matemática. Certamente nosso conhecimento sobre prova na Matemática escolar será de grande importância durante a elaboração de nossas atividades no CAP. Dessa forma, esperamos contribuir tanto com a formação do professor, quanto, como consequência, com o conhecimento de nossos educandos no que se refere a argumentação e prova matemática.

Por fim, acreditamos que esta pesquisa, além de poder contribuir com a comunidade de professores de Matemática, nos fez aprimorar o que sabíamos sobre a prova sob o ponto de vista do ensino de Matemática. Temos o planejamento de continuar os estudos sobre argumentação e prova matemática na Educação Básica como pesquisadores, já que como professores de Matemática temos a certeza da aplicação desse conhecimento que foi e será aprimorado. 


\section{Referências bibliográficas}

ALMOUlOUD, S. A. et al. Formação de professores de Matemática e apreensão significativa de problemas envolvendo provas e demonstrações. Educação Matemática Pesquisa, São Paulo, v. 10, n.2, p. 217-243, 2008. Disponível em: <https://revistas.pucsp.br/index.php/emp/article/download/1744/1135>. Acesso em: 10 fev. 2017

ALMOULOUD, S. A.; FUSCO, C. A. S. Provas e demonstrações em matemática: uma questão problemática nas práticas docentes no ensino básico. Anais do $\mathrm{X}$ Encontro Nacional de Educação Matemática, Salvador, Bahia, 2010.

BALACHEFF, N. Aspects of proof in pupils' practice of school mathematics. In David Pimm (Ed.). Mathematics Teachers and Children. Hodder and Stoughton, London, 1988.

BALACHEFF, $\mathrm{N}$. Is argumentation an obstacle? invitation to debate... International Newsletter on the teaching and learning of Mathematical proof. Grenoble, France: Laboratoire Leibniz, Maio e junho de 1999. Disponível em: http://www.lettredelapreuve.org/OldPreuve/Newsletter/990506Theme/990506ThemeUK.html .Acesso em: 30 de maio de 2017.

BALACHEFF, N. Processus de Preuve et Situations de Validation. Educational Studies in Mathematics, 1987, v. 18, p. 147-176.

BARUERI. Prefeitura Municipal. Secretaria da Educação. Matemática $9^{\circ}$ ano $-\mathbf{1}^{\mathbf{0}}$ semestre. 2014.

BOAVIDA, A. M. A argumentação em Matemática: Investigando o trabalho de duas professoras em contexto de colaboração. 2005, 975 f. Tese ( Doutorado em Educação) Universidade de Lisboa, Portugal, 2005.

BOAVIDA, A. M. R. A argumentação na aula de Matemática: Olhares sobre o trabalho do professor. In: AMRB: XVI SIEM, Lisboa, Portugal, 2005.

BRASIL. Secretaria de Educação Fundamental. Parâmetros curriculares nacionais: Matemática / Secretaria de Educação Fundamental. Brasília: MEC / SEF, 1998.

CHARNEY, R. Aprendendo com a Resolução de Problema. Porto Alegre: Artmed, 2001.

COBB, P.; CONFREY, J.; diSESSA, A.; LEHRER, R.; \& SCHAUBLE, L. Design experiments ineducational research. Educational Researcher, v. 32, p. 9-13, 2003.

D'AMBRosio, U. Etnomatemática: elo entre as tradições e a modernidade. Belo Horizonte, MG: Autêntica, 2009.

DAVIS, P. J.; R. HERSH. Descartes’ Dream. New York: HBJ Publishers, 1986.

DE VILLIERS, M. Papel e funções da demonstração no trabalho com o Sketchpad. Revista Educação e Matemática, Lisboa, n. 63, p. 31-36, Março/Abril de 2001. 
DE VILLIERS, M. Pupils' needs for conviction and explanation within the context of geometry. Atas do PME-15, vol. 1, 255-262, Assissi, Itália, 1991.

DE VILLIERS, M. The role and function of proof in mathematics. Pythagoras, Durbanville, n. 24, p. 17-24, 1990.

FILHO, A. F. S. Desenvolvimento de uma sequência didática sobre quadriláteros e suas propriedades: contribuições de um grupo colaborativo. 2007, 165 f. Dissertação (Mestrado em Educação Matemática) Pontifícia Universidade Católica de São Paulo, São Paulo 2007.

FOSSA, J. A. Introdução às técnicas de demonstração na matemática. $2^{\mathrm{a}}$ ed. São Paulo: Livraria Da Física, 2009.

GALBRAITH, P. Aspects of proving: a clinical investigation of process Educational Studies in Mathematics, p. 1-28, 1981.

GRINKRAUT, M. L. Formação de professores envolvendo a Prova Matemática: Um olhar sobre o Desenvolvimento Profissional. 2009, 348 f. Tese (Doutorado em Educação Matemática) Pontifícia Universidade Católica de São Paulo, São Paulo 2009.

HANNA, G. Some Pedagogical Aspects of Proof. Interchange (The Ontario Institute for Studies in Education), vol 21, nº 1, p 6-13, Ontario, Canadá, 1990.

HANNA, G; JAHNKE, H. Proof and proving. Em: International Handbook of Mathematics Education, p. 877-908, 1996.

KARRER, Mônica. Articulação entre Álgebra Linear e Geometria: um estudo sobre as transformações lineares na perspectiva dos registros de representação semiótica. 2006. 300 f. Tese (Doutorado em Educação Matemática) Pontifícia Universidade Católica de São Paulo. p. 197-259, 2006.

MACHADO, N. J. Matemática e língua materna: análise de uma impregnação mútua. 3 ed. São Paulo: Cortez, 1993.

MATHEUS, A. R. Argumentação e prova na matemática escolar. 2016, 145 f. Dissertação (Mestrado) Instituto de Matemática e Estatística, Universidade de São Paulo, São Paulo, 2016.

MATIRAIN, Jacques. Elementos da Filosofia 2. A ordem dos conceitos. Lógica menor. Tradução de Ilza das Neves. Rio de Janeiro: Agir, 2001.

MORI, I.; ONAGA, D. S. Matemática: Ideias e Desafios 9º ano. São Paulo: Saraiva, 2010.

NASSER, L.; TINOCO, L. A. A. Argumentação e Provas no Ensino de Matemática. 2. ed. Rio de Janeiro: UFRJ, 2003.

PIETROPAOLO, R. (Re)significar as demonstrações nos currículos da educação básica e da formação de professores de matemática. $388 \mathrm{f}$. Tese (Doutorado em Educação Matemática) Pontifícia Universidade Católica de São Paulo (PUC SP), São Paulo, 2005.

REZENDE, J.; NASSER, L. Kinds of argumentation used in geometry. Atas do PME-18, v. 1, p. 66, Lisboa, 1994. 
SANTALÓ, L. A. Matemática para não matemáticos, in PARRA, C; SAIZ, I. (orgs). Didática da Matemática: Reflexões Psicopedagógicas. Porto Alegre: Artmed, 1996.

SOWDER, L.; HAREL, G. Types of Student's Justifications. The Mathematics Teacher. vol. 91, n. 8, p. 670-675. Estados Unidos: NCTM, 1998. 


\title{
Apêndice A
}

\section{Termo de consentimento livre e esclarecido - Escola}

\author{
TERMO DE CONSENTIMENTO LIVRE E ESCLARECIDO
}

Eu compreendo os direitos dos participantes da pesquisa intitulada Argumentação e prova matemática na educação básica, orientada por Martha Salerno Monteiro, e que tem como pesquisador responsável André Rodrigues Rosale, estudante do Instituto de Matemática e Estatística da Universidade de São Paulo, os quais podem ser contatados pelo e-mail (e-mail do pesquisador) ou telefone (telefone do pesquisador). Na qualidade de responsável pela EMEF Sandro Luiz Braga, autorizo a participação de estudantes na mencionada pesquisa e compreendo como e porque esse estudo está sendo realizado. Os responsáveis pela pesquisa garantem o sigilo, assegurando a privacidade dos sujeitos quanto aos dados envolvidos na pesquisa. Receberei uma cópia assinada deste formulário de consentimento.

Barueri , de de 2016

Nome:

Cargo e Assinatura do responsável.

Assinatura 


\title{
Apêndice B
}

\section{Termo de consentimento livre e esclarecido - responsáveis pelos alunos}

\author{
TERMO DE CONSENTIMENTO LIVRE E ESCLARECIDO
}

$\mathrm{Eu}$, RG declaro saber

da participação de meu/minha filho/a na pesquisa Argumentação e prova matemática na educação básica, desenvolvida junto ao Instituto de Matemática e Estatística da Universidade de São Paulo pelo pesquisador André Rodrigues Rosale, orientado por Martha Salerno Monteiro, os quais podem ser contatados pelo e-mail (e-mail do pesquisador) ou telefone (telefone do pesquisador). O presente trabalho tem por objetivos: desenvolver atividades que propiciem a melhora do nível da argumentação matemática de alunos da educação básica, e os instrumentos utilizados são: atividades elaboradas pelo pesquisador e aplicadas durante as aulas de matemática. Compreendo que tenho liberdade de retirar o meu consentimento em qualquer fase da pesquisa, sem penalização alguma. A qualquer momento, posso buscar maiores esclarecimentos, inclusive relativos à metodologia do trabalho. Os/as responsáveis pela pesquisa garantem o sigilo, assegurando a privacidade dos sujeitos quanto aos dados envolvidos na pesquisa. Declaro compreender que as informações obtidas só podem ser usadas para fins científicos, de acordo com a ética na pesquisa, e que essa participação não inclui nenhum tipo de pagamento.

Barueri, de de 2016

Nome:

Assinatura 